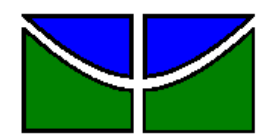

Universidade de Brasília

Faculdade de Economia, Administração, Contabilidade e Ciências da Informação e Documentação

\author{
DEPARTAMENTO DE ADMINISTRAÇÃO
}

TRABALHO DE CONCLUSÃO DE CURSO

\title{
GESTÃO DE PROJETOS DE P\&D: um estudo de caso do Sistema Embrapa de Gestão (SEG)
}

\section{Paola Bembom Garcia}




\title{
GESTÃO DE PROJETOS DE P\&D: um estudo de caso do Sistema Embrapa de Gestão (SEG)
}

\author{
Paola Bembom Garcia
}

Orientador:

\section{Prof. Dr. Eduardo Raupp de Vargas}

"Trabalho apresentado em cumprimento às exigências acadêmicas parciais da disciplina Estágio Supervisionado em administração para a obtenção do grau de Administradora" 
GARCIA, Paola Bembom

Gestão de projetos de P\&D: um estudo de caso do Sistema Embrapa de Gestão (SEG) / Paola Bembom Garcia. - 2009. 87f. : il.

Monografia (graduação) - Universidade de Brasília, Departamento de Administração, 2009.

Orientador: Prof. Dr. Eduardo Raupp de Vargas, Departamento de Administração.

1. Inovação. 2. P\&D. 3. Gestão de projetos . I. Título 
Universidade de Brasília

Faculdade de Economia, Administração, Contabilidade e Ciências da Informação e Documentação

\section{DEPARTAMENTO DE ADMINISTRAÇÃO}

\section{GESTÃO DE PROJETOS DE P\&D: um estudo de caso do Sistema Embrapa de Gestão (SEG)}

A Comissão Examinadora, abaixo identificada, aprova o Trabalho de Conclusão do Curso de Administração da Universidade de Brasília da aluna

\section{Paola Bembom Garcia}

Prof. Dr. Eduardo Raupp de Vargas

Professor-Orientador

Domingos Spezia, MSc

Professor-Examinador (Coordenador)

Brasília, 08 de julho de 2009 
Agradeço, primeiramente, à Deus, pelas bênçãos concedidas; aos meus pais, Paulo e Rosa Helena, e às minhas irmãs, Giovanna e Alessa, por sempre estarem ao meu lado incondicionalmente; aos meus avós, Fernando e Glória, por estarem sempre presentes apesar da distância; ao Vinícius, pela força e pelo companheirismo; às meninas, Amanda, Lorena e Késia, pelo compartilhamento de dúvidas e de stress; ao meu professor orientador, Eduardo Raupp, que me encorajou a fazer este trabalho; e à Embrapa, especialmente, ao Sr. Eduardo Sarmento, que possibilitou a execução deste trabalho. 


\section{RESUMO}

As inovações são os principais meios para as empresas adquirirem vantagem competitiva e gerarem desenvolvimento para o país. Porém a geração de inovações não é algo simples, pois envolve uma série de variáveis, tais como: conhecimento, disponibilidade de recursos materiais e de recursos humanos capacitados, além do contexto em que a organização está inserida, o chamado Sistema Nacional de Inovação. É por meio desse sistema que há a interação entre universidades, centros de pesquisa, empresas públicas e privadas, buscando a troca de conhecimento (principal indutor da inovação) para a decodificação das informações necessárias para a geração de produtos, processos, tecnologias ou serviços. Dentro do processo de inovação, a atividade de pesquisa e desenvolvimento (P\&D) é fator crucial, pois é por meio dela que ocorre a exploração do conhecimento para posterior solução dos problemas detectados na sociedade. Porém, essa atividade só é bem sucedida, se for bem gerenciada. A gestão de projetos de P\&D é feita geralmente por meio de um portfólio de projetos. Esse modelo de gestão possibilita a redução dos riscos envolvidos no processo de inovação, já que essa atividade envolve cenários com alto grau de incerteza, altos investimento, além do comprometimento de pessoas capacitadas por longos períodos de tempo. Devido a esse alto risco, o processo de seleção de projetos de $\mathrm{P} \& \mathrm{D}$ deve ser bem estruturado, para que a empresa não obtenha prejuízos. É baseado nesse contexto, que este trabalho busca entender o processo de gestão de projetos de P\&D dentro da principal empresa de pesquisa do país, a Embrapa. Suas pesquisas trouxeram ganhos sociais, econômicos, científicos e ambientais para o país, mostrando a importância do investimento em ciência e tecnologia. Os resultados obtidos neste trabalho são uma análise crítica do modelo de gestão de projetos de P\&D na Embrapa, principalmente da etapa de seleção dos projetos, e da atuação da Embrapa, juntamente com outros órgãos, para o desenvolvimento do país.

Palavras chave: Inovação, P\&D , Gestão de projetos, Embrapa 


\section{SUMÁRIO}

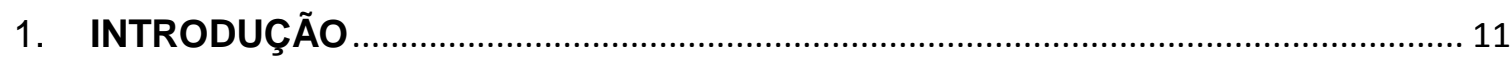

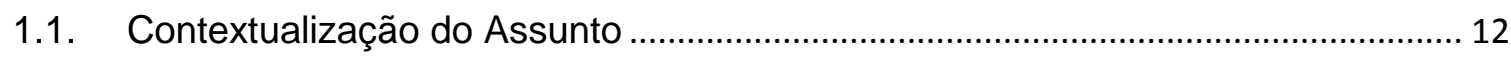

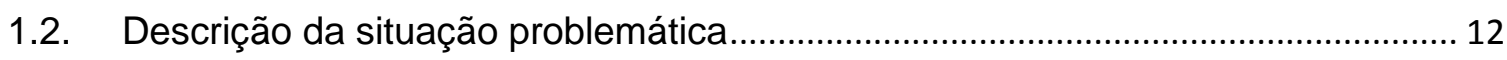

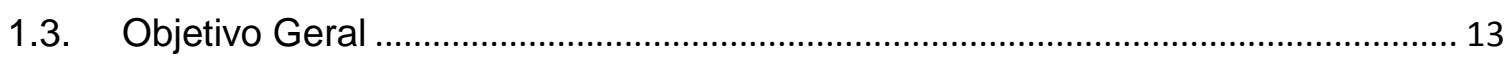

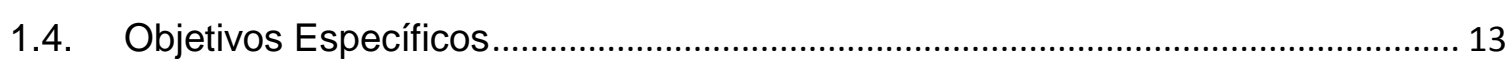

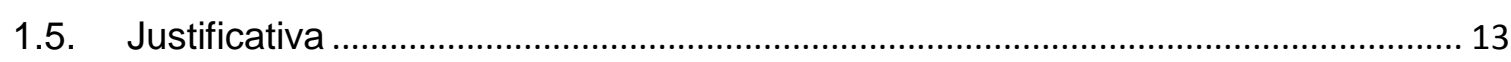

1.6. Métodos e Técnicas de Pesquisa ....................................................................... 15

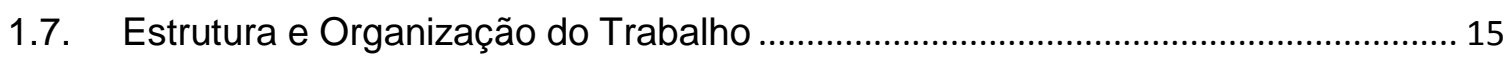

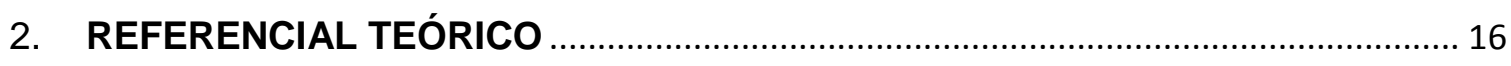

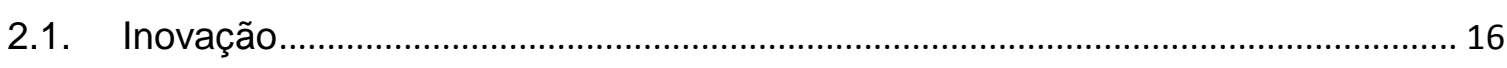

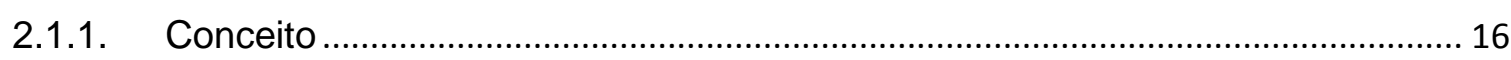

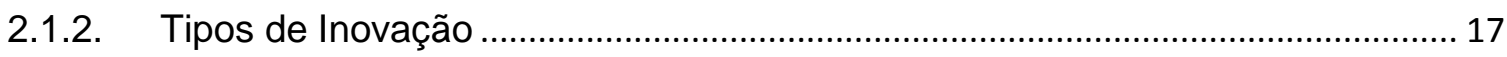

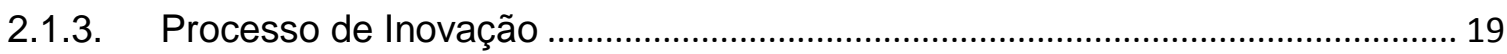

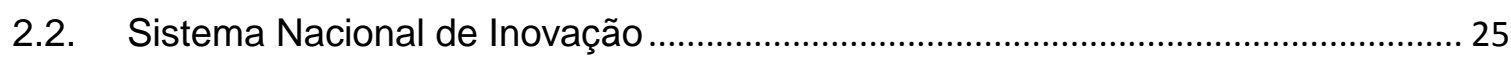

2.2.1. Evolução de Ciência e Tecnologia (C\&T) no Brasil .............................................. 25

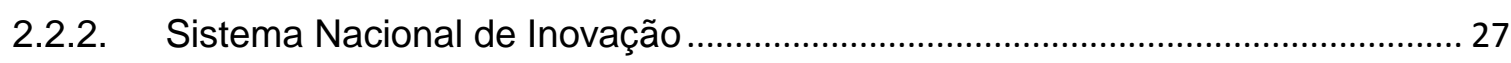

2.3. Gestão de Pesquisa e Desenvolvimento (P\&D) ..................................................... 31

2.3.1. Modelos de Inovação Tecnológica em organizações de P\&D ............................. 31

2.3.2. Gestão de Portfólio de Projetos de P\&D.................................................................. 35

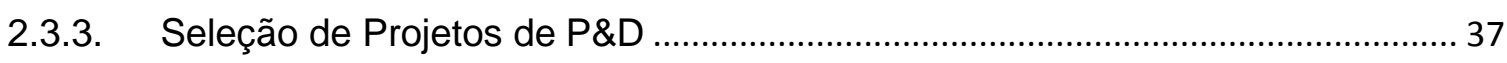

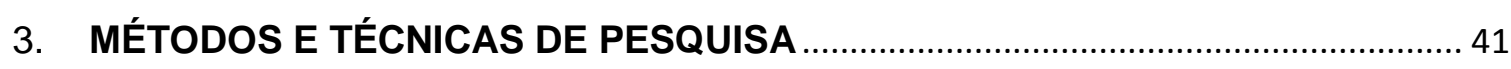

3.1. A Estratégia de Pesquisa Baseada em Estudo de Caso ........................................ 41

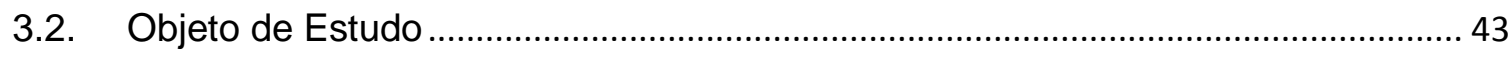

3.3. Procedimentos e instrumentos utilizados na coleta e análise dos dados ............. 44

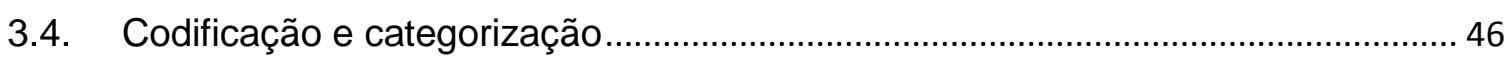

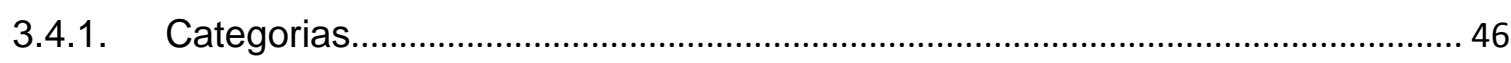

4. APRESENTAÇÃO E ANÁLISE DOS RESULTADOS DA PESQUISA .................... 48

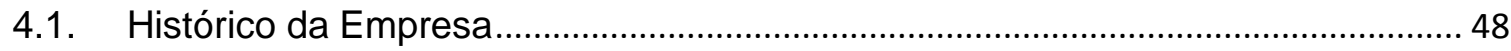

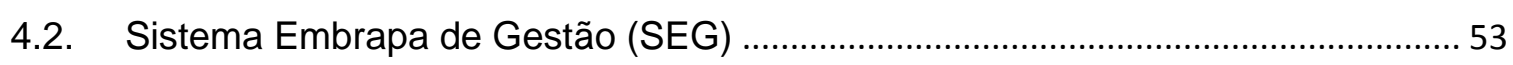

4.3. Seleção de projetos no Sistema Embrapa de Gestão (SEG) .................................. 57

4.4. Resultados do Sistema Embrapa de Gestão (SEG) ............................................. 67

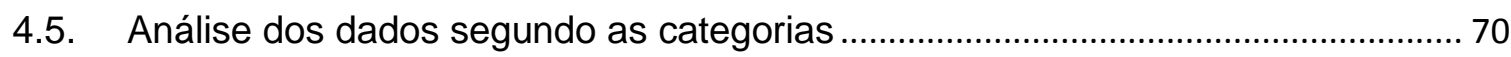

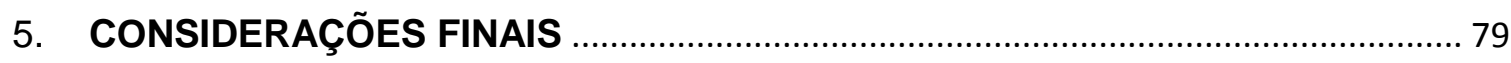

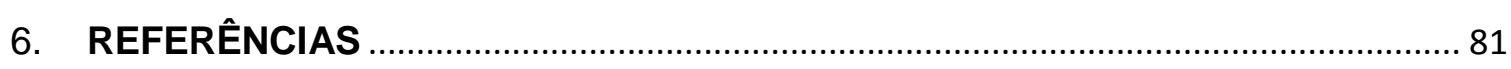




\section{LISTA DE ILUSTRAÇÕES}

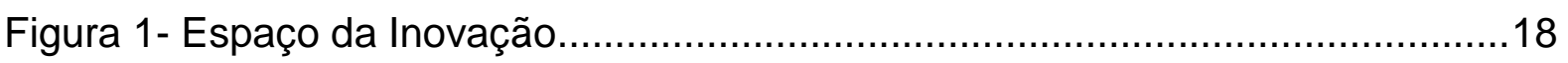

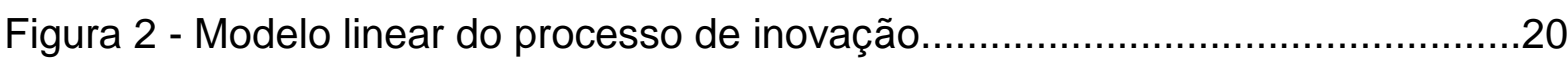

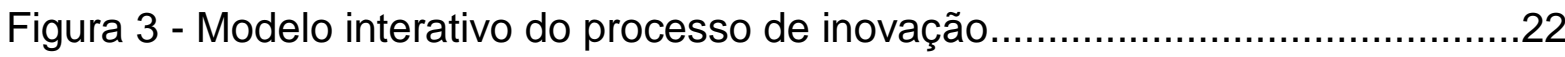

Figura 4 - Modelo sistêmico do processo de inovação...........................................23

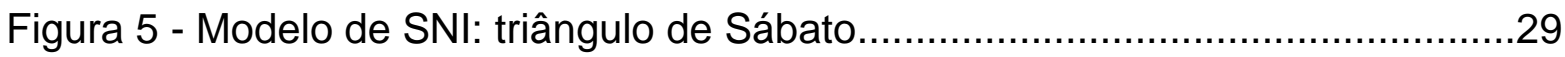

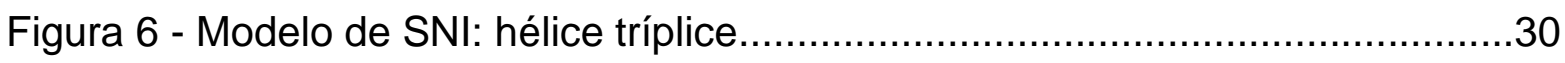

Figura 7 - Modelo de Inovação Tecnológica proposto por Amabile............................33

Figura 8 - Modelo Integrador de inovação tecnológica.........................................34

Figura 9 - Gráfico Interesse X Exequibilidade com os códigos dos projetos............40

Figura 10 - Estrutura do Sistema Embrapa de Gestão (SEG) .................................54

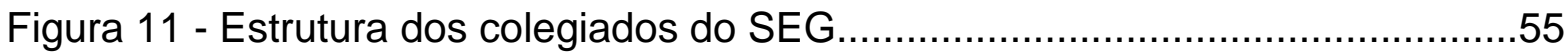

Figura 12 - Estrutura típica dos projetos do Macroprograma 1 ...............................59

Figura 13 - Estrutura típica dos projetos do Macroprograma 2..............................60

Figura 14 - Estrutura típica dos projetos do Macroprograma 3...............................60

Figura 15 - Estrutura típica dos projetos do Macroprograma 4..............................61

Figura 16 - Estrutura típica dos projetos do Macroprograma 5..............................62

Figura 17 - Estrutura típica dos projetos do Macroprograma 6.............................63

Figura 18 - Esquematização do processo de elaboração, apresentação e avaliação de pré-propostas e propostas no SEG..............................................................65 


\section{LISTA DE QUADROS}

Quadro 1 - Modelo de Inovação: principais características e indicadores................24

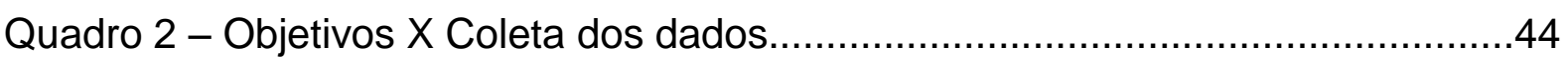

Quadro 3 - Principais regulamentações da Embrapa.........................................52

Quadro 4 - Comparação das etapas do modelo integrador com o SEG...................74

Quadro 5 - Comparação entre o modelo de gestão de portfólio de Rabechini, Maximiano e Martins com o modelo de gestão de carteira de projetos da Embrapa .75 


\section{LISTA DE TABELAS}

Tabela 1 - Recursos disponíveis por macroprograma aprovados em 2008.............68

Tabela 2 - Recursos disponíveis por macroprograma aprovados em 2008.............69

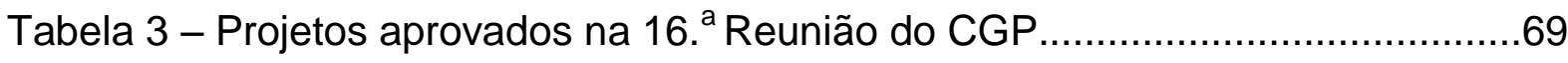

Tabela 4 - Projetos aprovados na $17 .{ }^{a}$ Reunião do CGP......................................69 


\section{LISTA DE ABREVIATURAS E SIGLAS}

C\&T - Ciência e Tecnologia

CNPq - Conselho Nacional de Desenvolvimento Científico e Tecnológico

CT\&I - ciência, tecnologia e inovação

Embrapa - Empresa Brasileira de Pesquisa Agropecuária

FINEP - Financiadora de Estudos e Projetos

MCT - Ministério da Ciência e Tecnologia

MP - macroprograma

P\&D - pesquisa e desenvolvimento

PD\&I - pesquisa, desenvolvimento e inovação

SEG - Sistema Embrapa de Gestão

SEP - Sistema Embrapa de Planejamento

SNI - Sistema Nacional de Inovação

PDE - Plano Diretor Embrapa

PDU - Plano Diretor das Unidades

DE - Diretoria Executiva

CTI - Comissão Técnica

CTMP - Comissão Técnica de Macroprogramas

CGE - Comitê Gestor da Estratégia

CGP - Comitê Gestor da Programação

CONSAD - Conselho de Administração

CAN - Conselho Assessor Nacional

SGE - Secretaria de Gestão e Estratégia 


\section{INTRODUÇÃO}

$\mathrm{Na}$ atual Era do Conhecimento, a aquisição de novas capacidades e conhecimentos é fator vital para a sobrevivência no mercado. Porém ter acesso a informações não é o suficiente. É necessário que haja conhecimento para decodificar o conteúdo da informação e transformá-la em algo que gere vantagem competitiva.

Responder às necessidades e oportunidades por meio de inovações não é simples. É preciso que haja fortes investimentos em pesquisa, desenvolvimento, educação e treinamento para possibilitar a capacitação de pessoal e transformar o conhecimento em inovação. Inovação não é apenas o surgimento de algo novo, inédito no mercado, mas é também o aprimoramento de algo que já existe. Hoje a inovação é vista como um conceito amplo de processo baseado no conhecimento, composto por várias etapas, das quais as principais são: busca, seleção e implementação (TIDD, BESSANT, PAVITT, 2008).

O processo de inovação é interativo na medida em que para que ele ocorra é necessário o acesso a diferentes tipos de informações e conhecimentos gerados por diversos agentes econômicos não se limitando ao interior das fronteiras de uma determinada organização. Assim, a interação de instituições de pesquisa, universidades, empresas públicas e privadas é de extrema importância para o surgimento de inovações que possibilitem desenvolvimento econômico, social, político e cultural da sociedade. Essa interação se dá no contexto do chamado sistema nacional de inovação, no qual instituições públicas e privadas atuam por meio de concorrência e cooperação visando à geração e difusão de conhecimento e tecnologias, fazendo da inovação e do aprendizado seus aspectos cruciais (LEMOS, 2000, p.172).

Este trabalho se debruça sobre uma das instituições que faz parte desse Sistema Nacional de Inovação e que possibilita o desenvolvimento do Brasil. A Empresa Brasileira de Pesquisa Agropecuária (Embrapa), que tem como missão viabilizar soluções de pesquisa, desenvolvimento e inovação para a sustentabilidade da agricultura, em benefício da sociedade brasileira. 


\subsection{Contextualização do Assunto}

A atividade de pesquisa e desenvolvimento (P\&D) é de extrema importância para a geração de inovações. É por meio dessa atividade que ocorre a exploração de conhecimento e a geração de soluções para os problemas detectados na sociedade. Essa atividade, além de contribuir para o desenvolvimento da sociedade, também contribui para a sustentabilidade das empresas, pois gera vantagem competitiva.

São inúmeros os problemas que demandam inovações, porém não há recursos, tanto materiais quanto humanos, para desenvolver soluções para todos. Assim, as empresas atuantes nessa área precisam selecionar os problemas mais relevantes e que possuem viabilidade para serem solucionados. Por isso, a importância da gestão da inovação, mais especificamente das atividades de P\&D.

A seleção de projetos de $P \& D$, assim como as outras etapas envolvidas nesse processo, envolve cenários com alto grau de incertezas, riscos e investimentos. Mas, juntamente com esses fatores críticos, existem as recompensas, que podem ser altíssimas tanto para a empresa (adquire conhecimento, vantagem competitiva e lucro), quanto para a sociedade (melhor qualidade de vida). Assim, a melhor forma das empresas lidarem com isso, é tendo um método estruturado de seleção de projetos.

Tendo em vista os aspectos explicitados acima, o presente trabalho se propõe a entender como ocorre o processo de seleção de projetos de P\&D em uma das empresas mais importantes da área, a Empresa Brasileira de Pesquisa Agropecuária (Embrapa).

\subsection{Descrição da situação problemática}

Os projetos de inovação tecnológica ganharam impulso dentro do setor agropecuário, tendo em vista as transformações ocorridas nos últimos anos, tais como: a mudança climática global e a maior preocupação com a sustentabilidade ambiental. Para atender a todos esses aspectos emergentes de pesquisa, é necessário que haja um bom gerenciamento de projetos de pesquisa e desenvolvimento (P\&D). Assim o problema em questão é saber como a Empresa 
Brasileira de Pesquisa Agropecuária (Embrapa) seleciona os projetos de P\&D que serão desenvolvidos pela empresa?

\subsection{Objetivo Geral}

Entender como é feito o processo de seleção de projetos de P\&D identificando as variáveis consideradas para a escolha das trajetórias tecnológicas mais promissoras dos projetos a serem desenvolvidos pela Empresa Brasileira de Pesquisa Agropecuária (Embrapa).

\subsection{Objetivos Específicos}

- Identificar os principais modelos de P\&D presentes na literatura da área, focando na etapa de seleção dos projetos

- Caracterizar o modelo de P\&D implementado na Empresa Brasileira de Pesquisa Agropecuária (Embrapa), focando na etapa de seleção de projetos de P\&D

- Analisar o processo de escolha de projetos de P\&D a serem desenvolvidos pela Embrapa, juntamente com suas parceiras

\subsection{Justificativa}

A preocupação com a sustentabilidade ambiental é cada vez mais forte. Por isso, esse aspecto se tornou um dos mais importantes temas da agenda de inovação das empresas. Dentre os vários aspectos que justificam este fato estão: aquecimento global e suas conseqüentes ameaças, poluição ambiental, diminuição das fontes de energia esgotáveis e maior preocupação com a saúde.

Os desafios gerados por esse problema mundial são grandes oportunidades de inovação. Esta pode ser percebida tanto em produtos sustentáveis, tal como os sistemas de energia solar; como em processos, como é o caso de processamento eletrônico ao invés do físico; e possibilita até a abertura de novos mercados, que é o caso dos alimentos orgânicos e do ecoturismo. 
Com base nesse cenário, a empresa escolhida para ser estudada foi a Empresa Brasileira de Pesquisa Agropecuária, a Embrapa. Esta empresa, juntamente com outras organizações, tais como Ministério da Ciência e Tecnologia (MCT), Conselho Nacional de Desenvolvimento Científico e Tecnológico (CNPq), Financiadora de Estudos e Projetos (FINEP), que também são órgãos do Governo Federal; universidades, instituições de pesquisa e empresas privadas, é responsável pelo atual estágio de desenvolvimento do sistema produtivo agropecuário nacional.

A chegada a esse estágio só foi possível devido ao grande investimento em pesquisa, desenvolvimento e inovação. O conhecimento gerado proporcionou grandes mudanças no cenário da agropecuária brasileira, trazendo ganhos sociais, econômicos e ambientais para o país. Hoje o problema não é mais produzir alimentos e sim produzi-los com melhor qualidade, com maior eficiência e com os menores danos ambientais possíveis, para manter sua competitividade internacional.

São vários os desafios que podem ser explorados. A Embrapa atua com um portfólio de projetos de P\&D, tratando de assuntos como: competitividade e sustentabilidade, desenvolvimento tecnológico incremental para o agronegócio, desenvolvimento institucional, apoio ao desenvolvimento da agricultura familiar e à sustentabilidade do meio rural.

As inovações ligadas a fatores de sustentabilidade possuem implicações sistêmicas e, portanto, necessitam de um gerenciamento integrado e de alta qualidade. Isso ocorre porque esse tipo de inovação surge de preocupações com o ambiente social, político, cultural e econômico e oferecem alto risco de fracasso se os elementos de demanda forem desconsiderados. Por isso é importante saber o que vem pela frente, tentando se antecipar aos problemas de forma segura. E para que isso ocorra de maneira eficiente é necessário que haja uma gestão de projetos de P\&D integrada e atenta aos cenários prospectados.

Esse trabalho visa apresentar o modelo bem sucedido de gestão de P\&D, focando na parte de seleção de projetos a serem desenvolvidos pela Empresa Brasileira de Pesquisa Agropecuária (Embrapa). O modelo apresentado poderá ser utilizado por outras empresas, contanto que seja adaptado a realidade de cada organização. 


\subsection{Métodos e Técnicas de Pesquisa}

A pesquisa foi feita utilizando a estratégia de estudo de caso. A coleta de dados ocorreu por meio de entrevistas abertas e análise documental, além da revisão de literatura a respeito do tema. Quanto a análise de dados, ela ocorreu baseando-se em proposições teóricas, utilizando a técnica proposta por Yin (2005) de adequação ao padrão. Essa técnica fundamenta-se na comparação entre o modelo padrão e a base prognóstica, permitindo assim a crítica aos resultados obtidos.

\subsection{Estrutura e Organização do Trabalho}

O presente trabalho busca entender como ocorre o processo de seleção de projetos de P\&D na Empresa Brasileira de Pesquisa Agropecuária (Embrapa). Para dar consistência a essa pesquisa, o referencial teórico utilizado é composto por três capítulos. O primeiro capítulo discorre sobre a inovação, seus conceitos, seus tipos e sua importância. Em seguida são discutidos aspectos relacionados à Ciência e Tecnologia (C\&T) no Brasil e Sistema Nacional de Inovação. O terceiro capítulo aborda aspectos sobre a gestão de pesquisa e desenvolvimento (P\&D), falando desde os modelos de inovação tecnológica até as técnicas utilizadas para a seleção de projetos de $\mathrm{P} \& \mathrm{D}$.

A próxima parte do estudo corresponde à metodologia de pesquisa utilizada. O capítulo aborda aspectos sobre a utilização do estudo de caso como estratégia de pesquisa, o objeto de pesquisa e a forma de coleta dos dados. O próximo capítulo apresenta a descrição dos dados, com posterior análise desse segundo as categorias estipuladas.

A última parte do trabalho é composta pela conclusão, onde é feito um resumo do trabalho, juntamente com algumas reflexões sobre o tema apresentado. 


\section{REFERENCIAL TEÓRICO}

Este capítulo será dedicado à apresentar o referencial teórico utilizado como base para a presente pesquisa. Nele será abordado aspectos relevantes do processo de inovação que é um dos responsáveis pelo desenvolvimento gerado para o país. Temas como inovação, sistema nacional de inovação e gestão de projetos de pesquisa e desenvolvimento (P\&D) serão abordados nas seções seguintes.

\subsection{Inovação}

Esta seção é dedicada a apresentar aspectos relevantes para o entendimento teórico sobre inovação. Assim, serão encontrados a seguir assuntos como: conceito de inovação, tipos de inovação e processo de inovação.

\subsubsection{Conceito}

A inovação hoje é tida como a fonte de vantagem competitiva das empresas, e, portanto, é a fonte de sua sobrevivência no mercado e de sua lucratividade. Definir inovação não é simples. Muitas vezes inovação é confundida com invenção.

Segundo Joseph Schumpeter, que é tido como o pai dessa área da teoria econômica sendo sua obra considerada um marco no estudo sobre inovações, a invenção não produz nenhum efeito economicamente relevante, fato que ocorre com a inovação. Para Tidd, Bessant e Pavitt (2008), a inovação é o processo de fazer de uma oportunidade uma nova idéia e de colocá-la em uso da maneira mais ampla possível, ou seja, é tendo em vista uma necessidade, ter uma idéia e colocá-la em prática, podendo avaliar seus resultados.

Barbieri e Simantob (2007) definem inovação como a união de três fatores: idéia, implementação e resultados. Por idéia entende-se todo tipo de conhecimento, informação, sugestão que gere uma concepção de algo concreto ou abstrato. Implementação corresponde a ação, realização, ou seja, fazer acontecer aquilo que antes era apenas um plano mental. E resultados são os efeitos esperados, tangíveis ou intangíveis, que não aconteceriam espontaneamente. 
Segundo esses autores, as inovações podem ser vistas como fatos econômicos, técnicos, organizacionais e culturais. Econômicos porque envolvem alocação de recursos escassos e dependem da aceitação de mercado, ou seja, de uma forma ou de outra são influenciados pela sociedade. São técnicos, pois envolvem ampliação de conhecimentos e objetivos a serem alcançados. São organizacionais, posto que envolvem pessoas, recursos e processos administrativos para a sua realização. E são culturais porque envolvem crenças, valores, interesses dos grupos sociais que a concebem, apóiam, implementam e utilizam. Assim, a inovação pode ser vista como um processo interativo e baseado no conhecimento composto de várias etapas, das quais se destacam a seleção, implementação e avaliação.

\subsubsection{Tipos de Inovação}

As inovações geram mudanças em diversas áreas do conhecimento. Tendo esse aspecto em vista, Tidd, Bessant e Pavitt (2008) classificam a inovação em quatro categorias, os chamados 4P's da inovação:

- Inovação de produto: que seriam mudanças nos produtos ou nos serviços que a empresa oferece;

- Inovação de processo: que seriam mudanças na forma em que os produtos ou serviços são criados;

- Inovação de posição: que seriam mudanças no contexto em que os produtos ou serviços são induzidos;

- Inovação de paradigma: que seriam mudanças nos modelos mentais que orientam o que a empresa faz.

A inovação de produto é, por exemplo, um novo modelo de automóvel ou uma nova forma de oferecer um serviço. Já a inovação de processo é, por exemplo, a mudança na matéria-prima utilizada para fabricar determinado produto. A inovação de posição é mais abrangente, um exemplo é a contribuição de Henry Ford, que com seu motor a combustão e com seu processo de linha de montagem fez com que os carros se popularizassem. O que antes era consumido apenas pelos mais abastados, passou a ser disponível a qualquer cidadão a um preço que eles podiam pagar. E finalmente a inovação de paradigma, que é, por exemplo, a introdução dos 
serviços financeiros pela Internet, que gerou além de redução de custos, aumento da qualidade e da rapidez com que o serviço é prestado.

Outra forma de classificar a inovação é tendo como base o grau de novidade envolvido. Freeman (1988 apud LEMOS, 2000) classifica as inovações em incremental e radical. As inovações incrementais são aquelas que introduzem qualquer tipo de melhoria no produto ou no processo. Possui menos riscos, já que há algum conhecimento prévio do cenário em que estão inseridas, e segundo estudos (TIDD, BESSANT e PAVITT, 2008, p.31), ela resulta em ganhos de eficiência maiores a longo prazo do que os proporcionados pelas inovações radicais. As melhorias em automóveis, por exemplo, são consideradas como inovação incremental. Já as inovações tidas como radicais são aquelas que apresentam algo inédito no mercado até aquele momento, portanto representa uma ruptura no padrão tecnológico anterior. Elas possuem altos riscos, pois exigem um processo de exploração de conhecimento em ambientes de grande incerteza. Um exemplo desse tipo de inovação foi a introdução da máquina a vapor no final do século XVIII. A introdução dessa inovação mudou todo o processo de produção das empresas.

Tidd, Bessant e Pavitt (2008) definem a inovação incremental como "fazendo o que sabemos, mas melhor" e a inovação radical como "fazer de um jeito diferente". A figura 1 mostra o espaço potencial de inovação onde a empresa pode operar, ou seja, a mudança pode ocorrer ao longo de qualquer um dos 4P's, desde a mudança incremental até a radical.

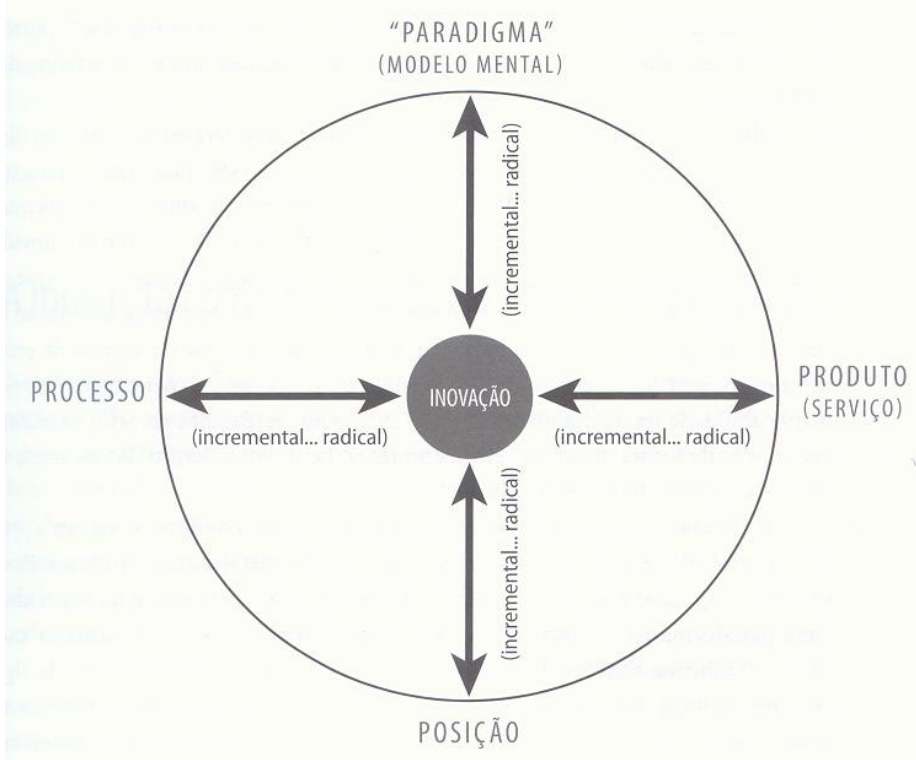

Figura 1 - Espaço da Inovação

Fonte: Tidd, Bessant e Pavitt (2008), p.33 
Damanpour (1991 apud MOREIRA, QUEIROZ, 2007) acrescenta mais uma medida para classificar as inovações. Segundo ele, existem duas classificações para as inovações, cada uma dessas possuindo um par de categorias. Além de classificar as inovações considerando o foco (produto ou processo, que são as únicas medidas consideradas por ele) e o grau de inovação (radical ou incremental), ele as classifica em tecnológicas ou técnicas e administrativas. As inovações tecnológicas ou técnicas seriam aquelas que envolvem às atividades operacionais e podem se referir tanto a produtos como a processos de produção. Já as inovações administrativas seriam aquelas que envolvem a estrutura organizacional e os processos administrativos da empresa.

\subsubsection{Processo de Inovação}

Pelo fato de a inovação ser um processo, vários modelos foram explicitados como tentativa de gerenciar a inovação. Esses modelos buscam explicar as relações entre ciência, tecnologia e inovação, entre si mesmos, e com o resto da sociedade, da economia e do ambiente. Assim, esses modelos são fatores importantes para o desenvolvimento de indicadores de ciência, tecnologia e inovação (CT\&I).

O primeiro modelo criado foi o chamado modelo linear de inovação ou science push. Esse modelo propunha que o processo de inovação era um processo linear, ou seja, a inovação era produto de uma seqüência de etapas pré-definidas e sem nenhuma influência do meio externo ou interno a organização. O processo de inovação se iniciaria com a pesquisa básica. Em seguida teríamos a pesquisa aplicada, posteriormente o desenvolvimento experimental e por último haveria a incorporação desse conhecimento adquirido à produção, para a comercialização do produto.

A figura 2 representa as etapas do modelo linear do processo de inovação citadas acima. 


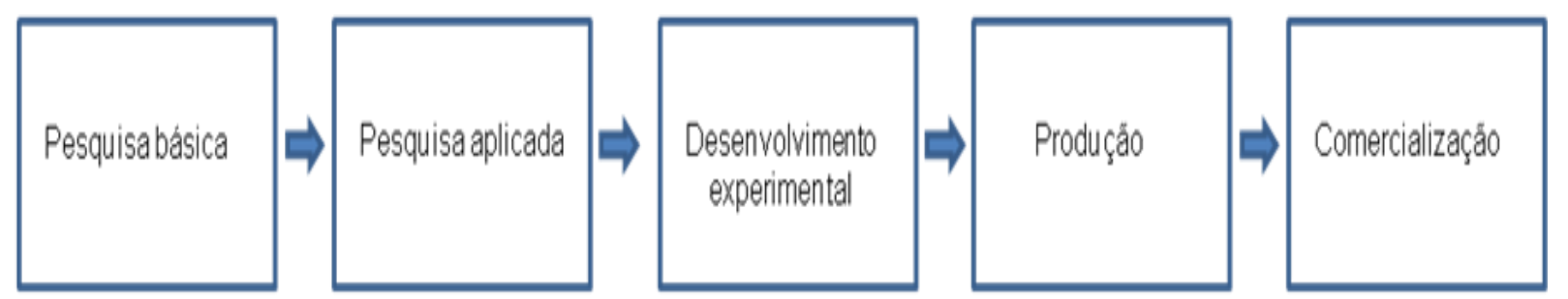

Instituiçóes/Laboratórios de pesquisa

(Oferta de tecnologias)

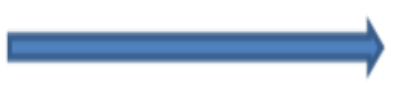

Empresas

(Demandade tecnologias)

Figura 2 - Modelo Linear do processo de inovação

Fonte: Viotti e Macedo (2003), p.55 adaptado pela autora

Segundo o Manual de Frascati (VIOTTI, MACEDO, 2003) a pesquisa básica é o trabalho teórico e experimental voltado para a aquisição de conhecimento, sem visar nenhuma aplicação desse. Esta última aplicação corresponde a pesquisa aplicada, ou seja, esta visa a aplicação prática do conhecimento. Já o desenvolvimento experimental é conceituado como o trabalho sistemático baseado em conhecimento existente, o qual foi fruto de pesquisa e de experiência prática, voltado para a produção de novos produtos, processos, serviços ou para melhorar algo já existente.

De acordo com esse modelo, o investimento pesado em ciência gera um estoque de conhecimento científico no país, o qual é utilizado pelas empresas no desenvolvimento de novos produtos e processos, com conseqüente geração de riqueza e desenvolvimento econômico-social do país (Viotti e Macedo, 2003; Barbieri e Álvares, 2003 apud MOREIRA, QUEIROZ, 2007).

Moreira e Queiroz (2007) colocam que existe também o modelo linear reverso ou demand pull. Esse modelo segue as mesmas premissas no modelo linear (science push), com a única diferença de que nesse, a inovação é estimulada pelas necessidades do mercado ou por problemas operacionais da empresa.

Viotti e Macedo (2003) explicam que esse modelo tem alta aceitação entre as comunidades de pesquisadores, pois "justifica a concessão pelo Estado de recursos crescentes para a pesquisa, sem a necessidade de haver maiores considerações sobre sua eventual aplicabilidade". Assim, as políticas de Ciência e Tecnologia (C\&T) seriam voltadas essencialmente para a elevação de concessões de recursos a pesquisadores e instituições de pesquisa, já que o modelo propõe que quanto 
mais insumos, sejam eles humanos, materiais ou financeiros; alocados na pesquisa básica, maior será a produção de invenções e inovações.

Com base nisso, os indicadores de C\&T para esse modelo são relacionados ao dispêndio em atividades de pesquisa e desenvolvimento (P\&D), que são vistos como uma forma de medir os insumos utilizados no processo de produção de inovações; e os indicadores de patentes, que são tidos como índice do resultado do processo de geração de inovação (VIOTTI, MACEDO, 2003).

Com o passar dos anos, estudiosos do fenômeno da inovação começaram a criticar o modelo linear. A principal crítica sofrida por esse modelo é relativa ao "processo de inovação como um fenômeno compartimentalizado e seqüencial, no qual a empresa desempenha basicamente o papel de uma simples usuária da tecnologia" (VIOTTI, MACEDO, 2003).

O modelo criado para suprir essa falha foi o chamado modelo elo de cadeia ou chain-linked model. Nele, o processo de inovação é tido como complexo, interativo e não-linear. Esse modelo enfatiza que a inovação é produto de um processo de interação entre oportunidades de mercado e a base de conhecimentos e capacitações da organização. Propõe também que ocorrem retroalimentações (feedbacks) ao longo do processo, sendo possível o retorno a etapas anteriores para o aperfeiçoamento ou para a solução de problemas surgidos ao longo do processo. Com isso, a empresa é colocada no centro do processo de inovação, e a pesquisa é vista como uma forma de resolver problemas surgidos em qualquer das etapas desse processo, e não como a única fonte de idéias (VIOTTI, MACEDO, 2003). 


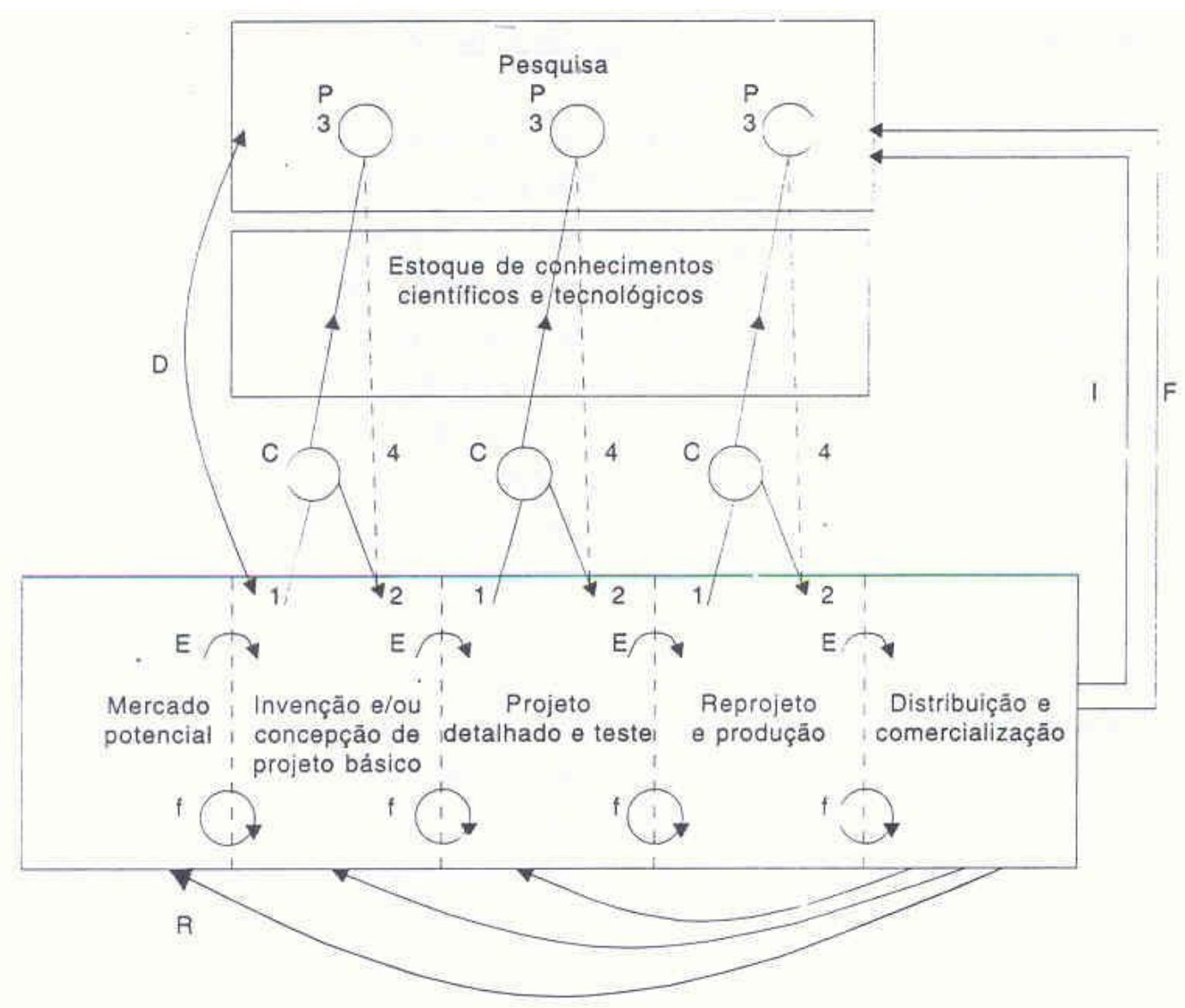

Firmas individuais e setores produtivos em um nivel mais agregado

Figura 3 - Modelo interativo do processo de inovação Fonte: Viotti e Macedo (2003), p.58

Smith (apud VIOTTI, MACEDO, 2003, p.59) enfatiza três aspectos básicos da inovação vista com base no modelo elo de cadeia. São eles:

- a inovação não é um processo seqüencial, pois envolve várias interações e realimentações;

- a inovação envolve insumos multifacetados;

- a inovação não depende de processos de invenção, ou seja, de descoberta de novos princípios; e os processos de P\&D devem ser realizados para a solução de problemas durante o processo de inovação, e não para iniciá-lo.

As políticas de C\&T inspiradas por esse modelo são voltadas para 0 fortalecimento da capacitação tecnológica das empresas e de suas relações com as 
instituições de pesquisa, pois o modelo elo de cadeia coloca a empresa e sua base de conhecimento no centro do processo de inovação.

Estudos mais recentes caracterizam o processo de inovação de acordo com a abordagem de sistema nacional de inovação. Essa abordagem surgiu devido aos esforços para explicar por que alguns países apresentam processos de desenvolvimento tecnológico e econômico superior ao de outros. Com base nisso, surge o conceito do modelo sistêmico de inovação.

O modelo sistêmico de inovação propõe que as empresas não inovam isoladamente, mas sim em um contexto de um sistema de redes de relações diretas e indiretas com outras empresas, sendo elas entidades de pesquisa, universidades, Governo e empresas públicas e privadas; com a economia nacional e internacional e com o sistema normativo vigente (VIOTTI, MACEDO, 2003). Esse modelo é representado na figura 4 , localizada abaixo.

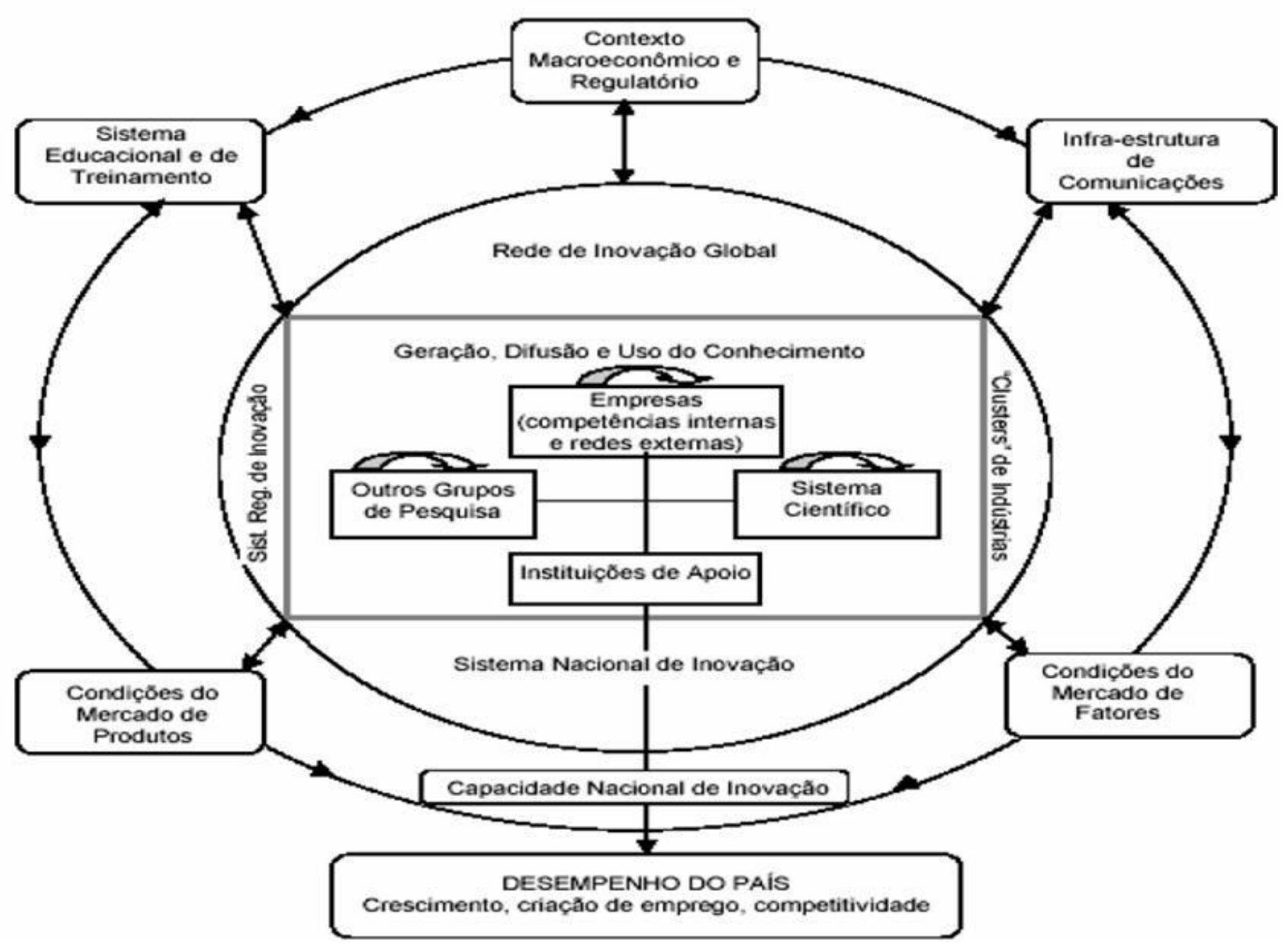

Figura 4 - Modelo Sistêmico do processo de inovação Fonte: Viotti e Macedo (2003), p.61 adaptado da OCDE 
Os indicadores de C\&T desse modelo buscam identificar as características de funcionamento de cada sistema nacional de inovação, principalmente suas deficiências, para superá-las com esforços em políticas públicas e estratégias organizacionais. Assim, os indicadores de C\&T buscam mensurar o fluxo de recursos humanos, informações e conhecimentos, fazer o mapeamento institucional dos sistemas nacionais de inovação e do comportamento inovador de suas empresas. O quadro 1 abaixo resume as principais características e indicadores de cada um dos modelos de inovação citados.

\begin{tabular}{|c|c|c|c|}
\hline Modelo & Linear & Elo de cadeia & Sistêmico \\
\hline Agente principal & $\begin{array}{l}\text { Instituições de } \\
\text { pesquisa ou } \\
\text { laboratórios }\end{array}$ & Empresas & $\begin{array}{l}\text { Empresas em interação com instituições do } \\
\text { sistema de inovação }\end{array}$ \\
\hline $\begin{array}{l}\text { Natureza do } \\
\text { processo de } \\
\text { inovação }\end{array}$ & $\begin{array}{l}\text { Inovação como um } \\
\text { fenômeno ocasional }\end{array}$ & $\begin{array}{l}\text { Inovação como um processo } \\
\text { contínuo e interativo (inovação } \\
\text { incremental) }\end{array}$ & Inovação como um processo social e sistêmico \\
\hline $\begin{array}{l}\text { Posição relativa } \\
\text { da pesquisa }\end{array}$ & $\begin{array}{l}\text { A pesquisa precede } \\
\text { a inovação, gera as } \\
\text { invenções e estas } \\
\text { são transformadas } \\
\text { em inovações }\end{array}$ & $\begin{array}{l}\text { A pesquisa não é vista como a } \\
\text { fonte das idéias inventivas, mas } \\
\text { sim como uma forma de } \\
\text { resolver problemas surgidos em } \\
\text { qualquer das etapas do } \\
\text { desenvolvimento da inovação }\end{array}$ & $\begin{array}{l}\text { A pesquisa é apenas uma atividade em um } \\
\text { conjunto maior de determinantes da inovação, no } \\
\text { qual se destacam as interações e interfaces entre } \\
\text { vários atores e instituições, assim como o } \\
\text { funcionamento do sistema como um todo, em vez } \\
\text { do desempenho de seus componentes individuais }\end{array}$ \\
\hline \multirow{4}{*}{$\begin{array}{l}\text { Relação entre os } \\
\text { elementos da } \\
\text { mudança técnica }\end{array}$} & Invenção & & Invenção \\
\hline & Inovação & & Inovação \\
\hline & Difusão & & Difusão \\
\hline & Inovação incremental & \multicolumn{2}{|r|}{ Inovação incremental } \\
\hline $\begin{array}{c}\text { Natureza da } \\
\text { tecnologia }\end{array}$ & Codificável & \multicolumn{2}{|r|}{ Codificável e tácita } \\
\hline $\begin{array}{l}\text { Relação da firma } \\
\text { com a tecnologia }\end{array}$ & $\begin{array}{c}\text { Consumidora de } \\
\text { tecnologia }\end{array}$ & \multicolumn{2}{|c|}{ Produtora e absorvedora de tecnologia } \\
\hline \multirow{3}{*}{$\begin{array}{l}\text { Indicadores de } \\
\text { inovação típicos }\end{array}$} & Dispêndios em P\&D & Surveys de inovação & Indicadores de fluxo de conhecimento \\
\hline & Patentes & & Mapeamentos institucionais \\
\hline & & & $\begin{array}{l}\text { A integração desses vários tipos de indicadores, } \\
\text { inclusive os de natureza socioeconômica }\end{array}$ \\
\hline
\end{tabular}

Quadro 1 - Modelos de inovação: principais características e indicadores

Fonte: Viotti e Macedo (2003), p.63 


\subsection{Sistema Nacional de Inovação}

Essa seção é dedicada a enfatizar a importância da Ciência e Tecnologia para o desenvolvimento do país e conceituar Sistema Nacional de Inovação, o qual tem papel importante na geração de inovações e de conhecimento.

\subsubsection{Evolução de Ciência e Tecnologia (C\&T) no Brasil}

Ciência e Tecnologia são dois aspectos essenciais de uma política efetiva de desenvolvimento nacional. Sua importância é tão marcante, que segundo Zouian (2001), ela marca a divisão do mundo em duas civilizações. A primeira civilização é onde a ciência é considerada como a principal atividade geradora de conhecimento. É onde se observa uma rápida evolução das tecnologias e a incorporação destas nos processos produtivos e sociais, e onde o aparecimento de novas formas de trabalho e vida são profundamente influenciados pela moderna ciência e suas tecnologias. Já a segunda civilização é caracterizada pela falta de capacidade de gerar conhecimentos científicos em larga escala e pela aceitação passiva dos resultados científicos gerados pela primeira. Possui um sistema produtivo que é dependente da expansão da produção das nações industrializadas e da absorção da tecnologia importada, o que faz com que a infra-estrutura tecnológica seja freqüentemente estagnada.

Ferreira, 1977 (apud ZOUIAN, 2001, p.19) ressalta o fato de que o conjunto de instituições e mecanismos financeiros formadores do Sistema Nacional de C\&T tem três objetivos interdependentes. O primeiro deles se refere à política ligada ao desenvolvimento econômico do país. O segundo refere-se à política tecnológica ligada especificamente ao desenvolvimento social. E o terceiro diz respeito ao desenvolvimento científico, implicando desenvolvimento e fortalecimento da capacidade de pesquisa e absorção de novos conhecimentos.

No Brasil, a busca por um desenvolvimento tecnológico se inicia em conseqüência da expansão das fronteiras de mercado dos países desenvolvidos. A necessidade de distribuir os custos dos investimentos que haviam sustentado a aceleração do progresso técnico desses países gera a busca por terras férteis a incorporação de tendências de internacionalização da época. 
Brasil, devido à rapidez com que foi o processo de industrialização, estava propenso a essa tendência de internacionalização. Assim, a tecnologia necessária para garantir o funcionamento das empresas brasileiras foi buscada no exterior, pois havia falta de know-how no país. Inicialmente havia apenas a incorporação de imigrantes qualificados ao processo produtivo para a formação de recursos humanos no país. Em seguida, o país começou a recorrer a contratos de transferência de tecnologia que permitissem a incorporação efetiva de conhecimento.

A primeira tentativa de incentivar a inovação no país ocorreu no final da década de 60, quando modificações no cenário internacional diminuíram o ritmo das inovações nos países desenvolvidos. Isso fez com que os países subdesenvolvidos buscassem meios de inovar, já que a oferta de tecnologia estava cada vez mais competitiva. A instituição do Programa Estratégico de Desenvolvimento (PED) deu início a política de desenvolvimento científico e tecnológico brasileiro. A partir daí o governo criou planos e políticas específicas para a área, agências de fomento (FINEP), bancos de investimento (BNDES, por exemplo) e cursos de pósgraduação.

A busca por um modelo de pesquisa e desenvolvimento e inovação para atender as necessidades do Brasil ocorreu na década de 70. As principais necessidades que deveriam ser atendidas era o aumento na eficiência produtiva, na quantidade e na qualidade dos alimentos e na produção de produtos geradores de divisas. Algumas ações tomadas pelo Governo para possibilitar essa política foram a criação do Ministério de Ciência e Tecnologia (MCT) e a criação da Empresa Brasileira de Pesquisa Agropecuária (Embrapa), em 1973.

Barbieri e Simantob (2007, p.10) colocam que o modelo de inovação escolhido para servir como base foi o modelo linear de inovação, ou science push. Como foi dito no capítulo anterior, esse modelo considera que o investimento pesado em ciência gera um estoque de conhecimento científico no país, o qual será utilizado pelas empresas no desenvolvimento de novos produtos e processos, gerando riqueza, e posteriormente, desenvolvimento social.

A partir dos anos 90, o país fez a opção por implantar e desenvolver uma estrutura científica e tecnológica capaz de garantir um aprendizado de forma contínua, transformando, cotidianamente, conhecimento em inovação e inovação em desenvolvimento. A abertura do mercado fez com que as empresas começassem a dá a devida importância ao setor de P\&D e inovação. Algumas medidas foram 
implementadas pelo Governo, tais como: aumento do financiamento industrial e estabelecimento de programas governamentais para estimular a qualidade e competitividade das indústrias. Porém não bastava apenas investir em políticas de inovação, a sociedade brasileira também precisava mudar a sua postura diante da inovação.

Atualmente, a percepção de ciência e tecnologia no Brasil é muito boa. É o que afirma uma pesquisa de Voight e Polino (apud BARBIERI; SIMANTOB, 2007, p. 90) sobre a percepção pública de ciência realizada em 2003. De acordo com essa pesquisa, os brasileiros têm uma imagem positiva da ciência e tecnologia e atribuem a elas o principal motivo de qualidade de vida da sociedade, porém admitem que elas não são a solução para qualquer problema. Isso mostra um descompasso entre os investimentos em C\&T pelo governo e a importância dada pela sociedade a esse aspecto.

\subsubsection{Sistema Nacional de Inovação}

Bessant, Tidd e Pavitt (2008) colocam que existem dois aspectos no cenário empresarial que exercem grande influência estratégica na inovação das organizações. O primeiro deles é o sistema nacional de inovação e o segundo é a posição ocupada pela empresa no mercado comparada às suas concorrentes.

O Sistema Nacional de Inovação (SNI) é definido por Freeman e Nelson (apud BARBIERI; SIMANTOB, 2007, p. 14) como uma construção institucional, que pode ser produto de uma ação planejada e consciente, ou de um somatório de decisões não planejadas e desarticuladas, que impulsiona o progresso tecnológico em economias capitalistas complexas.

Pavitt e Patel (1994 apud BARBIERI; SIMANTOB, 2007, p.14) complementam esse conceito, tornando-o mais abrangente. Para eles, SNI é uma rede de instituições, tanto públicas quanto privadas, cujas atividades e interações iniciam, importam, modificam e difundem novas tecnologias.

A maneira como o SNI se manifesta é diferente em cada país, pois depende do modo como se trata as universidades, centros de pesquisa e empresas. Todos esses agentes interagem e possuem um destino comum, porém não se pode desconsiderar que existem fronteiras entre eles. Assim, cada um dos agentes de um 
SNI possui funções. Às empresas compete prover os produtos e serviços de que a sociedade necessita, com qualidade e em condições econômica e eticamente aceitáveis. Às universidades cabem a missão de educar, formar pessoal, pesquisar e buscar conhecimento. Quanto aos institutos de pesquisa há distinção em relação a sua função. Podem ser mais ligados ao ramo industrial ou ao ramo estratégico.

As instituições formadoras do SNI possuem características próprias dependendo do país em que estão inseridas. Fatores como tamanho do país, agenda das políticas e recursos humanos, financeiros e naturais, combinados a fatores culturais e sociais geram diferentes tipos de SNIs.

Segundo Patel e Patterson (1995 apud BARBIERI; SIMANTOB, 2007, p.15), há três categorias evolutivas de SNIs:

- sistemas maduros: que têm capacidade de manter o país próximo à fronteira tecnológica internacional, como é o caso, por exemplo, dos Estados Unidos, da Alemanha e do Japão;

- sistemas intermediários: que são voltados basicamente para a difusão da inovação, com forte capacidade doméstica de absorver os avanços técnicos gerados nos sistemas maduros. É o caso, por exemplo, da Suécia, Holanda e Coréia do Sul;

- sistemas incompletos: que são os que possuem infra-estrutura tecnológica mínima. Possuem sistemas de C\&T, porém não os transformam em efetivos sistemas de inovação. É o caso, por exemplo, do Brasil, México e Argentina.

Alguns modelos que retratam as interligações entre os agentes do SNI estão presentes na literatura sobre a área. Um dos mais conhecidos é o modelo chamado de Triângulo de Sábato, representado na figura 5. Este modelo, criado por Jorge Sábato em 1968, coloca em cada vértice do triângulo o governo, as instituições de ensino e pesquisa e o sistema produtivo; cada qual exercendo influência específica no processo de inovação. $O$ modelo reflete o fato de a inovação ser um processo social, por meio das interações bilaterais entre os componentes dos vértices, gerando uma integração entre pessoas e idéias. 


\section{Fase 2}

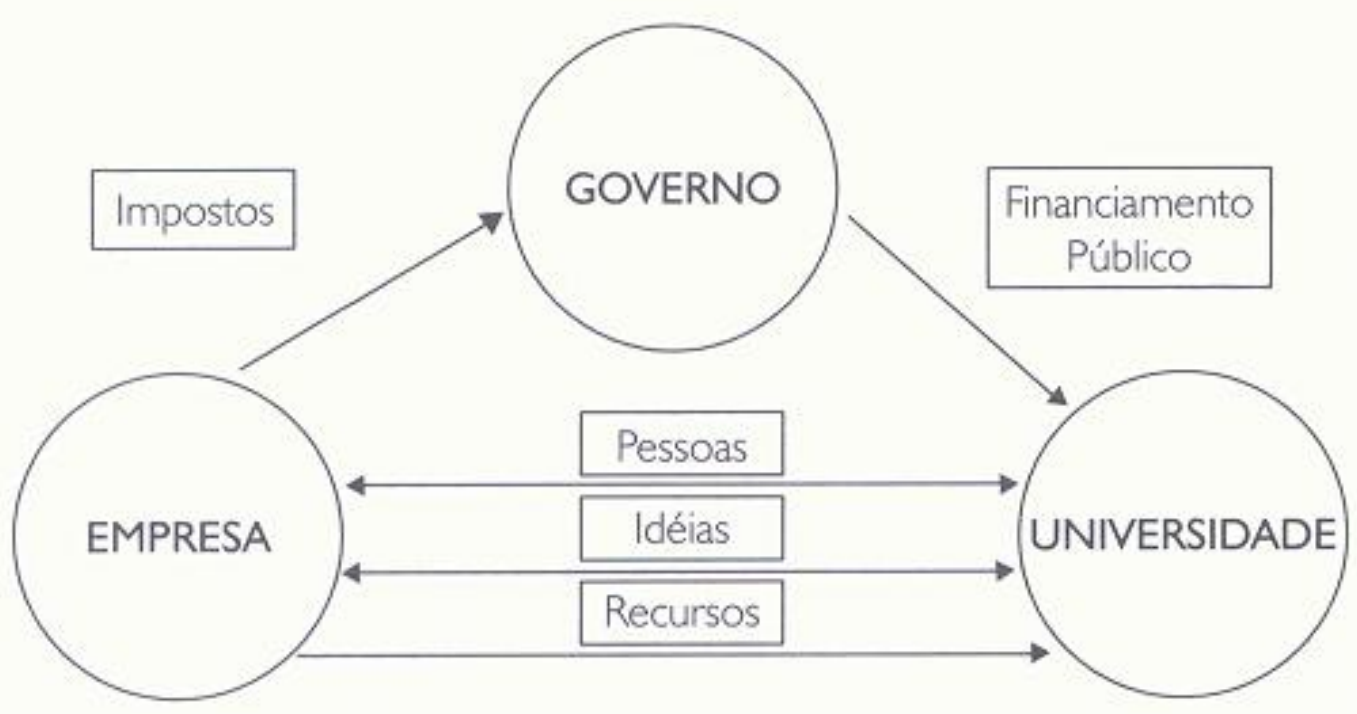

Figura 5 - Modelo de SNI: Triângulo de Sábato

Fonte: Barbieri e Simantob (2007), p.18

Outro modelo bastante conhecido é o da Hélice Tríplice, criado por Leydesdorff e Etzkowitz em 1998, representado na figura 6. Esse modelo aborda a inovação como um processo mais interativo e complexo que o modelo do Triângulo de Sábato. É um modelo espiral de inovação que representa as múltiplas relações recíprocas em diferentes estágios do processo de geração e disseminação do conhecimento. Cada hélice é uma esfera institucional independente, que atua em cooperação e interdependência com as demais esferas, através de fluxos de conhecimento entre elas. Além dessas conexões, cada esfera institucional assume o papel das outras. Assim, as universidades assumem postura empresarial, licenciando patentes e criando empresas de base tecnológica; enquanto firmas desenvolvem uma dimensão acadêmica, compartilhando conhecimentos entre elas e treinando seus funcionários em níveis cada vez mais elevados de qualificação. 


\section{Fase 3 \\ Hélice Tríplice}

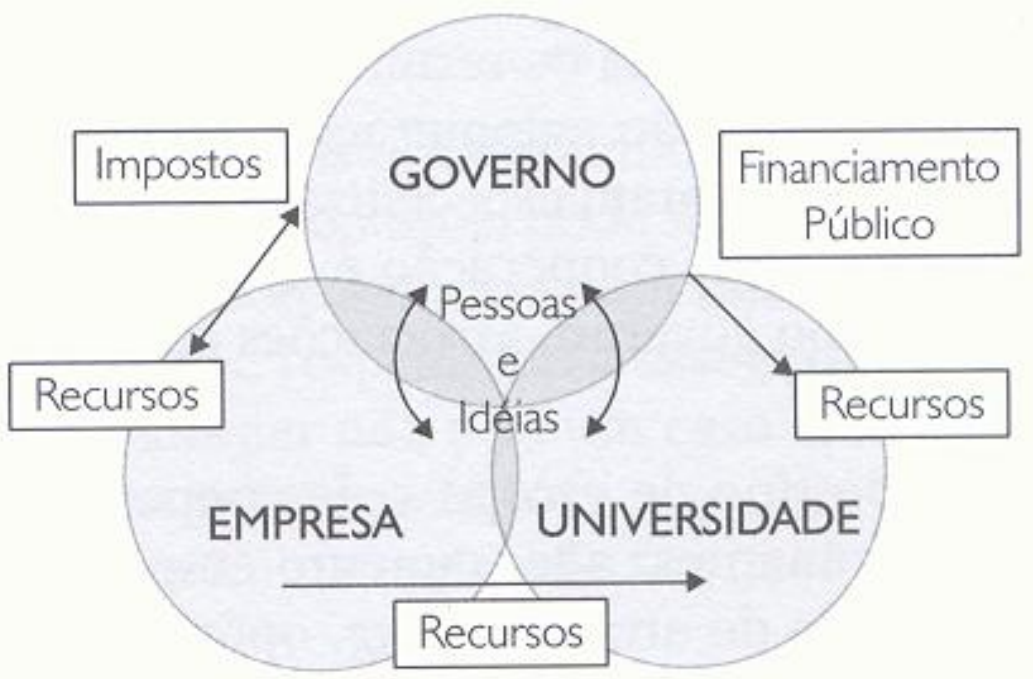

Figura 6 - Modelo de SNI: Hélice Tríplice

Fonte: Barbieri e Simantob (2007), p.19

Em uma dimensão menor de SNI, existem os Sistemas Locais de Inovação. Esses sistemas atuam de forma semelhante ao SNI, porém concentram-se em cooperação de empresas que possuem a mesma especialização produtiva e que são localizadas em um mesmo território. Estas empresas mantêm algum vínculo de articulação, interação, cooperação e aprendizagem entre si e com outros atores locais, tais como governo, associações empresariais, instituições de crédito, ensino e pesquisa. A diferença básica entre os Sistemas Locais e o Sistema Nacional é que o primeiro é voltado para o crescimento econômico geograficamente localizado, fazendo aflorar competências regionais que se transformam em produtos com alcance e competitividade internacional; já o segundo é voltado para o progresso tecnológico com geração de riqueza para o país.

Portanto, SNI pode ser descrito como a capacidade de um país de fomentar políticas de C\&T e de criar entidades com capacidade de implementá-las.

Esses sistemas são de grande importância na atual Era do Conhecimento, também conhecida como Era do Aprendizado, em que nos encontramos. A transferência do conhecimento tácito, ou seja, aquele adquirido por meio da experiência, só ocorre por meio das interações entre diferentes instituições. Esse conhecimento é o principal impulsionador do processo de inovação e conseqüente desenvolvimento do país. 


\subsection{Gestão de Pesquisa e Desenvolvimento (P\&D)}

Esta seção é dedicada ao entendimento sobre gestão de P\&D. Para isso, serão explicitados a seguir alguns modelos de inovação tecnológica, aspectos sobre gestão de portfólio de projetos de P\&D e métodos de seleção desses projetos.

\subsubsection{Modelos de Inovação Tecnológica em organizações de P\&D}

Um modelo de inovação deve considerar o processo de inovação e as condições sociais que o influenciam. Por processo de inovação, entenda como sendo suas etapas e suas características, tal como os altos riscos envolvidos no processo devido as mudanças no cenário. A gestão da inovação é fator crucial para o sucesso do modelo de inovação adotado pela organização.

Kant (1988 apud LIMA, CASTRO, ANDRADE, CARVALHO, 2004) propõe um modelo de inovação partindo das etapas envolvidas nos microprocessos de geração de uma inovação para derivar fatores sociais e estruturais que a facilitariam. Para Kant, as principais fases de geração de uma inovação são:

- Geração de idéia e ativação da inovação. Essa é a fase de identificação de uma oportunidade para o desenvolvimento de uma inovação. Essa etapa é facilitada por alguns fatores, tais como: ligações próximas com fonte de demandas, incentivo organizacional à inovação e incentivo a ligações com o meio ambiente;

- Construção de coalizões. É a fase de apresentação do projeto identificado na etapa anterior à organização. É onde há o convencimento dos participantes da organização sobre a relevância do projeto e a obtenção de elementos essenciais ao projeto, tais como conhecimento, recursos e suporte organizacional. Nessa etapa é essencial a comunicação aberta para identificar aliados ao projeto;

- Realização da idéia e produção da inovação. É a fase de desenvolvimento efetivo do projeto. É facilitada por equipes de pesquisa pequenas, continuidade do pessoal envolvido na inovação, equilíbrio entre autonomia e responsabilidade e flexibilidade para redirecionar o projeto de acordo com as mudanças ocorridas; 
- Transferência e difusão da inovação gerada. Essa fase corresponde a efetiva implementação da inovação, pois é ela que vai mostrar sobre a aplicabilidade da inovação e sua sustentabilidade no mercado. Por isso, é importante a ligação próxima entre desenvolvedores e clientes, além da receptividade institucional para com a inovação.

Outro modelo que busca explicar esse processo de geração de inovação é o de Amabile (1996 apud LIMA, CASTRO, ANDRADE, CARVALHO, 2004). Em seu modelo, o ambiente organizacional além de prover recursos tangíveis para que a inovação ocorra, ele também influencia no processo. Isso ocorre porque o ambiente organizacional propicia a motivação para inovação e influencia nas práticas de gestão da inovação e da criatividade. Portanto, gera efeitos sobre a criatividade das equipes e dos indivíduos. Esse modelo possui as seguintes etapas:

- Definição da agenda, estabelecida pela missão organizacional. Essa etapa é influenciada pela motivação das equipes e dos indivíduos a inovar.

- Definição dos cenários, onde objetivos amplos, recursos e pesquisa são definidos e realizados. Essa etapa é influenciada pelas habilidades de gestão da organização.

- Produção de idéias de produtos ou serviços. Essa etapa é influenciada pela criatividade das equipes e dos indivíduos da organização.

- Teste de implementação de idéias, envolvendo desenvolvimento, testes de mercado e ampla consideração de idéias. Essa etapa é influenciada pelos recursos disponibilizados à inovação e pelas habilidades organizacionais em gestão.

- Avaliação do resultado do processo. Essa etapa mostra se a inovação obteve sucesso, fracasso ou se necessita de mais estudos para alcançar o objetivo desejado.

A figura 7 representa o modelo de inovação tecnológica proposto por Amabile, mostrando as interligações entre as etapas citadas acima e alguns fatores que facilitam o processo, tais como a motivação para inovar e os recursos disponíveis. 


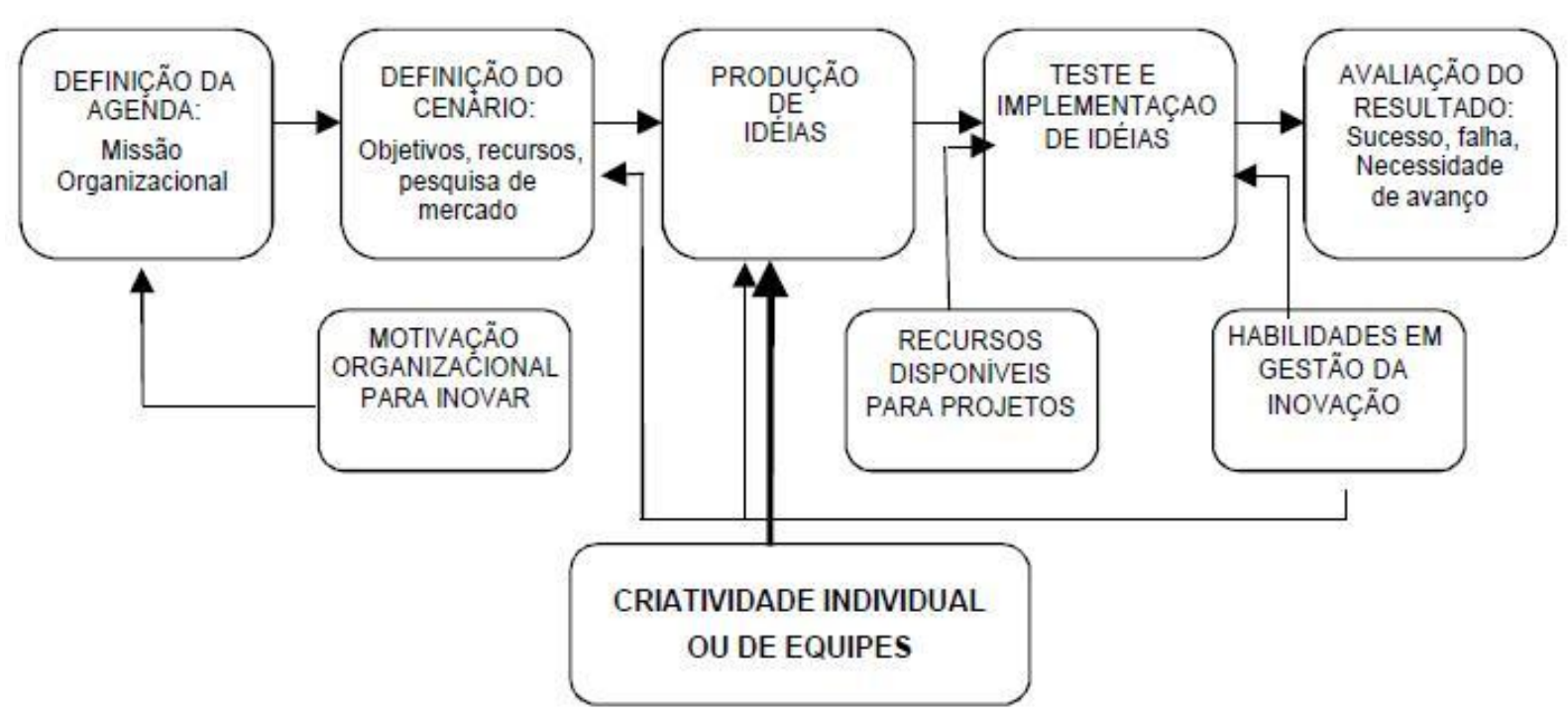

Figura 7 - Modelo de Inovação Tecnológica proposto por Amabile Fonte: Lima, Castro, Andrade e Carvalho (2004), p.90

Lima, Castro, Andrade e Carvalho (2004) propõem um modelo integrador, representado na figura 8 . Nesse modelo, características associadas às equipes de pesquisa juntamente com os recursos financeiros e materiais são considerados insumos para o processo de pesquisa e desenvolvimento. Esses insumos desencadeiam o processo de inovação, o qual é influenciado pelas práticas de gestão da organização e pelo sistema de inovação em que está inserido. As etapas do processo são as seguintes:

- Identificação de uma necessidade ou demanda tecnológica. Nessa etapa os pesquisadores interessados no problema identificado buscam uma solução para tal.

- Após a etapa anterior, os pesquisadores irão apresentar argumentos a favor daquela proposta de solução, buscando potenciais parceiros para a adequação da proposta a demanda dos clientes. Ocorre também nessa segunda etapa a divisão das responsabilidades entre equipes, a negociação de divisão dos resultados da pesquisa (patentes, publicações) e dos recursos, e a escolha de lideranças para o projeto.

- A terceira etapa consiste na produção do protótipo. É nessa etapa que são tomadas todas as ações para transformar as idéias em um produto pronto para ser submetido a testes e a validação. Dependendo das incertezas do projeto, o planejamento deste deve ser reformulado para evitar prejuízos. 
- Na quarta etapa, ocorre o teste, validação e finalização do protótipo desenvolvido na etapa anterior. Nessa etapa, o conhecimento de clientes e suas demandas, a seleção dos testes apropriados e a seleção dos clientes para participar dos testes são essenciais.

- A última etapa corresponde a transferência da inovação desenvolvida. Essa etapa pode variar de acordo com as características do produto desenvolvido, com as características do mercado onde o produto será consumido e com a capacidade de articulação local com organizações que devem entregar 0 produto final ao consumidor.

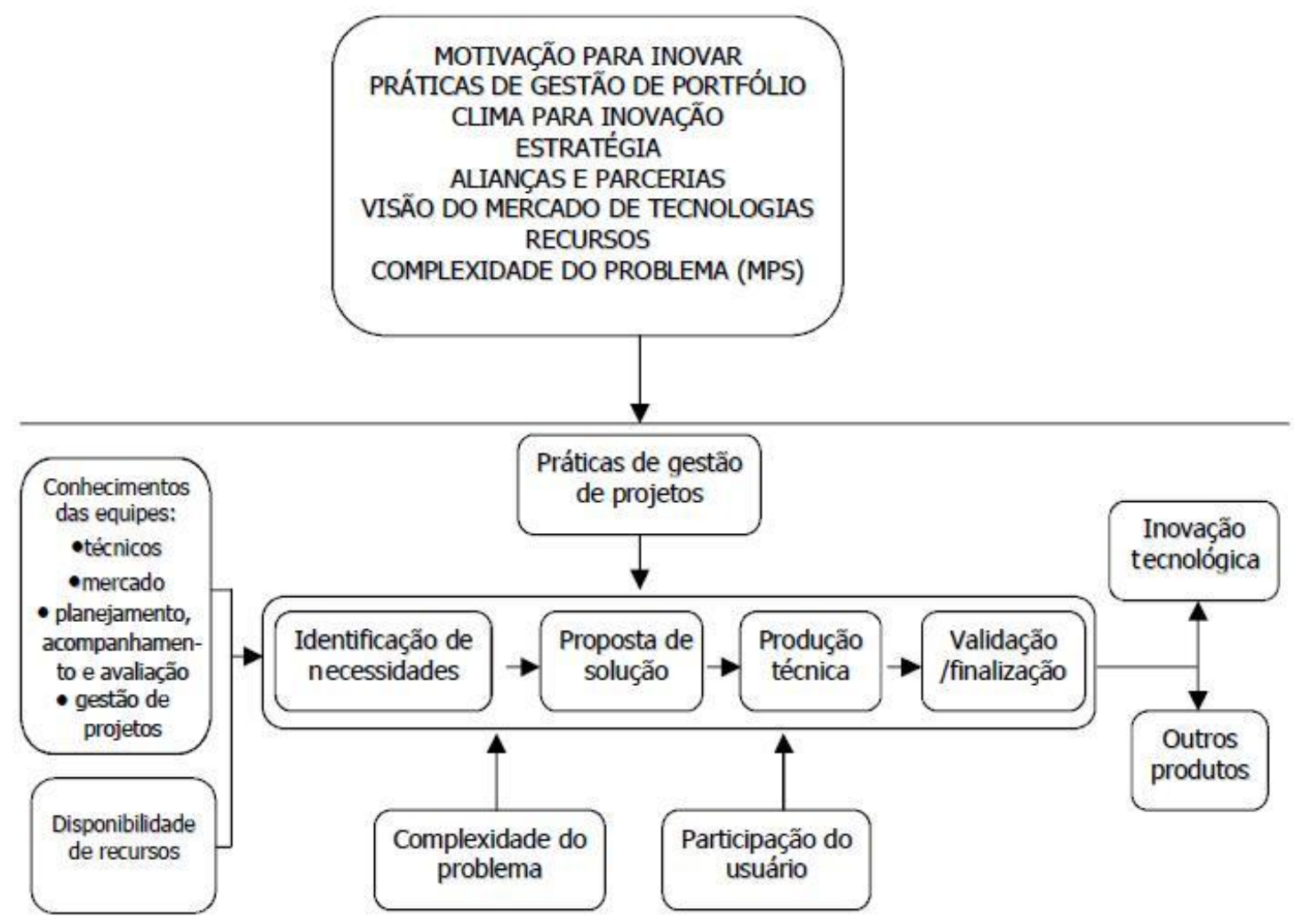

Figura 8 - Modelo Integrador de Inovação Tecnológica Fonte: Lima, Castro, Andrade e Carvalho (2004), p.95

Nesse modelo, são considerados produtos da inovação tanto o produto efetivamente gerado, como também outras tecnologias e conhecimentos gerados ao longo do processo de inovação. O conhecimento sobre gestão adquirido pelas equipes e pelos gestores é importante produto do processo. A aprendizagem gerada possibilita a transformação do conhecimento tácito em codificado. 
Essa capacidade de aprendizagem da organização constitui importante fonte de sustentabilidade institucional em organização de pesquisa, pois possibilita a transformação do conhecimento tácito em codificado. A incorporação sistemática desse conhecimento pelos membros da empresa proporciona vantagem competitiva a esta. Isso ocorre porque há uma retroalimentação positiva do processo de P\&D, posto que há o aumento da base de conhecimento das equipes de pesquisa e o fortalecimento das estratégias criativas.

\subsubsection{Gestão de Portfólio de Projetos de P\&D}

A gestão da tecnologia e da inovação é feita por projetos. Com base nessa premissa, Mattos e Guimarães (2005, p.24) definem projeto como um conjunto de ações executadas de forma coordenada por uma estrutura organizacional para alcançar um objetivo determinado, com determinados recursos e em um determinado tempo.

Em uma organização voltada para $P \& D$, há vários temas interessantes a serem pesquisados. Assim, não existe apenas um projeto sendo desenvolvido em um mesmo período de tempo. Para que não faltem recursos a nenhum dos projetos, é necessária uma gestão de projetos eficaz.

A gestão de portfólio de projetos é definido por Archer e Ghasemzadeh (1999 apud RABECHINI, MAXIMIANO, MARTINS, 2005) como uma coleção de projetos que são desenvolvidos sob a administração de uma unidade organizacional. Cada projeto deve fazer parte dos objetivos estratégicos da organização e possuir recursos para o seu desenvolvimento.

Crawford (2002 apud RABECHINI, MAXIMIANO, MARTINS, 2005) propõe um modelo de gerenciamento de portfólio que deve ser guiado pelos seguintes passos. O primeiro passo se refere à identificação dos projetos. Nessa etapa aspectos estratégicos e táticos dos projetos devem ser considerados. Em seguida critérios para a avaliação dos projetos são escolhidos, visando à hierarquização de prioridades. Esses critérios devem estar relacionados com o alinhamento do projeto às estratégias da organização. Após a avaliação dos projetos segundo os critérios pré-estabelecidos, segue-se para a formação da carteira de projetos a serem desenvolvidos. O acompanhamento do desenvolvimento dos projetos é a última fase. Nela são avaliados aspectos como a determinação de prazos e recursos, e o 
andamento do projeto. Caso o desenvolvimento deste não ocorra da maneira como planejada, é hora de interromper seu andamento.

O modelo proposto por Rabechini, Maximiano e Martins (2005) é mais complexo que o apresentado acima. Ele é composto de seis etapas, iniciando-se pela preparação para a implementação da gestão de portfólio. Nessa etapa é importante o entendimento sobre as estratégias da empresa e de seu modelo de negócio para uma boa metodologia para a análise dos projetos. A identificação de critérios e a atribuição de pesos para cada um desses ajuda na seleção dos projetos. Após esta fase, tem-se a formação da lista de projetos que poderão formar a carteira de projetos a serem desenvolvidos. Assim, aspectos como objetivos do projeto, prazos, custos, recursos necessários, indicadores, restrições envolvidas e riscos devem ser conhecidos. A terceira etapa diz respeito à avaliação dessa lista de projetos, visando à priorização desses. Essa avaliação deve ser feita por pessoas credenciadas pela organização e por um comitê que avaliará aspectos táticos (efetividade do projeto) e estratégicos (alinhamento com as estratégicas da organização).

A formação da carteira de projetos e o plano de gerenciamento de portfólio ocorrem na quarta etapa. Os projetos que passaram pelos filtros anteriores dão origem a carteira de projetos a serem desenvolvidos. Na quinta etapa ocorre a administração do portfólio de projetos. Aspectos como controle dos recursos, acompanhamento do ciclo de vida do projeto, custos e competência dos recursos humanos devem ser gerenciados. A última etapa é referente à revisão e controle do projeto. Essa etapa deve ocorrer por meio de reuniões periódicas com as equipes de cada projeto para avaliar seu andamento. Com base nisso, pode haver a modificação do portfólio de projetos da empresa.

Os modelos presentes na literatura servem como base para as empresas, porém na maioria das vezes eles são adequados a realidade de cada uma. Isso faz com que etapas podem ser adicionadas ao processo, assim como podem ser retiradas. 


\subsubsection{Seleção de Projetos de P\&D}

A seleção de projeto é uma etapa crucial no processo de inovação. Assim, para que as decisões sejam tomadas da forma mais concreta e acertada possível, é necessário que a organização possua um método estruturado para a escolha dos projetos a serem desenvolvidos.

A seleção de projetos de P\&D é dificultada pela falta de dados sobre o assunto. Riscos, cenários de incerteza, alto comprometimento de recursos materiais e humanos por longos períodos de tempo são alguns aspectos que dificultam esse processo. Na literatura há várias metodologias que podem ser utilizadas para facilitar a seleção dos projetos. Há métodos de todos os tipos, desde totalmente quantitativos a totalmente qualitativos, cabendo a empresa utilizar o método mais adequado a sua realidade e a seus objetivos.

Gibson (1981 apud MORAIS F., WEINBERG, 2002) classifica os métodos de seleção de projetos em cinco categorias.

- Ordenamento: consiste na classificação dos projetos mediante comparação entre as diversas possibilidades, considerando um conjunto padrão de preferências. Essa técnica é muito centrada na intuição e não há como comprovar os meios que foram utilizados para a seleção dos projetos.

- Pontuação (scoring): consiste na pontuação dos critérios de escolha e na atribuição de pesos aos critérios. Ao final é calculada a soma dos valores, e com base nisso ocorre a seleção dos projetos. A grande vantagem desse método é explicitar os critérios de escolha.

- Pontuação por índices econômicos: consiste na utilização de taxas calculadas com base no fluxo de caixa do projeto. Algumas taxas são: taxa interna de retorno, valor presente e tempo de retorno do investimento. Essa técnica não é de grande valia para os projetos de P\&D, devido a falta de dados que permitam construir um fluxo de caixa com baixa margem de erro.

- Métodos formais de otimização: consiste no emprego de rotinas de programação linear e não-linear para selecionar a alternativa que 
maximiza a função lucro. Seu emprego é dificultado para projetos de P\&D, devido a falta de dados concretos.

- Análise de risco: consiste na aplicação de índice de probabilidade, tais como técnico, comercial e econômico, sobre o quociente benefício/lucro. O estabelecimento de índices envolve muita subjetividade.

A maioria das técnicas utilizadas na seleção dos projetos de P\&D encontra-se dentro da classificação de pontuação. A metodologia proposta por Ansoff (1964 apud MORAIS F., WEINBERG, 2002) consiste no cálculo de índices de lucro e de risco a partir de 11 parâmetros, dentre os quais estão aspectos que envolvem tecnologia, negócio, receita ao longo do tempo, probabilidade de sucesso técnico e mercadológico e custos. Essa metodologia é criticada por Dumbleton (1986 apud MORAIS F., WEINBERG, 2002), pois não há razão a priori para a utilização desses parâmetros.

Outro método é o índice de Merrifield (1978 apud MORAIS F., WEINBERG, 2002). Esse método consiste na multiplicação da probabilidade de sucesso comercial pela probabilidade de sucesso técnico. A probabilidade de sucesso comercial é calculada baseada na soma de 12 fatores, sendo que seis são relativos à atratividade do negócio e seis são relativos aos pontos fortes da organização. Dentre os fatores estão: potencial de vendas, distribuição do risco, capacitação de produção, base tecnológica e competência gerencial. Quanto à probabilidade de sucesso técnico, Morais F. e Weinberg afirmam que Merrifield não detalha os aspectos a serem considerados.

Martino (1994 apud MORAIS F., WEINBERG, 2002) propõe um método baseado em quatro variáveis: custo do projeto $(C)$, tamanho do mercado $(M)$, market-share potencial (S) e probabilidade de sucesso técnico $(\mathrm{T})$. A pontuação é feita de acordo com a seguinte fórmula: Pontuação $=T^{*}(M+2 S) / C$. Porém Morais $F$. e Weinberg (2002) criticam esse método pelo fato da probabilidade do sucesso técnico não ser decomposta em índices, o que faz com o processo seja subjetivo, e também pelo método não considerar o alinhamento dos projetos às estratégias da empresa.

O método proposto por Morais F. e Weinberg (2002) visa documentar o processo de seleção de projetos, permitir a reavaliação futura das decisões e considerar explicitamente os aspectos subjetivos. Assim, ele é um método estatístico, mas que emprega pesquisa de opinião de especialistas. $O$ método 
consiste nas seguintes etapas. A primeira consiste na definição dos fatores de priorização e seleção de projetos. Em seguida, notas são atribuídas a cada projeto com base nos critérios pré-definidos. Esse processo envolve o maior número de pessoas possível, dentre os quais estão no mínimo a diretoria, a área comercial e a área de P\&D da organização. Finalmente, é dado um tratamento estatístico para as notas e para cada projeto é dado um grau de prioridade, dentro de um número limitado de categorias. Esse método visa agrupar os projetos por ordem de prioridade (alta, média e baixa) para em seguida escolher efetivamente os projetos a serem desenvolvidos.

A classificação dos projetos por ordem de prioridade é feita com base em dois aspectos: exeqüibilidade, ou seja, facilidade do projeto ser colocado em prática; e o interesse dos avaliadores em executá-los. A avaliação da relação entre exeqüibilidade e interesse determina a prioridade do projeto.

Como essa avaliação é bastante subjetiva, é necessário que os aspectos de exeqüibilidade e interesse possuam critérios que possam ser quantificados para facilitar a classificação. Assim, são utilizados três critérios para o aspecto exeqüibilidade: grau de segurança tecnológica (se o projeto de P\&D é viável), prazo para a obtenção de resultados e investimento necessário para o projeto. Os critérios utilizados para o aspecto interesse são: aderência a estratégia da empresa, nível de receita a ser gerada pelo projeto e efeito do projeto em mercados ainda não atendidos.

Após todos esses aspectos serem definidos, a próxima etapa é a realização da pesquisa de opinião com especialistas. Eles atribuirão para cada projeto, notas para os seis critérios estabelecidos. A média aritmética das notas do critério dada pelos especialistas forma a nota final do critério para um determinado projeto. Seguindo o mesmo raciocínio, a nota final do aspecto exeqüibilidade do projeto é dada pela média das notas finais dos três critérios que fazem parte deste. O mesmo ocorre para o aspecto interesse. Ao final dessa etapa, cada projeto possui um par de notas, as quais são colocadas em um gráfico, no qual se define as prioridades.

A figura 9 representa o gráfico, com os graus de prioridades e os códigos dos projetos analisados. 


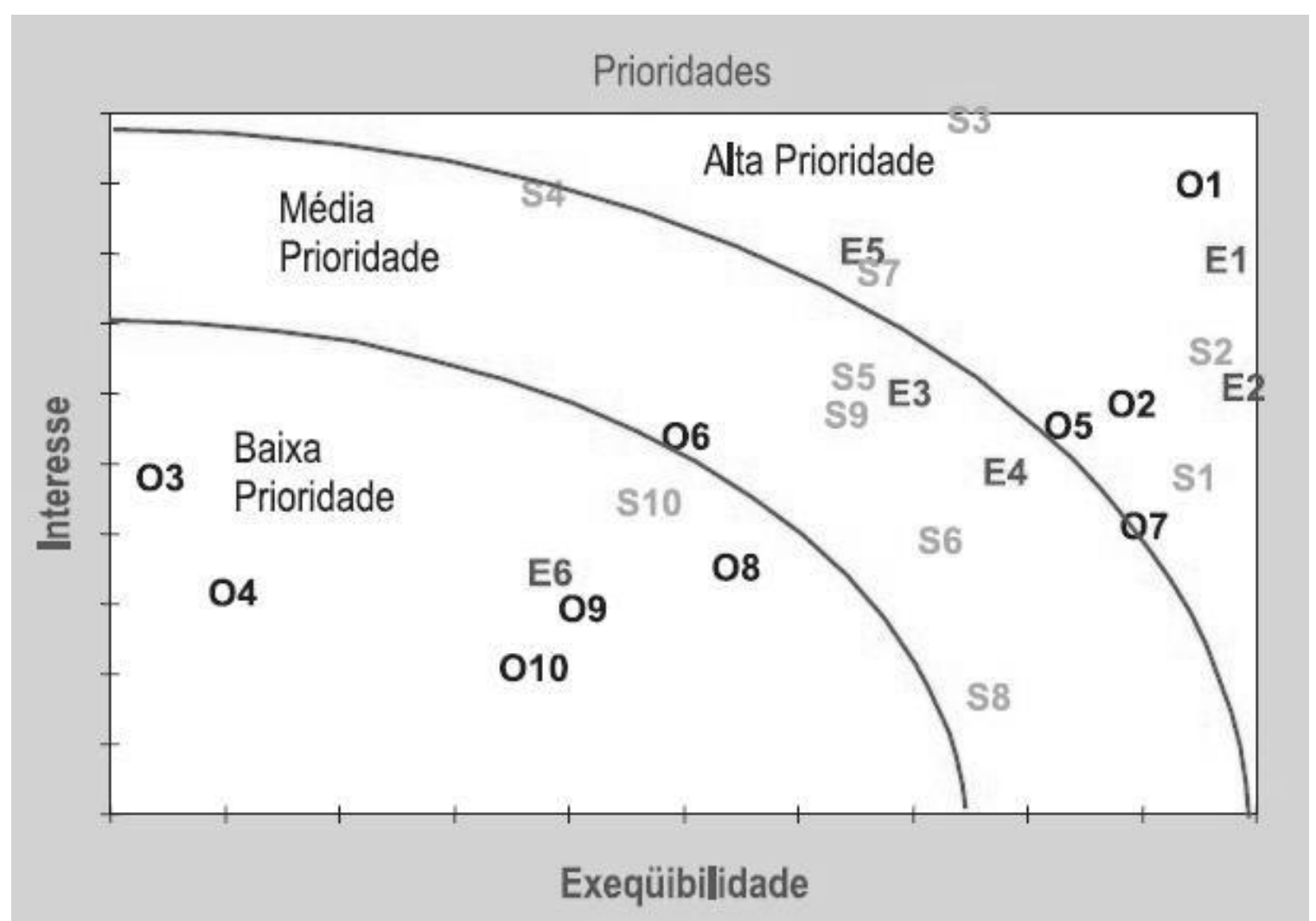

Figura 9 - Gráfico Interesse x Exequibilidade, com os códigos dos projetos Fonte: Morais F. e Weinberg (2002), p.90

Esse modelo proposto por Morais F. e Weinberg (2002) é mais voltado para a seleção de projetos de P\&D industrial, ou seja, voltado para o desenvolvimento de produtos. Assim, os critérios adotados são mais voltados para essa área. Se o modelo for utilizado por universidades ou empresas de pesquisa, outros critérios devem ser considerados. 


\section{MÉTODOS E TÉCNICAS DE PESQUISA}

O objetivo deste trabalho é entender como é feito o processo de seleção de projetos de pesquisa e desenvolvimento (P\&D) na Empresa Brasileira de Pesquisa Agropecuária (Embrapa). Para isso, a estratégia de pesquisa utilizada foi a de estudo de caso, já que é necessário entendimento profundo sobre o processo em questão. A seguir serão apresentados maiores detalhes sobre essa estratégia de pesquisa, a justificativa de sua escolha e a análise dos dados coletados.

\subsection{A Estratégia de Pesquisa Baseada em Estudo de Caso}

A pesquisa foi feita baseada na estratégia de estudo de caso. O estudo de caso deve ser utilizado quando questões do tipo "como" e "por que" são objeto da pesquisa (YIN, 2005, p.19). Além disso, o estudo de caso é utilizado para contribuir para o conhecimento dos fenômenos individuais, organizacionais, sociais, políticos e de grupo. Tendo esses aspectos em vista, o estudo de caso único se faz como uma estratégia adequada à presente pesquisa, pois esta propõe analisar como ocorre o processo de seleção de projetos de $P \& D$ dentro de uma determinada organização, no caso a Empresa Brasileira de Pesquisa Agropecuária (Embrapa).

Existem algumas definições desse método de pesquisa. Yin (2005) define estudo de caso como "a investigação empírica que investiga um fenômeno contemporâneo dentro de seu contexto na vida real, especialmente quando os limites entre fenômeno e o contexto não estão claramente definidos".

Roesch (2005, p.201) identifica três características que definem o estudo de caso como estratégia de pesquisa. A primeira é que ele permite o estudo de fenômenos em profundidade dentro de seu contexto. A segunda é que ele é especialmente adequado ao estudo de processos, pois permite uma análise contextual e longitudinal das várias ações e significados que se manifestam e se constroem dentro da organização (Hartley, 1994 apud ROESCH, 2005). E a última característica diz respeito a exploração de fenômenos com base em vários ângulos. Yin (2005, p.34) coloca que os estudos de caso podem se basear em qualquer mescla de provas quantitativas e qualitativas, afastando a idéia de que ele é uma pesquisa qualitativa. 
Assim, a essência do estudo de caso é que ele tenta esclarecer uma decisão, ou um conjunto de decisões, explicando o motivo pelo qual foram tomadas, como foram implementadas e quais foram os resultados alcançados (Schramm, 1971 apud YIN, 2005, p.31).

O estudo de caso, segundo Roesch (2005), tem sido utilizado na Administração com diversos propósitos: utilização de casos para ensino, casos que se destinam a relatar práticas de organizações ou oferecer alternativas políticas, e os casos que buscam contribuir para o avanço do conhecimento. Assim, eles podem ser tanto práticos como teóricos.

Os estudos de caso podem ser classificados também em específicos ou genéricos. Stake (1994 apud ROESCH, 2005, p.203) diferencia os estudos de caso intrínsecos, dos instrumentais e coletivos. Ele defende o uso dos estudos de caso intrínsecos, que são aqueles destinados a entender melhor um caso particular; pois coloca que a insistência em criar teoria ou generalizar tende a desviar a atenção do pesquisador de aspectos importantes do caso. Porém, autores como Walton (1995 apud ROESCH, 2005, p.204) salientam a importância dos aspectos instrumentais do estudo de caso para o desenvolvimento de teorias em ciências sociais. Ele argumenta que na lógica da pesquisa, busca-se encontrar casos férteis, medir seus aspectos fundamentais, demonstrar conexões causais entre seus elementos e sugerir algo sobre a generalidade de seus resultados. Assim, o que interessa é o potencial do caso para a construção de teorias.

Já autores como Yin (1994), privilegiam os estudos de caso coletivos, ou seja, aqueles voltados para a investigação de múltiplos casos. Ele defende que os estudos de caso podem ser usados com propósitos exploratórios, descritivos ou explicativos. E salienta que para a análise de múltiplos casos deve-se utilizar a lógica de replicação e não a de amostragem. A lógica de replicação consiste em afirmar que casos individuais podem ser usados para uma confirmação independente de proposições específicas.

A última classificação dos estudos de caso é em relação a sua contribuição à teoria. Eckstein (1975 apud ROESCH, 2005, p.205) propõe cinco maneiras de contribuição. Os estudos ideográficos-configurativos são aqueles que são altamente descritivos, específicos à situação e que não levam a interpretações teóricas gerais. Já nos estudos configurativos-disciplinados, o pesquisador procura interpretar os padrões que encontra em termos de postulados teóricos gerais. No caso dos 
estudos heurísticos, a situação é deliberadamente escolhida para gerar teoria. Buscam discernir problemas gerais e soluções teóricas possíveis. Os estudos de sondagens de plausalidade são aqueles escolhidos para testar a teoria atual. $E$ os estudos de caso cruciais são aqueles voltados para rejeitar ou apoiar proposições teóricas.

Esse estudo pode ser caracterizado como específico, descritivo e ideográficoconfigurativo, já que ele analisa um caso único e descreve o processo de seleção de projetos de P\&D dessa empresa, buscando apenas encaixá-lo na teoria e não generalizar o caso para criar uma teoria.

\subsection{Objeto de Estudo}

A pesquisa ocorreu na Empresa Brasileira de Pesquisa Agropecuária (Embrapa). A Embrapa é uma empresa pública dotada de personalidade jurídica de direito privado, com patrimônio próprio, autonomia administrativa e financeira, vinculada ao Ministério da Agricultura, Pecuária e Abastecimento. Foi constituída pela Lei n. 5.851, de 7 de dezembro de 1972, e criada em 26 de abril de 1973.

Sua criação marcou a mudança do modelo de gestão de pesquisa agropecuária do país. Antes, o modelo era difuso, ou seja, havia grande variedade de temas de pesquisa com enfoques distintos e liberdade de escolha do pesquisador sobre o tipo de pesquisa que iriam desenvolver. Com a criação da Embrapa, o modelo de gestão adotado passou a ser o concentrado. Esse modelo possuía três pilares: a concentração dos esforços de pesquisa em torno de uma agenda nacional regida por áreas consideradas estratégicas pelo Governo Federal para atender às necessidades do país, a formação em larga escala de especialistas e o forte investimento na construção de laboratórios e financiamento de pesquisa alinhada aos temas da agenda nacional.

Os projetos de P\&D desenvolvidos pela Embrapa são os principais responsáveis pelo estágio produtivo agropecuário em que o Brasil se encontra. Atualmente, ela é reconhecida internacionalmente por suas pesquisas e pelo desenvolvimento proporcionado ao país. Possui 8.275 empregados, dos quais 2.113 são pesquisadores. Dentre seus pesquisadores, 529 possuem mestrado (25\%) e 1564 possuem doutorado (74\%). Além disso, possui unidades no exterior, em países 
como Estados Unidos, Holanda, França, Gana e Venezuela; por meio do projeto Laboratório Virtual da Embrapa no Exterior (Labex). No Brasil, atua por intermédio de Unidades de Pesquisa e Serviço e Unidades Administrativas espalhadas por quase todas as federações do país.

\subsection{Procedimentos e instrumentos utilizados na coleta e análise dos dados}

Yin (2005) coloca que existem seis fontes para se coletar evidências para um estudo de caso: documentos, registros de arquivo, entrevistas, observação direta, observação participante e artefatos físicos. Além disso, é importante que na coleta de dados para estudos de caso se utilize várias fontes de evidências, que haja a formação de um banco de dados e o encadeamento de evidências, ou seja, ligação explícita entre as questões feitas, os dados coletados e as conclusões.

Cada uma das fontes de evidências possui suas vantagens e desvantagens, por isso é necessário que haja a utilização de mais de um instrumento para se ter maior embasamento sobre o que ocorre dentro da organização.

Nesta pesquisa, a coleta de evidências ocorreu por meio de entrevista aberta e análise documental. A entrevista é indicada quando se quer um conhecimento mais aprofundado do processo, e por isso se faz importante para o presente trabalho, posto que este tem como objetivo analisar o processo de seleção de projetos de P\&D de uma única organização, a Embrapa. Portanto, o instrumento de coleta se faz adequado já que é necessário conhecimento aprofundado sobre o assunto para que a análise crítica seja consistente.

Para alcançar os objetivos, a coleta de dados ocorreu por meio de análise documental, entrevista aberta e pela revisão da literatura sobre o assunto, como indicada no quadro 2.

A entrevista foi feita com o chefe substituto do Departamento de Pesquisa e Desenvolvimento da Embrapa Sede, localizada em Brasília, apenas para confirmação dos dados coletados por meio de documentos. Os documentos que serviram de base para a análise foram encontrados no site da empresa (www.embrapa.br) e alguns foram fornecidos pelo entrevistado. 


\begin{tabular}{|c|c|}
\hline Objetivos do estudo & Técnicas de coleta de dados utilizadas \\
\hline $\begin{array}{l}\text { Identificar os modelos de P\&D presentes } \\
\text { na literatura. }\end{array}$ & Revisão da literatura \\
\hline $\begin{array}{l}\text { Caracterizar o modelo de P\&D da } \\
\text { Embrapa: histórico da empresa, } \\
\text { evolução do modelo de P\&D da empresa } \\
\text { e descrição do Sistema Embrapa de } \\
\text { Gestão (SEG). }\end{array}$ & $\begin{array}{c}\text { Entrevista, análise documental e revisão } \\
\text { da literatura sobre o tema }\end{array}$ \\
\hline $\begin{array}{l}\text { Analisar o processo de seleção de } \\
\text { projetos de P\&D da Embrapa: descrição } \\
\text { do processo }\end{array}$ & Entrevista e análise documental \\
\hline
\end{tabular}

Quadro 2 - Objetivos X Coleta dos dados

A análise dos dados consiste em examinar, categorizar e recombinar as evidências quantitativas e qualitativas para tratar as proposições iniciais de um estudo. Nessa etapa da pesquisa, a apresentação suficiente de evidências e a análise cuidadosa das interpretações são muito importantes.

Para as pesquisas baseadas em estudos de caso, Yin (2005) propõe três estratégias analíticas gerais para guiar a análise dos dados. A primeira consiste em seguir as proposições teóricas que levaram ao estudo de caso. A segunda estratégia tenta definir e testar explanações concorrentes, tais como hipóteses nulas, ameaças à validade e viés do pesquisador. A última estratégia busca desenvolver uma estrutura descritiva a fim de organizar o estudo de caso. Yin coloca que a primeira e a segunda estratégias são preferíveis a terceira, porém a abordagem descritiva pode ajudar a identificar as ligações causais apropriadas a serem analisadas.

Yin (2005) propõe além das estratégias analíticas, algumas técnicas específicas para a análise dos dados. Dentre elas estão: adequação ao padrão, construção da explanação, análise de séries temporais, modelos lógicos e síntese de casos cruzados.

Nessa pesquisa a estratégia utilizada foi a baseada em proposições teóricas, e a técnica utilizada foi a de adequação do padrão. Essa técnica propõe a comparação entre um padrão fundamentalmente empírico e um outro de base prognóstica (Trochim, 1989 apud YIN, 2005, p.145). 


\subsection{Codificação e categorização}

Flick (2004) coloca que a interpretação de dados é a cerne da pesquisa qualitativa, porém cada abordagem trata da sua importância de uma maneira diferente. Para Strauss (1987 apud FLICK 2004) a interpretação de textos tem a função de desenvolver teoria, como também de orientar na decisão sobre quais dados adicionais precisam ser coletados. Assim, a coleta de dados deve ser feita de forma conjunta, ou seja, sem seguir um processo linear em que primeiramente teríamos a coleta de dados para posterior análise destes.

Flick (2004) coloca que existem duas metas opostas quando se busca interpretar um texto. A primeira é a revelação, exposição e contextualização de enunciados do texto visando enunciar uma teoria, já que esse propósito leva ao aumento da quantidade de material textual sobre o assunto. A outra é a redução do texto por meio de resumo, paráfrase ou categorização; visando a reconstrução da estrutura do texto através da análise seqüencial do texto.

Este trabalho tem como base a segunda meta, a de categorização. Nele, o material coletado por meio das entrevistas, análise documental e da revisão de literatura foi comparado com as categorias estipuladas baseadas no referencial teórico apresentado no capítulo 2.

\subsubsection{Categorias}

As categorias foram estipuladas com base no referencial teórico deste trabalho e foram tidas como medida de comparação entre o material coletado e o exposto pela teoria sobre o assunto, viabilizando assim, a análise dos dados. As categorias são as seguintes:

- Tipo de Inovação

Identificar em qual tipo de inovação (produto, processo, posição ou paradigma), o modelo de gestão de pesquisa e desenvolvimento (P\&D) adotado pela Empresa Brasileira de Pesquisa Agropecuária (Embrapa), que tem como marco o Sistema Embrapa de Gestão (SEG), se encaixa. 
- Grau da inovação

Identificar se Sistema Embrapa de Gestão (SEG) representa uma inovação radical ou incremental para a organização.

- Ciência e Tecnologia

Identificar em qual dos três objetivos, citados por Ferreira (1977), do conjunto de instituições formadores do SNI para uma política efetiva de desenvolvimento nacional, o Brasil se encontra atualmente.

- Sistema Nacional de Inovação

Identificar o papel da Embrapa, juntamente com as diretrizes do Governo Federal, na evolução do SNI do país.

- Gestão de Pesquisa e Desenvolvimento (P\&D)

- Modelo de gestão: comparar o modelo de gestão da Embrapa com os citados na teoria, visando entender qual foi a base do modelo implementado na organização

- Processo de inovação: identificar se o Sistema Embrapa de Gestão (SEG) possui todas as fases do modelo de inovação tecnológica que ele possui como base

- Gestão de portfólio de projetos: comparar as etapas de gestão de portfólio de projetos citados na literatura com as etapas contempladas pela gestão de projetos da Embrapa

- Método de seleção de projetos: identificar em qual método o processo de seleção de projetos de P\&D da Embrapa se encaixa

- Avaliação do método de seleção de projetos: identificar as vantagens e desvantagens do método de seleção de projetos de P\&D utilizado na Embrapa

- Avaliação de resultados: avaliar se os resultados dessa gestão estão contribuindo para o desenvolvimento econômico e social do país 


\section{APRESENTAÇÃO E ANÁLISE DOS RESULTADOS DA PESQUISA}

Nessa seção serão apresentados os dados coletados por meio de entrevista aberta, análise documental e revisão de literatura sobre os aspectos relevantes para o alcance dos objetivos propostos pela pesquisa, sendo o principal deles, analisar o método de seleção de projetos de P\&D a serem desenvolvidos pela Embrapa.

Primeiramente haverá um histórico da empresa, em seguida será descrito o funcionamento do modelo de P\&D da Embrapa, sistematizado no Sistema Embrapa de Gestão (SEG) e posteriormente será descrito, especificamente, o processo de seleção de projetos de $P \& D$, que é a etapa principal da gestão de projetos de $P \& D$ contemplada pelo SEG. Na última parte do capítulo, será demonstrado resultados desse modelo de gestão implementado na Embrapa.

Após a apresentação dos dados, teremos a análise desses de acordo com as categorias estipuladas pela autora no capítulo de metodologia.

\subsection{Histórico da Empresa}

A Empresa Brasileira de Pesquisa Agropecuária (Embrapa) é uma empresa pública dotada de personalidade jurídica de direito privado, com patrimônio próprio, autonomia administrativa e financeira, vinculada ao Ministério da Agricultura, Pecuária e Abastecimento. Foi constituída pela Lei n. 5.851, de 7 de dezembro de 1972, a qual moldou sua primeira forma organizacional.

A criação da Embrapa marcou a mudança de modelo de gestão da pesquisa agropecuária do país. Antes o modelo adotado era o difuso, que tinha como principais características a grande variedade de temas de pesquisa com enfoques distintos e a liberdade de escolha do pesquisador sobre o tipo de pesquisa que iria desenvolver. Esse modelo era adotado nos países desenvolvidos, porém não obteve grandes resultados aqui no Brasil devido a uma série de fatores que não eram contemplados e que para o sucesso do modelo deveriam existir, tais como a abundância de recursos destinados a pesquisa e a existência de uma massa crítica de agricultores capazes de interagir com os pesquisadores para aplicar de forma diversificada o conhecimento gerado pela pesquisa.

Devido a esse cenário, a constituição da Embrapa foi baseada em um novo modelo, o chamado modelo concentrado de pesquisa. Este tem três pilares fundamentais: a concentração dos esforços de pesquisa em torno de uma agenda 
nacional, que deve ser regida por áreas consideradas estratégicas pelo Governo Federal para atender as necessidades do país; a formação em larga escala de especialistas e o forte investimento na construção de laboratórios e financiamento de pesquisa alinhada aos temas da agenda nacional.

Até 1978, a Embrapa conduzia suas pesquisas científicas baseada no modelo linear (science push). Isso quer dizer que, apesar de as pesquisas da Embrapa terem de contemplar os grandes temas propostos pelo Governo Federal, a condição da pesquisa; ou seja, o que pesquisar, quais metas deveriam ser atingidas, eram definidas pelo pesquisador.

A partir de 1979, a Embrapa começou a implementar a estratégia do modelo linear reverso, mais voltado para a demanda (market pull). Esse modelo teve início em 1980 e foi chamado de Modelo Circular de Pesquisa. O modelo recebeu esse nome, pois propunha que a pesquisa nascia e terminava no produtor, ou seja, as pesquisas deveriam contemplar desde o desenvolvimento de variedades agrícolas e pecuárias até os insumos e técnicas necessárias para a produção, tudo de forma integrada, visando o aumento da produtividade (ALVES, 1985 apud BARBIERI; SIMANTOB, 2007, p.60). Essa mudança de foco para o produtor passa a medir o sucesso da pesquisa pelo aumento da produtividade do produtor. Assim, a pesquisa não termina com a invenção de uma nova tecnologia, mas sim com a sua adoção efetiva pelo produtor.

Outro ponto importante ocorrido na década de 80 foi o início da utilização do planejamento estratégico para guiar as ações da Embrapa. A implantação do I Plano Diretor Embrapa (PDE) em 1988 foi baseado na sistemática do planejamento estratégico com a análise de cenários futuros e a definição da missão, visão, valores e objetivos para os próximos anos. Esse planejamento foi de grande importância para a mudança na forma de conduzir as atividades de pesquisa e desenvolvimento (P\&D) na Embrapa. A missão estabelecida pelo I PDE para guiar a empresa pelos próximos anos foi:

Gerar e estimular a produção científica e tecnológica que possibilite o desenvolvimento do agronegócio e da agroindústria nacionais, visando ao bem-estar social e econômico da coletividade brasileira, através do uso racional dos recursos naturais e preservação do meio ambiente (EMBRAPA I PDE apud BARBIERI; SIMANTOB, 2007, p. $61)$. 
Durante os anos 90, a Embrapa intensificou seu relacionamento com 0 mercado. Houve uma reformulação da política de P\&D de modo que esta passasse a traduzir as finalidades da sociedade em objetivos de projetos de pesquisa. Em 1992 foi criado o Sistema de Planejamento Embrapa (SEP), que foi a iniciativa para tentar operacionalizar o modelo de programação de P\&D orientado pela demanda e para tentar aproximar a empresa de seus clientes. Esse sistema introduziu várias inovações no modelo de gestão, dentre elas destacam-se a prospecção de demandas, o conceito de validação de tecnologia, a ênfase em eficiência e eficácia, a gestão de projetos e de portfólio (CASTRO et al.,1994 apud BARBIERI; SIMANTOB, 2007, p. 62). Essas mudanças geraram um espírito de equipe para soluções de problemas e o desenvolvimento de competência de transferência de tecnologia.

Em 1994 o planejamento de P\&D foi consolidado no II Plano Diretor Embrapa. Sua elaboração exigiu a análise de cenários para a identificação das ameaças e oportunidades, dos pontos fortes e fracos, e consequentemente exigiu a reformulação de sua missão e de seus objetivos. Sua missão passou a ser: "gerar, promover e transferir conhecimentos e tecnologias para o desenvolvimento sustentável dos segmentos agropecuário, agroindustrial e florestal, em benefício da sociedade" (EMBRAPA II PDE, 1994 apud BARBIERI; SIMANTOB, 2007, p. 63)

Durante esse período enfatizou-se também a promoção da imagem institucional da Embrapa, por meio da adoção da Política de Comunicação. Essa política buscava informar a sociedade sobre as ações da instituição e também de perceber as necessidades do mercado. Foi também implementado o Sistema de Planejamento, Acompanhamento e Avaliação dos Resultados do Trabalho Individual (SAAD-RH) visando o acompanhamento e avaliação das atividades planejadas.

Em 1996, foi implementado o Sistema de Avaliação e Premiação de Resultados (SAPRE) visando à busca da eficiência e eficácia, além de motivar equipes e empregados a produzir mais resultados e com maior qualidade. No ano seguinte, introduziu-se a Política de Propriedade Intelectual, que trouxe resultados expressivos para a empresa em relação a obtenção de patentes e ao recebimento de royalties.

O III Plano Diretor Embrapa foi criado voltado para a transferência de tecnologia e para o aumento das receitas próprias. Suas diretrizes tiveram a preocupação de reorientar as ações da empresa para superar os desafios causados 
pelas mudanças globais, tais como a globalização, a preocupação com o meio ambiente e a reforma do Estado. A nova missão da Embrapa passou a ser:

Viabilizar soluções para o desenvolvimento sustentável do agronegócio brasileiro por meio de geração, adaptação e transferência de conhecimentos e tecnologias, em benefício da sociedade. A missão será cumprida levando-se em conta a promoção do agronegócio brasileiro em consonância com as políticas governamentais e as expectativas do mercado (EMBRAPA III PDE, 1998 apud BARBIERI; SIMANTOB,2007, p.65).

Em 2002, ocorreu a substituição do Sistema Embrapa de Planejamento (SEP) pelo Sistema Embrapa de Gestão (SEG). Essa substituição trouxe alterações no sistema de planejamento de pesquisa, com o objetivo de executar o ciclo completo da gestão de projetos. Assim, o SEG contempla as etapas de planejamento, execução, acompanhamento, avaliação, realimentação e cronograma de liberação de recursos financeiros para os projetos. Com isso, a empresa busca maior transparência e flexibilidade organizacional.

A criação do IV Plano Diretor Embrapa teve como base o estudo sobre Cenários do Ambiente de Atuação das Organizações Públicas de Pesquisa e Desenvolvimento para o agronegócio brasileiro, no horizonte de 10 anos (20022012). Com isso, sua missão passou a ditar diretrizes relacionadas ao desenvolvimento sustentável.

Viabilizar soluções para o desenvolvimento sustentável do espaço rural, com foco no agronegócio, por meio da geração, adaptação e transferência de conhecimentos e tecnologias, em benefício dos diversos segmentos da sociedade brasileira. A Missão será cumprida em consonância com as políticas governamentais, enfatizando a inclusão social, a segurança alimentar, as expectativas do mercado e a qualidade do meio ambiente (EMBRAPA, IV PDE, 2004 BARBIERI; SIMANTOB,2007, p.65).

A formulação do V Plano Diretor Embrapa se iniciou em meados de 2007, com o objetivo de fazer uma reflexão estratégica de mais longo alcance. Em 2023, a Embrapa comemora cinqüenta anos de sua criação, com uma trajetória de sucesso. Visando a sustentabilidade dessa trajetória, o V PDE constrói uma visão de estratégias de longo prazo para ajudar nas decisões de curto e médio prazo. Para isso, foi feito um planejamento mais especificado para os próximos quatro anos (2008-2011) e um planejamento de longo prazo no horizonte de 2008 a 2023. Para dá base a esse novo planejamento, foi utilizado, além do estudo sobre Cenários do Ambiente de Atuação das Organizações Públicas de Pesquisa e Desenvolvimento 
para o agronegócio brasileiro, no horizonte de 10 anos (2002-2012), o estudo Cenários do Ambiente de Atuação das Instituições Públicas e Privadas de PD\&I para o Agronegócio e o Desenvolvimento Rural Sustentável no Horizonte 2023, realizado pela Rede de Inovação e Prospecção Tecnológica para o Agronegócio do Brasil (RIPA).

O V PDE introduziu a palavra inovação em sua missão, buscando consolidar a imagem da empresa como de pesquisa, desenvolvimento e inovação (PD\&l), ou seja, empresa que abrange todas as etapas do processo de inovação, desde a geração de novos produtos, serviços e processos até a transferência das tecnologias geradas, dando efetiva aplicabilidade à tecnologia. Sua missão atual é: "viabilizar soluções de pesquisa, desenvolvimento e inovação para a sustentabilidade da agricultura, em benefício da sociedade brasileira" (EMBRAPA, V PDE, 2008, p.18).

O quadro 3 representa um resumo das principais regulamentações ocorridas ao longos desses anos na Embrapa.

\begin{tabular}{|c|c|l|}
\hline Instrumento & Data & \multicolumn{1}{|c|}{ Providência } \\
\hline Lei n. 5.851 & $07 / 12 / 1972$ & $\begin{array}{l}\text { Cria a Empresa Brasileira de Pesquisa } \\
\text { Agropecuária (Embrapa) empresa pública } \\
\text { vinculada ao Ministério da Agricultura, Pecuária e } \\
\text { Abastecimento, dotada de personalidade jurídica de } \\
\text { direito privado, com patrimônio próprio, autonomia } \\
\text { administrativa e financeira. }\end{array}$ \\
\hline Decreto n. 99.916 & $17 / 10 / 1990$ & $\begin{array}{l}\text { Delega à Embrapa a coordenação do Sistema } \\
\text { Brasileiro de Assistência Técnica e Extensão rural } \\
\text { (SIBRATER) }\end{array}$ \\
\hline Lei n. 8.171 & $17 / 01 / 1991$ & $\begin{array}{l}\text { Cria o Sistema Nacional de Pesquisa Agropecuária } \\
\text { (SNPA) }\end{array}$ \\
\hline Deliberação n. 015/92 & $24 / 08 / 1992$ & Ajustes no Modelo Institucional da Embrapa \\
\hline Deliberação n. 016/92 & $24 / 08 / 1992$ & Cria o Sistema Embrapa de Planejamento (SEP) \\
\hline Deliberação n. 014/95 & $04 / 10 / 1995$ & $\begin{array}{l}\text { Crio o Sistema de Planejamento, Acompanhamento } \\
\text { e Avaliação dos Resultados do Trabalho Individual } \\
\text { (SAAD-RH) }\end{array}$ \\
\hline Deliberação n. 010/96 & $10 / 04 / 1996$ & Aprova a marca Embrapa \\
\hline Deliberação n. 037/96 & $18 / 12 / 1996$ & $\begin{array}{l}\text { Cria o Sistema de Avaliação e Premiação por } \\
\text { Resultados (SAPRE) }\end{array}$ \\
\hline
\end{tabular}




\begin{tabular}{|l|l|l|}
\hline Resolução Normativa n. 032/99 & $25 / 08 / 1999$ & Cria o Modelo de Gestão Estratégica (MGE) \\
\hline Resolução Normativa n. 024/01 & $30 / 09 / 2001$ & $\begin{array}{l}\text { Aprova a norma: Siglas, Definições e Referências } \\
\text { do SAPRE }\end{array}$ \\
\hline Resolução Normativa n. 013/02 & $19 / 12 / 2002$ & $\begin{array}{l}\text { Aprova normas do Manual do Sistema Embrapa de } \\
\text { Gestão - SEG (entre elas, do Plano Diretor da } \\
\text { Embrapa - PDE; Plano Diretor da Unidade - PDU; } \\
\text { Modelo de Gestão Estratégica da Embrapa - MGE) }\end{array}$ \\
\hline
\end{tabular}

Quadro 3 - Principais regulamentações da Embrapa

Fonte: Embrapa apud Barbieri e Simantob, 2007

\subsection{Sistema Embrapa de Gestão (SEG)}

O Sistema Embrapa de Gestão (SEG) é um sistema de planejamento de pesquisa que tem o propósito de contemplar o ciclo completo da gestão de projetos de P\&D. Ou seja, definir os processos de planejamento, indução, execução, acompanhamento, avaliação e realimentação das atividades de P\&D, comunicação empresarial, transferência de tecnologia e desenvolvimento institucional. Além disso, o SEG também visa organizar as atividades da empresa, integrando os diferentes níveis de gestão estratégica, tática e operacional.

O SEG permite a visão sistêmica da gestão da empresa e prevê mecanismos para a gestão contínua da carteira de projetos e processos, garantindo ampla participação de atores internos e de parceiros da Embrapa no processo.

Esse sistema é composto por três subsistemas: subsistema de gestão estratégica, subsistema de gestão tática e subsistema de gestão operacional. Cada um deles possui suas atribuições principais, porém agem de maneira integrada. A estrutura do SEG está representada na figura 10.

Os principais objetivos do subsistema de gestão estratégica são: organizar e implementar processos prospectivos para a construção e revisão sistemática da visão estratégica da empresa, definir os rumos e as intenções estratégicas, consolidando as propostas do Plano Diretor Embrapa (PDE), e definir e revisar o foco do negócio da empresa, priorizando os temas de pesquisa para as atividades da empresa. Portanto, seus objetivos estão concentrados na primeira parte do processo de inovação, ou seja, nas atividades de busca de demandas. 
Já em relação ao subsistema de gestão tática, seus objetivos estão mais relacionados com a fase de seleção, de acompanhamento e avaliação do processo de inovação. Seus objetivos são: compor e gerir a carteira de projetos e processos da empresa, implementar e gerir instrumentos de indução para compor a carteira de projetos e processos, e implementar mecanismos para a gestão contínua da carteira de projetos e processos, induzindo o compartilhamento de recursos, capacidade intelectual e infra-estrutura interna e de parceiros.

A fase de efetiva elaboração e execução dos projetos que compõem a carteira de projetos e processos da empresa é de competência do subsistema de gestão operacional. O principal objetivo desse subsistema é elaborar, gerir e executar os projetos e processos de pesquisa alinhados com a estratégia global da empresa, considerando as diretrizes fixadas no PDE e pela agenda nacional.

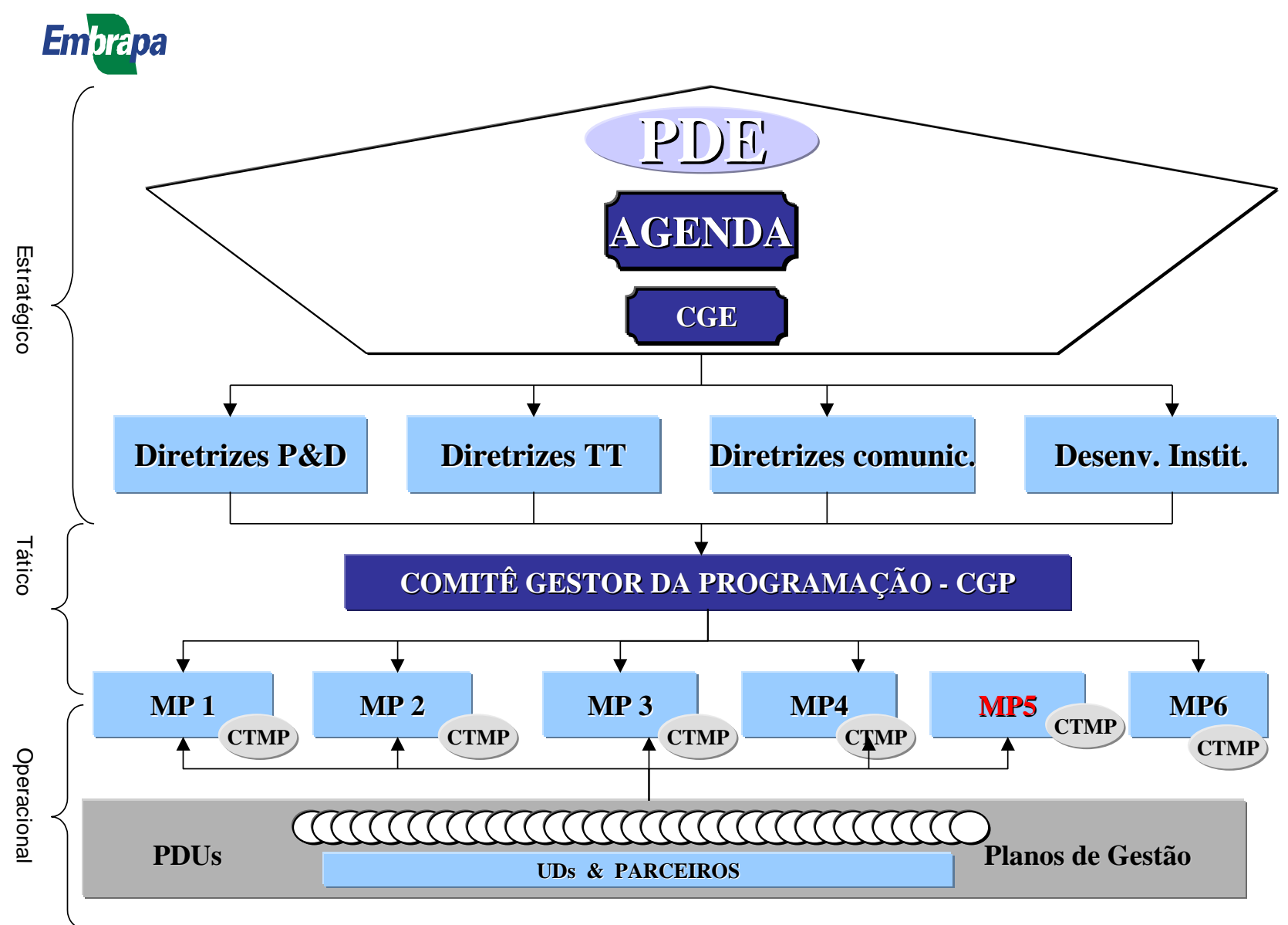

Figura 10 - Estrutura do Sistema Embrapa de Gestão (SEG)

Fonte: Embrapa, Manual do SEG, 2004

Cada uma das funções estabelecidas para o subsistema de gestão estratégica, para o subsistema de gestão tática e para o subsistema de gestão 
operacional é executada por um colegiado do SEG. A figura 11 representa a estrutura dos colegiados que atuam em cada um dos subsistemas.

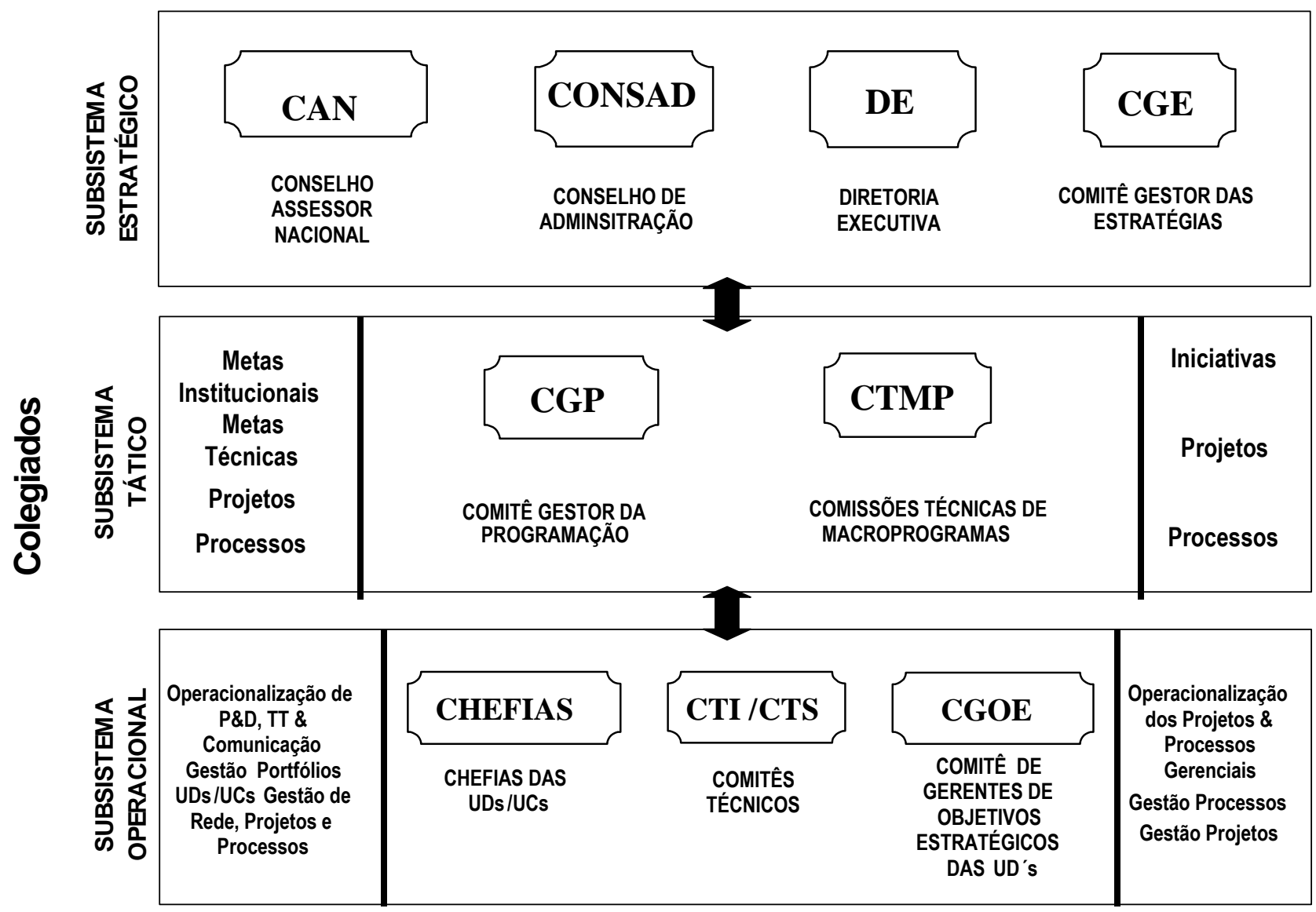

Figura 11- Estrutura dos colegiados do SEG

Fonte: Embrapa, Manual do SEG, 2004

O processo de gestão da Embrapa ocorre por meio de macroprogramas (MP), os quais são instrumentos gerenciais para a operacionalização da programação estratégica da empresa. Os macroprogramas têm o propósito de compor e gerir a carteira de projetos e processos, priorizar os recursos alocados e garantir qualidade técnica, eficiência, eficácia e a avaliação sistemática da carteira.

Cada macroprograma possui projetos, fontes de financiamento e formas de indução de projetos específicos. Além disso, possuem duração indeterminada e um gestor próprio, que é assessorado pela Comissão Técnica de Macroprogramas (CTMP). A carteira de projetos e processos de cada macroprograma é financiada por recursos da Embrapa, recursos extra-orçamentários (por exemplo, quando há convênios ou contratos) e/ou por outras fontes externas que financiem atividades cobertas pela programação da Embrapa. 
Atualmente, a estratégia do SEG é composta por seis macroprogramas, os quais são alinhados a agenda nacional, as diretrizes e aos objetivos contidos no $\mathrm{V}$ PDE (vigente de 2008 a 2011). Cada macroprograma possui linhas temáticas relacionadas aos temas do macroprograma que guiarão os projetos. Os seis temas vigentes na Embrapa são:

- Macroprograma 1 (MP1): Grandes Desafios Nacionais

- Macroprograma 2 (MP2): Competitividade e Sustentabilidade Setorial

- Macroprograma 3 (MP3): Desenvolvimento Tecnológico Incremental do Agronegócio

- Macroprograma 4 (MP4): Transferência de Tecnologia e Comunicação Empresarial

- Macroprograma 5 (MP5): Desenvolvimento Institucional

- Macroprograma 6 (MP6): Apoio ao Desenvolvimento da Agricultura Familiar e à Sustentabilidade do Meio Rural

O funcionamento completo do processo de gestão do SEG ocorre de acordo com as seguintes etapas:

1. Primeiramente, inicia-se a elaboração do Plano Diretor da Embrapa (PDE) e o das Unidades Descentralizadas (PDU) que guiarão a empresa pelos próximos quatro anos. O PDE é elaborado pela Secretaria de Gestão e Estratégia (SGE) e deve ser aprovado pela Diretoria Executiva (DE) e pelo Conselho de Administração (CONSAD). Já o PDU é elaborado pelas chefias de cada unidade apoiado por seu Comitê Técnico (CTIs), portanto, cada unidade possui o seu próprio plano diretor. Esse PDU deve ser aprovado pela DE.

2. Com base no PDE, nos PDUs e em estudos prospectivos, o Comitê Gestor da Estratégia (CGE) elabora uma proposta de diretrizes para a composição da agenda institucional, que deve ser validada pelo Conselho Assessor Nacional (CAN). Após ser validada, a agenda institucional segue para nova aprovação, agora definitiva, a ser feita pela DE e pelo CONSAD.

3. Em seguida, a DE e o CONSAD elaboraram as metas institucionais baseadas no PDE e na agenda institucional aprovadas.

4. Tendo sido estabelecidas as metas institucionais, o Comitê Gestor da Programação (CGP) negocia com a DE a alocação dos recursos financeiros necessários para a execução da programação. Além disso, o CGP baseado 
nas metas institucionais, define as metas técnicas e a carteira de projetos a serem acompanhados, os procedimentos de indução e a alocação de recursos para cada um dos macroprogramas.

5. Posteriormente, cada gestor de macroprograma inicia o processo periódico de indução de projetos para a formação da carteira de projetos. As equipes do macroprograma elaboram as propostas de projeto ou processo e as encaminham para o gestor do macroprograma. Este a encaminha para a análise e aprovação técnica pelo CTIs, para conseqüente priorização dos projetos.

6. As carteiras de projetos e processos que forem tecnicamente aprovados serão analisadas em conjunto pelo CGP, visando garantir $O$ balanço estratégico e a consolidação do esforço global da empresa. A programação aprovada pelo CGP é homologada pela DE.

7. Após a homologação da programação, inicia-se a execução dos projetos componentes da carteira dos macroprogramas. A execução dos projetos é feita pelos líderes e pelas equipes dos macroprogramas nas Unidades Descentralizadas.

8. Periodicamente é feita a avaliação dos projetos e processos que estão sendo executados. Essa avaliação é feita tanto pelo CTI de cada Unidade, como também pelo CTPM. Ela visa identificar os resultados, propor correções em sua execução ou até mesmo cancelar o projeto ou processo em execução.

\subsection{Seleção de projetos no Sistema Embrapa de Gestão (SEG)}

O procedimento citado na seção anterior descreve a fase completa da gestão de projetos de P\&D feita na Embrapa. Porém, o principal objetivo deste trabalho é analisar especificamente 0 processo de seleção desses projetos de P\&D que formarão a carteira de projetos e processos da Embrapa para a execução no período determinado.

Antes de abordar especificamente o processo de seleção, é importante saber que na Embrapa existem categorias de projetos de P\&D, as quais são baseadas no grau de complexidade do tema ou problema abordado. Assim, há uma divisão dos 
projetos de P\&D em três categorias de projetos: projetos em rede, projeto temático e projeto disciplinar/interdisciplinar.

Os projetos em rede são aquelas pesquisas que exigem um conjunto coordenado de esforços que transcendem os limites disciplinares de um único projeto e também a capacidade técnica e a infra-estrutura disponível em uma única organização. Os projetos que são organizados dessa forma são inter-conectados por um plano de gestão que busca o alinhamento de atividades e ações para o alcance dos objetivos comuns.

Já os projetos temáticos são aquelas pesquisas de caráter aplicado ou estratégico, de natureza temática ou interdisciplinar, e que o conjunto de ações pode ser englobado de forma ordenada e lógica em um único projeto. No caso da categoria de projeto disciplinar/interdisciplinar, as pesquisas são voltadas para inovações que exijam equipes de alta especialização, mas sem a necessidade de arranjos organizacionais complexos, e que tenham execução em períodos de curto e médio prazo.

Os projetos da área de transferência de tecnologia, comunicação empresarial e desenvolvimento institucional são divididos em apenas duas dessas categorias. Eles podem ser da categoria projeto temático ou da de projeto disciplinar/interdisciplinar.

Cada macroprograma é voltado para um tipo dessas categorias de projetos. Assim, se o projeto não atender aos requisitos da categoria do macroprograma no qual está inserido, ele já é eliminado do processo seletivo. O Macroprograma 1 tem como tema principal Grandes Desafios Nacionais. Ele tem por objetivo a gestão de uma carteira de projetos de pesquisa, desenvolvimento e inovação (PD\&I) de base científica elevada, de caráter transdisciplinar e multi-institucional. Deve ser composto por pesquisas de caráter estratégico e que exijam arranjos institucionais complexos ou grandes redes (categoria de projeto em rede) e a aplicação intensiva de recursos para a sua execução, pois buscam alcançar avanços tecnológicos radicais, estabelecer novos paradigmas para o conhecimento e para o padrão tecnológico do agronegócio brasileiro, superar desequilíbrios sociais e alcançar ou consolidar vantagens competitivas e sustentabilidade no agronegócio brasileiro. Sua estrutura de pesquisa em rede está representada na figura 12. 


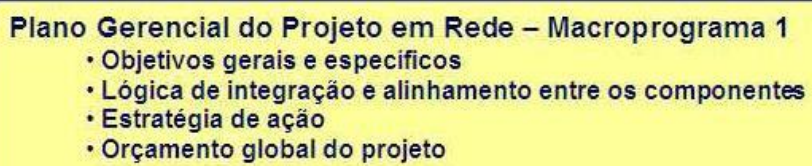

- Lógica de integração e alinhamento entre os componentes

- Estratégia de ação

- Orçamento global do projeto

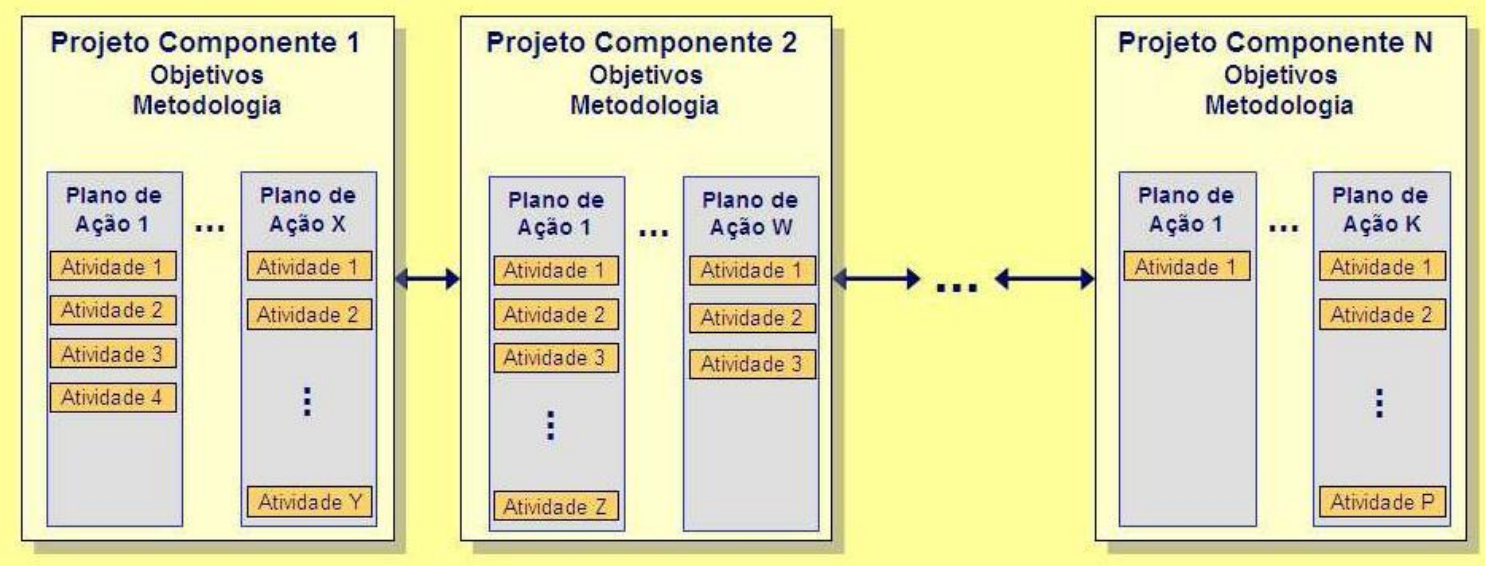

Figura 12 - Estrutura típica dos projetos do Macroprograma 1

Fonte: Embrapa, 2009

Para o Macroprograma 2, que tem como tema principal Competitividade e Sustentabilidade Setorial, busca-se pesquisas de caráter aplicado, estratégico ou básico, de natureza temática ou interdisciplinar, de médio prazo e que exijam a organização de grupos, equipes interativas e redes para a sua execução (categoria de projeto temático). Seu objetivo é obter avanços significativos e inovadores no conhecimento e no padrão tecnológico do agronegócio brasileiro; e subsidiar políticas públicas voltadas para estimular a competitividade, a sustentabilidade do agronegócio e o desenvolvimento econômico e social do país. A estrutura típica dos projetos pertencentes a esse macroprograma está representada na figura 13.

Já o Macroprograma 3 tem como tema principal o Desenvolvimento Tecnológico Incremental do Agronegócio. Tem o objetivo de apoiar o aperfeiçoamento tecnológico contínuo do agronegócio e atividades correlatas, dando ênfase a projetos de transferência tecnológica, com atividades de desenvolvimento, validação e acabamento de tecnologias, desenvolvimento de protótipos além de unidades demonstrativas e outras atividades afins que não tenham caráter rotineiro. Prioriza projetos de curto e médio prazos, que possam ser executados por meio de arranjos simples e pouco intensivos em aplicação de recursos (categoria de projeto disciplinar/interdisciplinar). A estrutura dos projetos componentes do macroprograma 3 está representada na figura 14. 
Projeto do Macroprograma 2

- Objetivos gerais e específicos

- Lógica de integração e alinhamento entre os planos de ação

- Metodologia

- Estratégia de ação

- Orçamento global do projeto

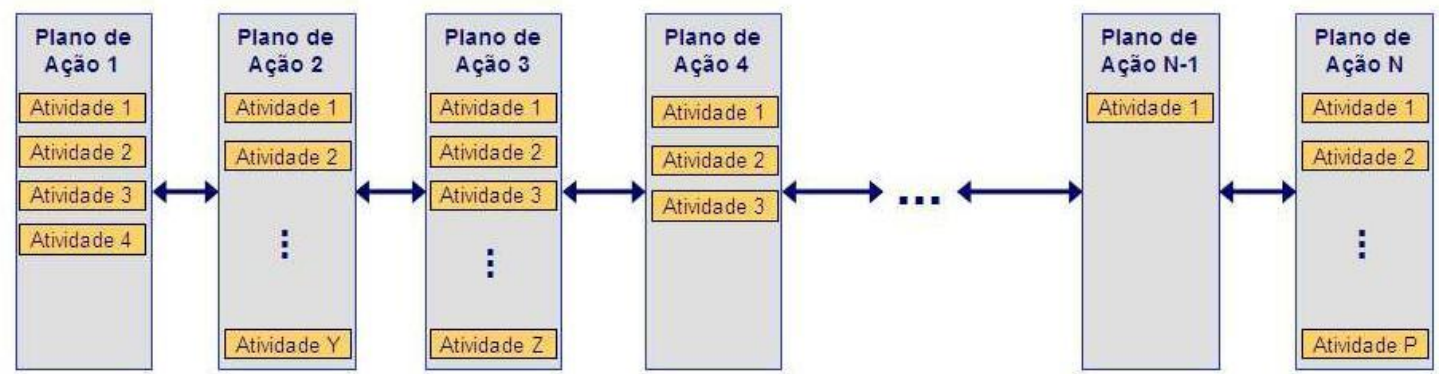

Figura 13 - Estrutura típica dos projetos do Macroprograma 2

Fonte: Embrapa, 2009

\section{Projeto do Macroprograma 3 \\ - Objetivos gerais e específicos \\ - Lógica de integração e alinhamento entre os planos de ação \\ - Metodologia \\ - Estratégia de ação \\ - Orçamento global do projeto}

\begin{tabular}{|c|c|c|}
\hline $\begin{array}{l}\text { Plano de } \\
\text { Ação } 1\end{array}$ & $\begin{array}{l}\text { Plano de } \\
\text { Ação } 2\end{array}$ & $\begin{array}{c}\text { Plano de } \\
\text { Ação } 3\end{array}$ \\
\hline Atividade 1 & \begin{tabular}{|l|} 
Atividade 1 \\
\end{tabular} & Atividade 1 \\
\hline Atividade 2 & \begin{tabular}{|l|} 
Atividade 2 \\
\end{tabular} & Atividade 2 \\
\hline \multirow[t]{3}{*}{ Atividade 3} & & Atividade 3 \\
\hline & : & ; \\
\hline & Atividade $Y$ & Atividade Z \\
\hline
\end{tabular}

Figura 14 - Estrutura típica de projetos do Macroprograma 3 Fonte: Embrapa, 2009

O tema principal do macroprograma 4 é Transferência de Tecnologia e Comunicação Empresarial. Esse macroprograma busca desenvolver a integração entre a atividade de PD\&I e o mercado, e aprimorar o relacionamento da Embrapa com seus públicos de interesse e com a sociedade. Os projetos devem ser de caráter aplicado, de natureza temática ou interdisciplinar, e que priorizem a 
execução em núcleos especializados, equipes interativas ou redes (categoria de projeto temático). A estrutura típica desses projetos está representada na figura 15.

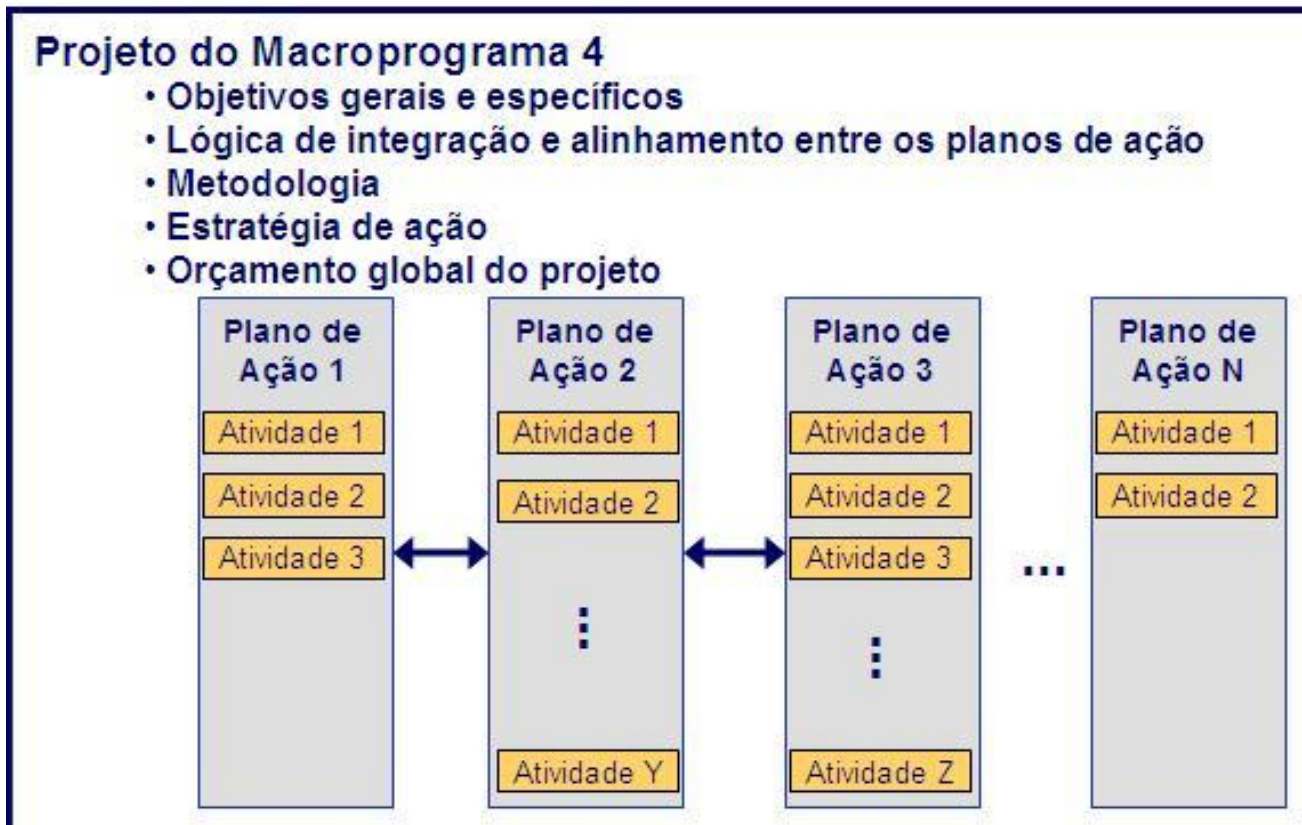

Figura 15 - Estrutura típica dos projetos do Macroprograma 4 Fonte: Embrapa, 2009

No caso do macroprograma 5, que tem como tema principal Desenvolvimento Institucional, o objetivo é buscar a melhoria dos resultados, o aumento da efetividade organizacional, o desenvolvimento e a utilização plena do potencial dos talentos humanos da empresa. Os projetos devem ter caráter intra e interinstitucional, que integrem equipes multi-institucionais e que busquem avanços técnicos ou administrativos radicais ou incrementais, para o estabelecimento de novos paradigmas no desenvolvimento institucional. A estrutura típica dos projetos desse macroprograma está representada na figura 16. 


\section{Projeto do Macroprograma 5}

- Objetivos gerais e específicos

- Metodologia

- Estratégia de ação

- Orçamento global do projeto

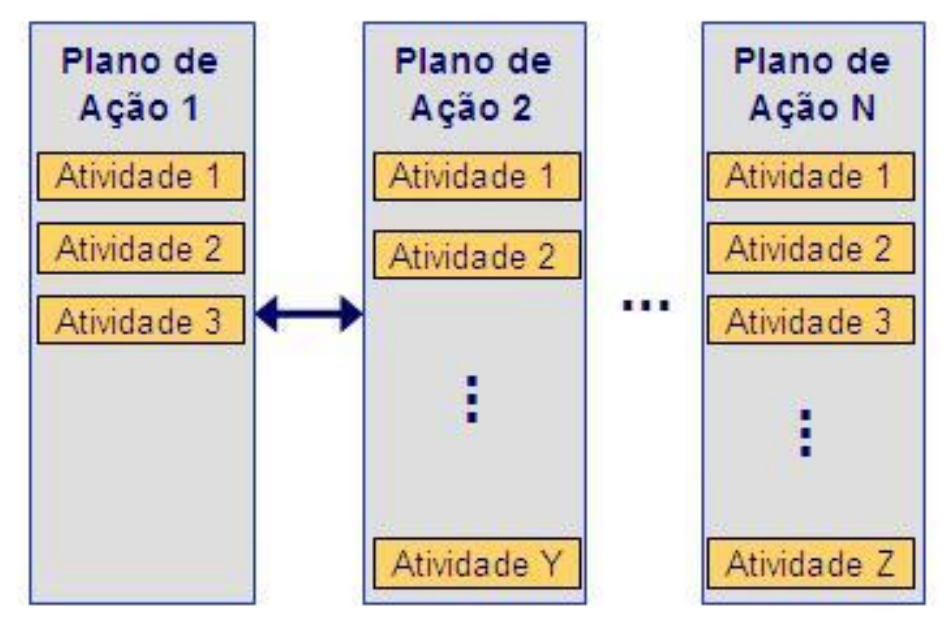

Figura 16 - Estrutura típica dos projetos do Macroprograma 5 Fonte: Embrapa, 2009

Finalmente, o macroprograma 6 tem como tema principal o Apoio ao Desenvolvimento da Agricultura Familiar e à Sustentabilidade do Meio Rural. Seu objetivo é fornecer suporte a iniciativas de desenvolvimento sustentável da agricultura familiar e de comunidades tradicionais. Os projetos devem fornecer métodos, instrumentos e meios para apoiar políticas públicas e programas mais específicos de desenvolvimento, fomento, capacitação e socialização de conhecimentos e tecnologias agropecuárias, que busquem a inclusão social dos segmentos envolvidos com a produção de base familiar, assentamentos de reforma agrária e comunidades tradicionais. São projetos multi-institucionais e interdisciplinares, que devem ser executados em núcleos especializados, com equipes interativas ou em redes, utilizando metodologia participativa. A estrutura desses projetos está representada na figura 17. 


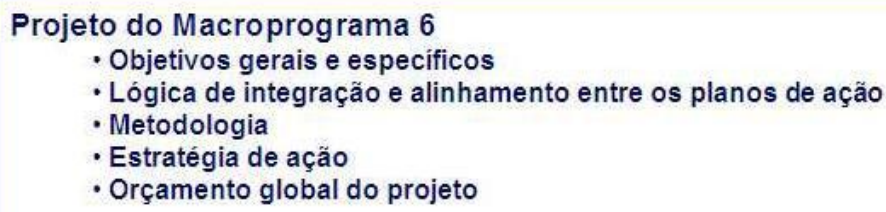

- Lógica de integração e alinhamento entre os planos de ação

- Metodologia

- Estratégia de ação

- Orçamento global do projeto

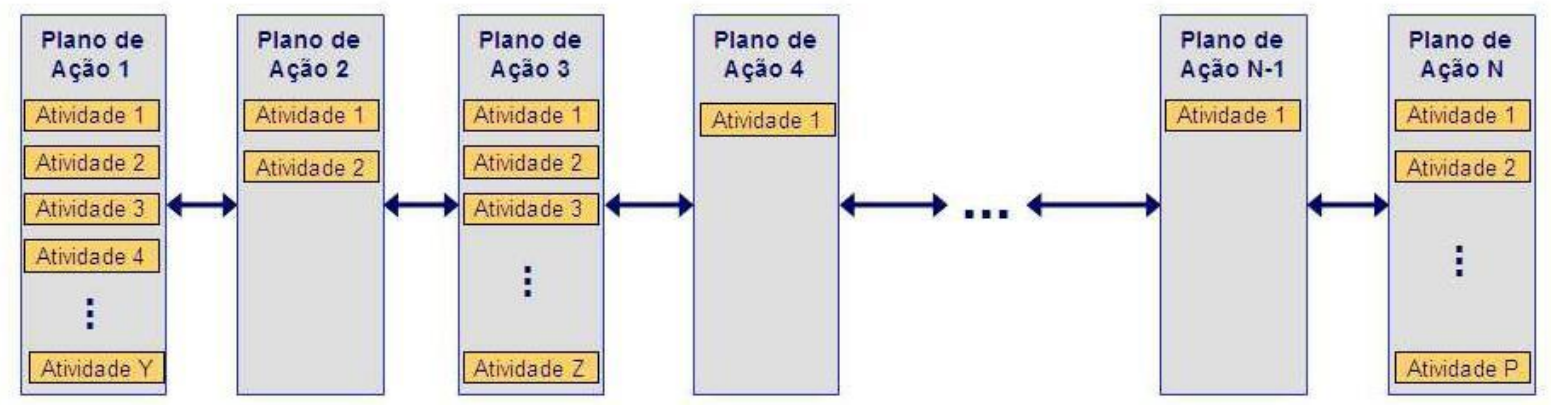

Figura 17 - Estrutura típica dos projetos do Macroprograma 6 Fonte: Embrapa, 2009

Com base em todos esses fatores citados, fica claro que cada macroprograma possui suas características, orçamentos financeiros específicos, duração, suas metas e objetivos a serem alcançados. Todos esses aspectos estão relatados no Edital ou Chamada dos Macroprogramas (anexo A), que é o meio utilizado para publicar as linhas de pesquisa de interesse da Embrapa, juntamente com os aspectos relevantes para o processo seletivo. Essas Chamadas são feitas semestralmente. Após sua publicação, inicia-se efetivamente o processo de indução de projetos dentro da empresa.

Após o conhecimento da Chamada, as equipes de pesquisadores da Embrapa começam a elaborar as propostas de projetos ou processos baseado nas linhas temáticas do macroprograma de que fazem parte. São aceitas tanto propostas, como pré-propostas e cartas-consulta. O formulário de proposta deve ser preenchido no InfoSEG, o qual utiliza ferramentas de autenticação eletrônica e emite recibos. Em seguida, deve esse formulário deve ser enviado para avaliação do Comitê Técnico (CTI nas Unidades e CTS na Sede). As propostas que forem aprovadas, seguem para a avaliação do gestor do macroprograma.

As propostas e pré-propostas de projetos devem conter dados relativos ao resumo do projeto, tais como caracterização do problema, objetivos, plano de ação e resultados esperados; equipe do projeto, que deve conter o nome dos pesquisadores e suas funções dentro do projeto; custeio do projeto, caso tenha 
outras fontes de financiamento, tais como parcerias, identificar o nome das instituições; e o orçamento estimado do projeto. Os membros da equipe de pesquisadores do projeto devem está com seu curriculum vitae atualizado na Plataforma Lattes de Currículos do Conselho Nacional de Desenvolvimento Científico e Tecnológico (CNPq) há menos de seis meses da data da Chamada, caso contrário a proposta será desqualificada.

Após expirada a data limite para envio de propostas (segundo o calendário especificado na Chamada), as propostas enviadas serão avaliadas visando a priorização e seleção dessas. Primeiramente, o gestor de cada macroprograma avalia as propostas específicas do seu macroprograma de acordo com a conformidade com a Chamada. Nessa fase, ele avalia os seguintes aspectos: áreas e linhas temáticas, elegibilidade institucional do proponente e dos participantes, aderência aos conceitos do Macroprograma e às características dos projetos, preenchimento correto dos campos dos formulários da pré-proposta/proposta e os currículos atualizados dos pesquisadores na Plataforma Lattes de Currículos do CNPq.

As propostas que atendem aos requisitos citados anteriormente, são encaminhadas para a avaliação de mérito técnico. Essa avaliação de mérito técnico é feita por consultores ad-hoc, ou seja, doutores de reconhecida produção científica na área, externos à Embrapa e que são escolhidos na base Lattes do CNPq. Essa avaliação é feita por meio do InfoSEG, o qual emite os pareceres técnicos dos projetos após serem avaliados pelos consultores. São estabelecidos escores de relevância para os seguintes aspectos relativos ao mérito técnico-científico (clareza, concisão e objetividade): questões técnico-científicas colocadas; objetivos, metas e estratégias; metodologia, resultados e impactos esperados; ações de transferência de tecnologia; qualificação e experiência das instituições integrantes, da equipe e dos parceiros; adequação dos arranjos sobre a propriedade intelectual; medidas de segurança biológica, pessoal e ambiental; e adequação da proposta orçamentária e duração do projeto.

As propostas juntamente com seus pareceres técnicos são encaminhadas à Comissão Técnica de Macroprograma (CTMP), que é formada por especialistas internos e externos à Embrapa, os quais são nomeados pela Diretoria Executiva (DE). A CTMP avalia os pareceres e recomenda ou não a aprovação das propostas ao Comitê Gestor da Programação (CGP). 
A avaliação final é feita pelo CGP em reuniões ordinárias. O CGP avalia as propostas em relação ao mérito estratégico e tem como referência fundamental os objetivos e diretrizes estratégicos gerais e específicos do Plano Diretor Embrapa (PDE). Assim, procura-se determinar a contribuição de cada proposta de projeto em relação à carteira de projetos em execução na Embrapa, para o cumprimento das metas institucionais da empresa, para gerar impactos em relação à estratégia institucional e para avaliar o custo do projeto em relação aos benefícios institucionais esperados.

Tendo isso em vista, cada pré-proposta e proposta é avaliada determinandose, por meio de escores indicativos de relevância, o grau em que cada proposta de projeto contribuirá para o alcance dos objetivos estratégicos estabelecidos no PDE, avaliando-se isoladamente ou em conjunto os seguintes fatores: qualidade técnica, alinhamento aos objetivos estratégicos, riscos associados à execução do projeto, avanço técnico-científico proposto e potencial de inovação pretendido, e os ganhos previstos para os clientes e beneficiários.

A figura 18 resume esse processo de elaboração, apresentação e avaliação de pré-propostas e propostas feita no SEG.

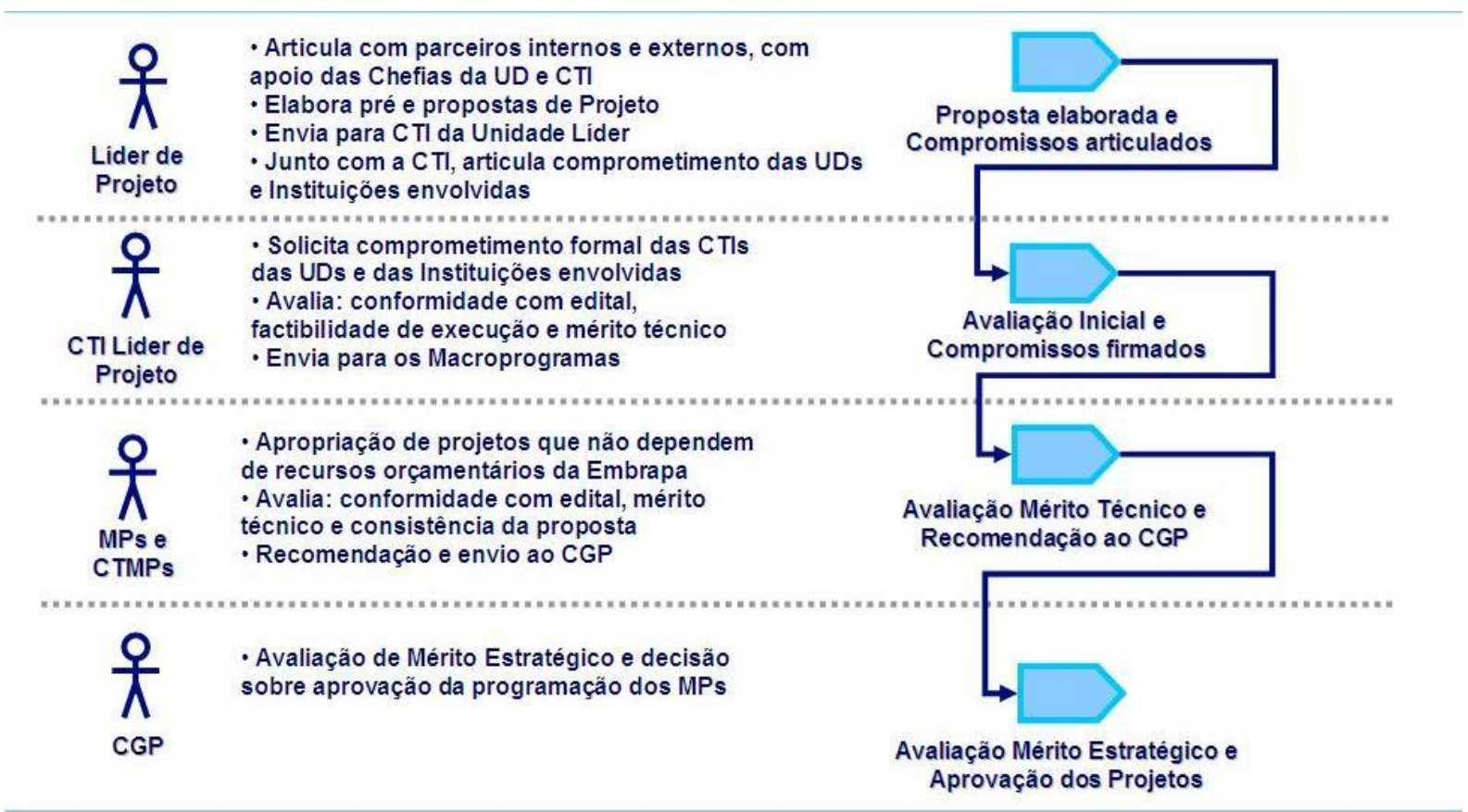

Figura 18 - Esquematização do processo de elaboração, apresentação e avaliação de pré-propostas e propostas no SEG

Fonte: Embrapa, 2009 
Após todos os relatórios emitidos terem sido avaliados, são feitos gráficos dos projetos individuais e em conjunto (gráfico bolhas) que facilitam a escolha dos projetos que formarão a carteira de projetos e processos da Embrapa. O gráfico é feito por macroprograma, e, portanto, é analisado de acordo com as características desse. Um exemplo de gráfico está representado no gráfico 1. Nesse gráfico são avaliados os critérios risco e ganho técnico-científico para os projetos do Macroprograma 2. Quanto maior é o tamanho da bola, maior é a quantidade de recursos exigida pelo projeto. Nesse caso, como os projetos do macroprograma 2 visam projetos de base científica elevada, os projetos com maiores chances de serem aprovados encontram-se nos quadrantes II e III (lado direito do gráfico), porém os outros critérios ainda serão avaliados.

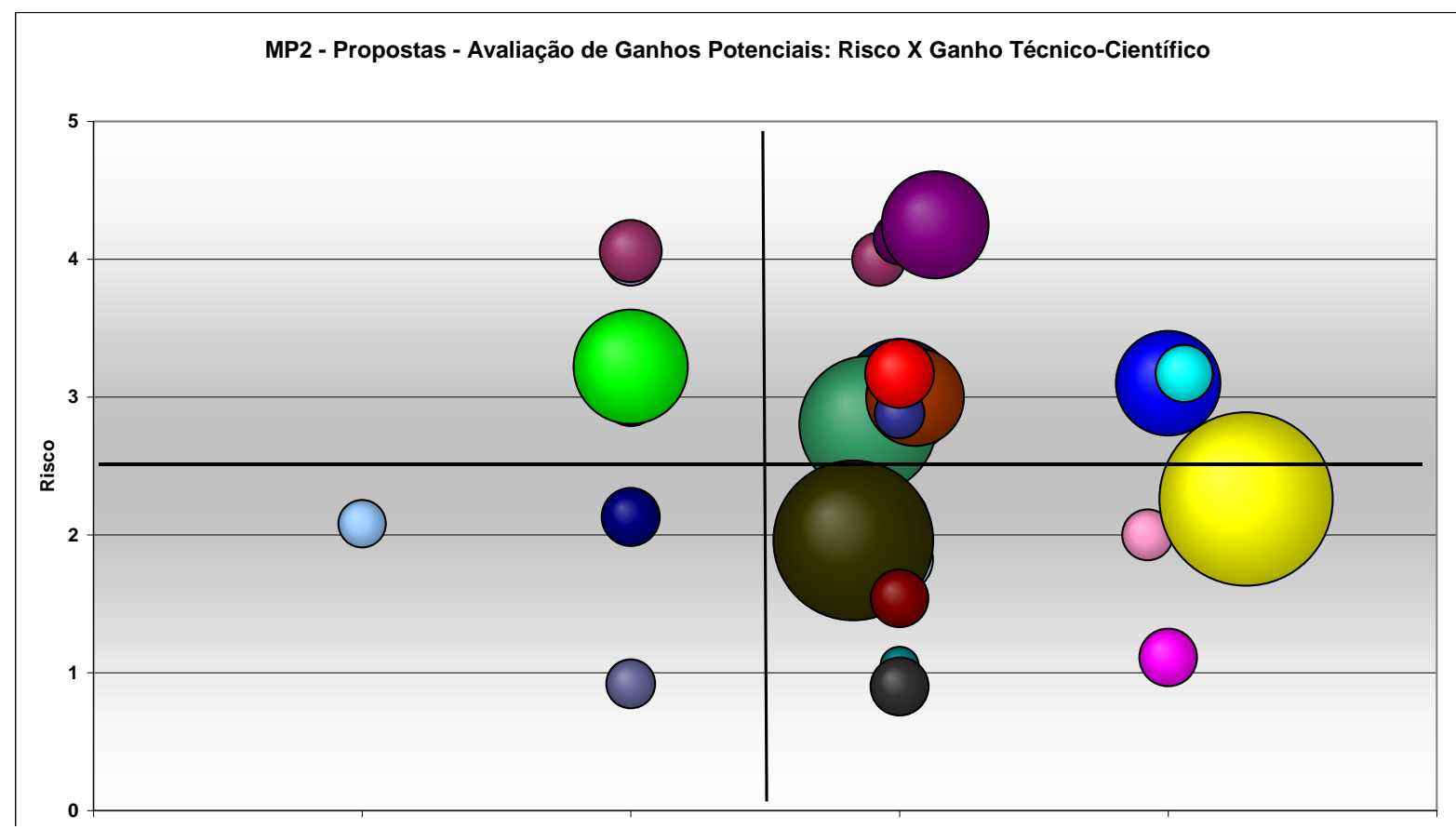

Gráfico 1 - Gráfico bolha com os projetos do Macroprograma 2, avaliando Risco X Ganho técnico-científico

Fonte: Embrapa 


\subsection{Resultados do Sistema Embrapa de Gestão (SEG)}

Em 2008, a programação de pesquisa em execução do Sistema Embrapa de Gestão (SEG) foi realinhada para os objetivos e eixos estratégicos propostos pelo $\mathrm{V}$ Plano Diretor Embrapa (PDE). Os novos objetivos são:

- Objetivo 1 (OE1): garantir a competitividade e sustentabilidade da agricultura brasileira,

- Objetivo 2 (OE 2): atingir um novo patamar tecnológico competitivo em agroenergia e biocombustíveis,

- Objetivo 3 (OE 3): intensificar o desenvolvimento de tecnologias para o uso sustentável de biomas e a integração produtiva das regiões brasileiras,

- Objetivo 4 (OE 4): prospectar a biodiversidade para o desenvolvimento de produtos diferenciados e com alto valor agregado para a exploração de novos segmentos de mercado,

- Objetivo 5 (OE 5): contribuir para o avanço da fronteira do conhecimento e incorporar novas tecnologias, inclusive as emergentes.

O resultado desse realinhamento estratégico foi aprovado na 17. ${ }^{a}$ reunião do Comitê Gestor da Programação (CGP) ocorrida no período de 08 a 11 de dezembro de 2008. Assim, a programação iniciada em 2009 segue as seguintes prioridades de recursos: mais recursos serão investidos visando alcançar o objetivo 4 (prospecção da biodiversidade para novos produtos e segmentos de mercado) e o objetivo 5 (avanços na fronteira do conhecimento), já para os objetivos 1, 2 e 3 haverá redução de recursos para os projetos, conforme mostra o gráfico 2.

Em 2008, o total de recursos disponibilizados para os projetos, atendendo aos seis macroprogramas, a serem executados no período de 2008 a 2012 foi de $R \$$ 109.622.000,00 (cento e nove milhões, seiscentos e vinte e dois mil reais). As tabelas 1 e 2 mostram os recursos disponíveis por macroprograma para os projetos aprovados para execução nos próximos anos. 


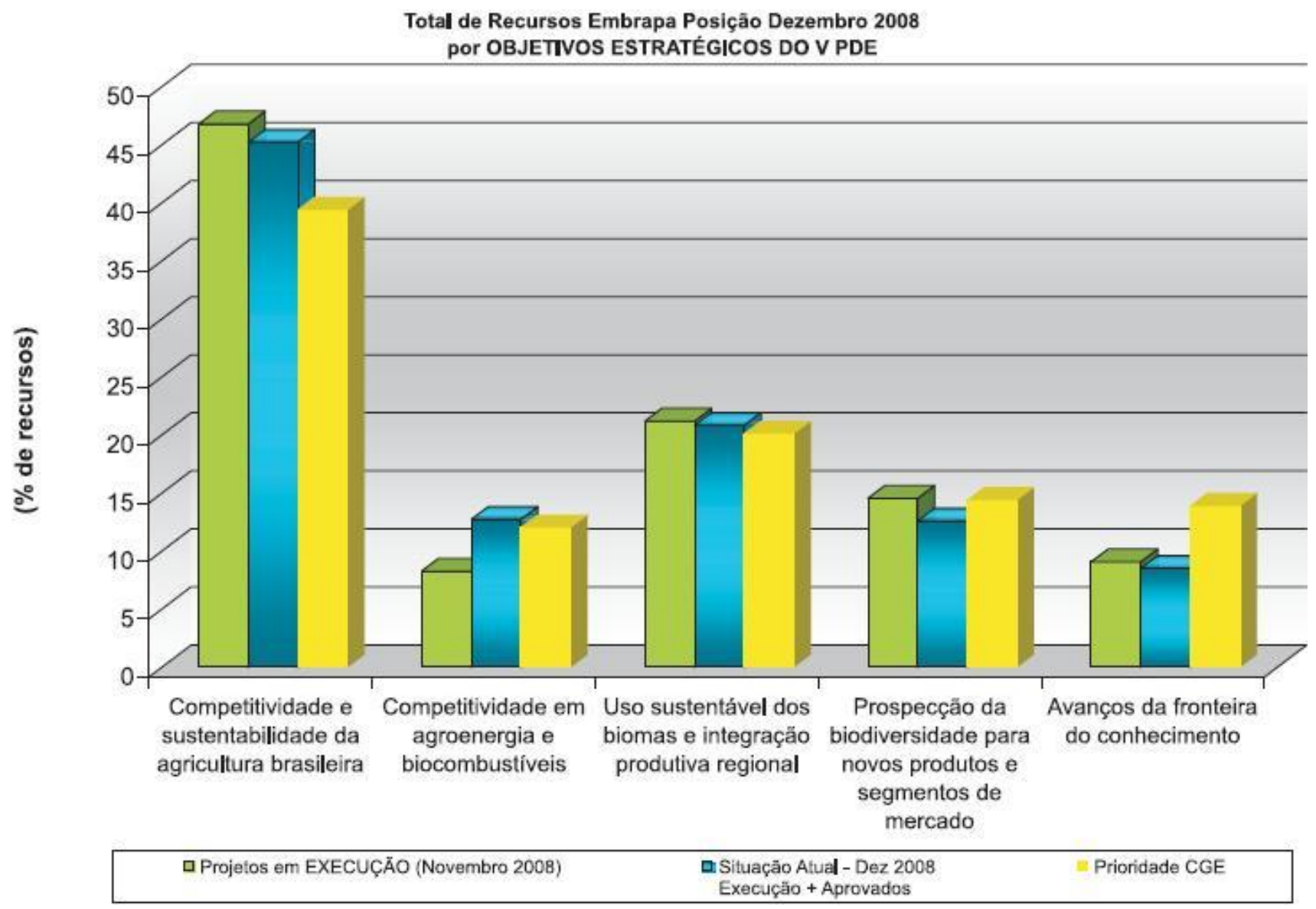

Gráfico 2 - Percentual de recursos disponibilizados para cada objetivo estratégico do V PDE, após o realinhamento aprovado em dezembro de 2008, a ser executado em 2009 Fonte: Embrapa, 2008

\begin{tabular}{|c|c|c|c|c|c|c|c|}
\hline \multicolumn{2}{|c|}{ EDITAL } & \multicolumn{6}{|c|}{ ANO DE EXECUÇÃO } \\
\hline Ano & Edital & MPS & 2009 & 2010 & 2011 & 2012 & Total \\
\hline \multirow{11}{*}{ ర్లి } & \multirow{5}{*}{ - } & 1 & 2.800 .000 & 2.800 .000 & 2.800 .000 & 2.800 .000 & 11.200 .000 \\
\hline & & 2 & 4.480 .000 & 4.480 .000 & 4.480 .000 & 0 & 13.440 .000 \\
\hline & & 3 & 1.232 .000 & 560.000 & 0 & 0 & 1.792 .000 \\
\hline & & 4 & 1.680 .000 & 1.120 .000 & 0 & 0 & 2.800 .000 \\
\hline & & 6 & 1.204 .000 & 1.232 .000 & 1.204 .000 & 0 & 3.640 .000 \\
\hline & 2 & $\begin{array}{c}2 \\
\text { Melhoramento } \\
\text { Genético }\end{array}$ & 3.920 .000 & 3.920 .000 & 3.920 .000 & 3.920 .000 & 15.680 .000 \\
\hline & 3 & 5 & 1.400 .000 & 1.400 .000 & 0 & 0 & 2.800 .000 \\
\hline & \multirow{3}{*}{4} & 1 & 1.250 .000 & 1.250 .000 & 1.250 .000 & 1.250 .000 & 5.000 .000 \\
\hline & & 2 & 475.000 & 1.000 .000 & 525.000 & 0 & 2.000 .000 \\
\hline & & 3 & 500.000 & 250.000 & 0 & 0 & 750.000 \\
\hline & 5 & 2 & 2.500 .000 & 2.500 .000 & 2.500 .000 & 2.500 .000 & 10.000 .000 \\
\hline \multicolumn{3}{|c|}{ TOTAL } & $21.441 .000,00$ & $20.512 .000,00$ & $16.679 .000,00$ & $10.470 .000,00$ & $69.102 .000,00$ \\
\hline
\end{tabular}

Tabela 1 - Recursos disponíveis por macroprograma aprovados em 2008

Fonte: Embrapa, 2008 


\begin{tabular}{|c|c|c|c|c|c|c|c|}
\hline \multicolumn{2}{|c|}{ EDITAL } & \multicolumn{6}{|c|}{ ANO DE EXECUÇÃO } \\
\hline Ano & Edital & MPS & 2009 & 2010 & 2011 & 2012 & Total \\
\hline \multirow{7}{*}{ ర్ } & \multirow{3}{*}{6} & 2 & 1.000 .000 & 3.500 .000 & 3.500 .000 & 2.000 .000 & 10.000 .000 \\
\hline & & 3 & 750.000 & 1.500 .000 & 750.000 & 0 & 3.000 .000 \\
\hline & & 6 & 250.000 & 1.000 .000 & 250.000 & 0 & 1.500 .000 \\
\hline & 7 & $\begin{array}{c}2 \\
\text { Melhoramento } \\
\text { Genético }\end{array}$ & 750.000 & 2.250 .000 & 2.250 .000 & 1.000 .000 & 6.250 .000 \\
\hline & 8 & 4 & 500.000 & 1.500 .000 & 1.500 .000 & 500.000 & 4.000 .000 \\
\hline & 9 & 5 & 750.000 & 1.500 .000 & 750.000 & 0 & 3.000 .000 \\
\hline & 10 & 2 & 1.000 .000 & 4.000 .000 & 4.000 .000 & 1.000 .000 & 10.000 .000 \\
\hline \multicolumn{3}{|c|}{ TOTAL } & $5.000 .000,00$ & $15.250 .000,00$ & $13.000 .000,00$ & $4.500 .000,00$ & $37.750 .000,00$ \\
\hline
\end{tabular}

Tabela 2 - Recursos disponíveis por macroprograma aprovados em 2008

Fonte: Embrapa, 2008

O total de propostas de projetos aprovados durante a $16 .^{\mathrm{a}}$ e a $17 .^{\mathrm{a}}$ reuniões do CGP (ocorridas entre 30 de junho e 4 de julho de 2008, e entre 8 e 11 de dezembro de 2008, respectivamente), para execução no período de 2008 a 2012, foi de 282 propostas, 64 pré-propostas e 8 cartas-consulta. As tabelas 3 e 4 mostram os totais aprovados por reunião.

\begin{tabular}{|l|c|c|c|}
\hline \multicolumn{4}{|c|}{ 16. Reunião do CGP } \\
\hline & Submetidas & Aprovadas & $\%$ Aprovação \\
\hline Propostas & 240 & 152 & $63,33 \%$ \\
\hline Pré-propostas & 75 & 41 & $54,67 \%$ \\
\hline Cartas-consulta & 12 & 6 & $50,00 \%$ \\
\hline Total & 327 & 199 & $60,86 \%$ \\
\hline
\end{tabular}

Tabela 3 - Projetos aprovados na 16. ${ }^{a}$ Reunião do CGP Fonte: Embrapa, 2008

\begin{tabular}{|l|c|c|c|}
\hline \multicolumn{4}{|c|}{ 17. Reunião do CGP } \\
\hline & Submetidas & Aprovadas & $\%$ Aprovação \\
\hline Propostas & 214 & 130 & $60,75 \%$ \\
\hline Pré-propostas & 35 & 23 & $65,71 \%$ \\
\hline Cartas-consulta & 8 & 2 & $25,00 \%$ \\
\hline Total & 257 & 155 & $60,31 \%$ \\
\hline
\end{tabular}

Tabela 4 - Projetos aprovados na 17. ${ }^{a}$ Reunião do CGP

Fonte: Embrapa, 2008

Ao final de 2008, o total de projetos em execução no SEG era de 987 projetos. Dentre esses, 307 projetos eras apropriados, ou seja, possuíam outra fonte de financiamento, tais como Conselho Nacional de Desenvolvimento Científico (CNPq), Financiadora de Estudos e Projetos (FINEP), Fundação Banco do Brasil e BASA. 


\subsection{Análise dos dados segundo as categorias}

Após a descrição do funcionamento da gestão de projetos na Embrapa feita na seção anterior, será feita a análise dos dados segundo as categorias estipuladas pela autora e mencionadas no capítulo de metodologia. A análise será feita separada por categoria, sendo o referencial teórico citado nesta pesquisa utilizado como base para a justificativa das conclusões obtidas.

- Tipo de inovação

A inovação, segundo Tidd, Bessant e Pavitt (2008), pode ser de 4 tipos: produto, processo, posição e paradigma. O SEG pode ser considerado uma inovação de paradigma segundo esta classificação, posto que, segundo esses autores, esse tipo de inovação gera mudanças nos modelos mentais que orientam o que a empresa faz. Com a implementação do SEG, substituiu-se a visão temática do Sistema Embrapa de Planejamento (SEP) para uma abordagem integradora. Além disso, passou-se a executar o ciclo completo de gestão de projetos, desde o planejamento até a realimentação do sistema. Para isso, foi necessária a revitalização do capital humano, revitalização institucional, revitalização financeira e da infra-estrutura. Portanto, houve uma mudança na forma de planejar e de executar a pesquisa, buscando maior eficiência no processo e a garantia de qualidade técnica e científica dos projetos.

- Grau de inovação

O SEG pode ser considerado uma inovação incremental, segundo o conceito de Freeman, pois este tipo de inovação é apenas uma melhoria de algo já existente. O SEG foi adotado em 2002 e é um aprimoramento do SEP, o qual foi a iniciativa para operacionalizar o modelo de programação de P\&D orientado para a demanda. O SEP introduziu inovações tais como a prospecção de demandas, a ênfase na eficiência e na eficácia, e a gestão de projetos e de portfólio. O SEG surgiu com as mesmas características, porém com uma abordagem integradora, visando executar o ciclo completo da gestão de projetos e promovendo uma visão sistêmica da gestão da organização. 
- Ciência e Tecnologia

O Brasil, atualmente, se encontra na busca do terceiro objetivo do conjunto de instituições formadoras do SNI, citado por Ferreira, para uma política efetiva de desenvolvimento nacional. $O$ terceiro objetivo da política de C\&T é relativa ao desenvolvimento científico, ou seja, essa política resulta em desenvolvimento e fortalecimento da capacidade de pesquisa e a absorção de novos conhecimentos. Para que ela ocorra é necessário que haja um corpo de pesquisadores e técnicos capacitados, condições institucionais de treinamento e absorção profissional de especialistas. Além disso, é importante a integração entre universidades e centros de pesquisa visando maior exploração do conhecimento.

Prova de que o país está em busca do desenvolvimento científico, são as diretrizes do Plano Plurianual das Atividades do Governo Federal, nos quais encontram-se programas que buscam ampliar a competitividade e a sustentabilidade do agronegócio, além do desenvolvimento de agroenergia. Para alcançar seus objetivos, o Governo Federal incentiva a formação de parcerias entre universidades, centros de pesquisa e organizações públicas e privadas, visando a geração de inovação e a difusão do conhecimento. Um exemplo disso é o projeto Criando ferramentas para garantir a sanidade de produtos agrícolas, que faz parte da carteira de projetos do Macroprograma 1 da Embrapa. Esse projeto busca garantir a sanidade dos produtos agrícolas, visando a segurança alimentar, a melhoria na produtividade e na qualidade do produto. Esse projeto é desenvolvido por uma equipe com 63 doutores, 24 mestres e 40 colaboradores, tendo como parceiras o Departamento de Agricultura dos Estados Unidos (USDA Forest Service-Fort Collins), Universidade de Viçosa, Universidade de Brasília, Universidade Federal de Roraima, Universidade Federal do Paraná e o Ministério da Agricultura, Pecuária e Abastecimento; além, é claro, da Embrapa. Outro exemplo, é o projeto Tecnologias de obtenção de biodiesel, que também faz parte da carteira de projetos integrantes do Macroprograma 1 da Embrapa. Esse projeto busca novas matérias-primas para a extração do biodiesel, além da busca por novas formas de plantio, de adubação e controle de pragas. O projeto é desenvolvido contando com 15 centros de pesquisa Embrapa, nove universidades, cinco institutos e uma empresa privada, e envolve 155 pesquisadores.

Assim, fica claro que o investimento em pesquisa e em pesquisadores capacitados está cada vez maior, tanto que, hoje, a pesquisa agropecuária brasileira 
é reconhecida internacionalmente pela sua excelência, e é responsável por proporcionar mudanças econômicas e sociais significativas para país.

- Sistema Nacional de Inovação

O SNI é uma rede de instituições, tanto públicas quanto privadas, cujas atividades e interações iniciam, importam, modificam e difundem novas tecnologias. Em outras palavras, é a capacidade de um país de fomentar políticas de C\&T e de criar entidades com capacidade de implementá-las.

Tendo em vista esse conceito, a Embrapa é um dos mais importantes órgãos do Governo Federal ligado a pesquisa e inovação. Ela foi criada com o intuito de implementar um novo modelo de pesquisa agropecuária no país, já que a agricultura e a pecuária eram os principais produtos da economia brasileira na época de sua criação, em 1970. Atualmente, a Embrapa além de atuar em projetos de pesquisa de áreas consideradas estratégicas pelo Governo Federal, tais como a sustentabilidade e a competitividade dos produtos agropecuários, ela também possui projetos de pesquisa em áreas tidas como tendências consolidadas, tais como segurança energética, agroenergia e uso sustentável dos recursos naturais.

O sucesso obtido nos projetos de pesquisa é resultado de uma atuação interativa entre a Embrapa, universidades, centros de pesquisa, empresas públicas e privadas, e outros órgãos do Governo Federal, tais como o Ministério da Ciência e Tecnologia e o Ministério da Agricultura, Pecuária e Abastecimento. Hoje, a Embrapa possui parcerias até em outros países, o que colabora para a excelência dos pesquisadores e dos projetos de pesquisa, além de facilitar a troca de conhecimentos, variável essencial no processo de inovação.

Devido a esses esforços, o setor agropecuário brasileiro é altamente eficiente e competitivo no mercado internacional. O domínio tecnológico em ambiente tropical obtido durante todos esses anos de pesquisa proporciona ganhos sociais, econômicos, ambientais, científico e tecnológico para o país.

- Gestão de Pesquisa e Desenvolvimento (P\&D)

- Modelo de gestão

O modelo de gestão da Embrapa, sistematizado por meio do SEG, possui como base o modelo integrador de inovação tecnológica em organizações de P\&D. Esse modelo propõe que as características das equipes de pesquisa, juntamente 
com os recursos financeiros e materiais são insumos do processo de pesquisa e desenvolvimento, desencadeando o processo de inovação. Esse é influenciado pelas práticas de gestão da organização e pelo sistema de inovação no qual está inserido.

$\mathrm{Na}$ Embrapa, o modelo adotado busca uma visão sistêmica da gestão da organização. Isso é importante para que se possa executar o ciclo completo de gestão das atividades de pesquisa e desenvolvimento, sem deixar de cumprir os objetivos estratégicos da empresa. Além disso, esse modelo dota a empresa de maior flexibilidade, permitindo que sejam feitas correções de rumos em função de mudanças no ambiente. Outro fator importante, é que esse modelo permite o compartilhamento de recursos, de competências humanas e de infra-estrutura interna e de parceiros.

Assim, a geração de novos produtos, processos e serviços é incentivada pela própria cultura da empresa, já que está é essencialmente voltada para o ramo de pesquisa e desenvolvimento. Além disso, a empresa busca a motivação de seus pesquisadores por meio de programas de capacitação e incentivos para atrair e reter talentos, por meio de planos de carreiras e pelos níveis salariais adotados.

Seus projetos de pesquisa abrangem desde a geração de inovações até a sua transferência, para a efetiva utilização da tecnologia, visando cumprir o ciclo completo de inovação. Um fato importante é que na Embrapa, o conhecimento gerado pelas pesquisas é muito valioso, mesmo quando o projeto de pesquisa não obtém sucesso. Essa é importante fonte de sustentabilidade da aprendizagem organizacional.

- Processo de inovação

O modelo integrador é dividido em 5 etapas: identificação da demanda, proposta do projeto com a solução do problema detectado, execução do projeto, validação do projeto e a transferência da tecnologia gerada.

O SEG contempla todas as etapas propostas pelo modelo integrador, já que seu propósito é abranger todas as etapas do ciclo completo de gestão de projetos. Assim, comparando as fases do modelo integrador com o SEG, temos as seguintes conclusões resumidas no quadro 4. 


\begin{tabular}{|c|c|}
\hline Modelo Integrador & Sistema Embrapa de Gestão (SEG) \\
\hline $\begin{array}{l}\text { Etapa 1: Identificação de uma } \\
\text { necessidade ou demanda tecnológica. }\end{array}$ & $\begin{array}{l}\text { Etapa 1: Elaboração das diretrizes e } \\
\text { metas institucionais com base no PDE, } \\
\text { PDU e nos estudos prospectivos. Há } \\
\text { também a negociação dos recursos } \\
\text { financeiros, a definição das metas } \\
\text { técnicas e a iniciação do procedimento } \\
\text { de indução de projetos. }\end{array}$ \\
\hline $\begin{array}{l}\text { Etapa 2: Apresentação do projeto com a } \\
\text { proposta de solução do problema. }\end{array}$ & $\begin{array}{l}\text { Etapa 2: Elaboração das propostas e } \\
\text { pré-propostas de projetos pelas equipes } \\
\text { dos macroprogramas. }\end{array}$ \\
\hline Etapa 3: Produção do protótipo & $\begin{array}{l}\text { Etapa 3: As propostas de projetos que } \\
\text { foram aprovados, seguem para } \\
\text { execução nas } \\
\text { Descentralizadas. }\end{array}$ \\
\hline Etapa 4: Validação do protótipo & $\begin{array}{l}\text { Etapa 4: Avaliação final do projeto, } \\
\text { identificando os resultados obtidos e as } \\
\text { metas alcançadas. }\end{array}$ \\
\hline $\begin{array}{l}\text { Etapa 5: Transferência da inovação } \\
\text { desenvolvida }\end{array}$ & Etapa 5: Transferência da tecnologia \\
\hline
\end{tabular}

Quadro 4: Comparação das etapas do modelo integrador com o SEG

- Gestão de portfólio de projetos

A gestão de projetos da Embrapa é feita baseada na formação de uma carteira de projetos, a qual deve garantir o balanço estratégico dos objetivos traçados pelo Plano Diretor Embrapa (PDE). Para uma boa gestão de um portfólio de projetos, ou carteira de projetos, Rabechini, Maximiano e Martins (2005) propõe um modelo dividido em seis etapas, que podem ser resumidas como: identificação de critérios para a seleção de projetos, formação da lista de projetos, avaliação da lista de projetos, formação da carteira de projetos a serem executados, administração do portfólio de projetos e revisão e controle dos projetos.

$\mathrm{Na}$ Embrapa, a gestão de projetos possui todas essas fases. Cada Macroprograma possui sua própria carteira de projetos a serem executados e em 
execução. A cada semestre, são feitas novas seleções de projetos para integrar a carteira de projetos visando alcançar os objetivos institucionais traçados pelo PDE.

O quadro 5, resume a comparação entre o modelo proposto por Rabechini e o modelo adotado na Embrapa.

\begin{tabular}{|c|c|}
\hline $\begin{array}{c}\text { Modelo de gestão de portfólio } \\
\text { proposto por Rabechini, Maximiano e } \\
\text { Martins (2005) }\end{array}$ & $\begin{array}{c}\text { Modelo de gestão da carteira de } \\
\text { projetos da Embrapa }\end{array}$ \\
\hline $\begin{array}{l}\text { Etapa 1: identificação dos critérios de } \\
\text { seleção dos projetos }\end{array}$ & $\begin{array}{l}\text { Etapa 1: publicação da Chamada } \\
\text { contendo as linhas temáticas de } \\
\text { pesquisa e os critérios que serão } \\
\text { avaliados }\end{array}$ \\
\hline $\begin{array}{l}\text { Etapa 2: formação da lista de projetos } \\
\text { que poderão formar a carteira }\end{array}$ & $\begin{array}{l}\text { Etapa 2: as propostas de projetos são } \\
\text { encaminhadas para o Comitê Técnico. }\end{array}$ \\
\hline $\begin{array}{l}\text { Etapa 3: avaliação dos projetos da lista, } \\
\text { visando a sua priorização }\end{array}$ & $\begin{array}{l}\text { Etapa 3: as propostas que passaram na } \\
\text { fase anterior, são avaliadas por } \\
\text { consultores de fora da Embrapa sob o } \\
\text { mérito técnico. Em seguida, as propostas } \\
\text { que obtiveram sucesso, são } \\
\text { encaminhadas para a avaliação de } \\
\text { mérito estratégico feito pelo Comitê } \\
\text { Gestor da Programação (CGP) }\end{array}$ \\
\hline $\begin{array}{l}\text { Etapa 4: os projetos escolhidos formam } \\
\text { a carteira de projetos a serem } \\
\text { executados }\end{array}$ & $\begin{array}{l}\text { Etapa 4: os projetos aprovados pelo } \\
\text { CGP são homologados e formarão a } \\
\text { carteira de projetos a serem executados } \\
\text { na Embrapa }\end{array}$ \\
\hline $\begin{array}{l}\text { Etapa 5: administração da carteira de } \\
\text { projetos (recursos financeiros, materiais } \\
\text { e humanos) }\end{array}$ & $\begin{array}{l}\text { Etapa 5: o acompanhamento dos } \\
\text { projetos é feito pelo líder do projeto }\end{array}$ \\
\hline Etapa 6: revisão e controle do projeto & $\begin{array}{l}\text { Etapa 6: periodicamente, é enviado } \\
\text { relatórios com os resultados de cada } \\
\text { projeto. }\end{array}$ \\
\hline
\end{tabular}

Quadro 5 - Comparação entre o modelo de gestão de portfólio de Rabechini, Maximiano e Martins e o modelo de gestão de carteira de projetos da Embrapa 
O modelo de gestão de portfólio proposto por Rabechini, Maximiano e Martins (2005) ressalta que é importante que na etapa de avaliação de projetos (etapa 3), a avaliação seja feita por um comitê de pessoas credenciadas e que levem em consideração aspectos táticos e estratégicos das projetos. Esses aspectos são considerados na Embrapa, já que a avaliação é feita por comitês e por consultores ad-hoc credenciados, que avaliam critérios relativos ao mérito técnico e ao mérito estratégico, visando uma seleção mais rigorosa das propostas de projetos.

- Método de seleção de projetos

A seleção dos projetos de P\&D da Embrapa é feita utilizando-se técnicas tanto qualitativas quanto quantitativas. Com essa mistura, o processo ganha maior confiabilidade, pois opiniões diversas são consideradas. Assim, no processo de seleção são usadas técnicas de pontuação e de ordenamento.

A técnica de pontuação consiste em atribuir pontuação aos critérios préestabelecidos. Isso ocorre na etapa de mérito estratégico, em que são estabelecidos escores indicativos de relevância para os critérios estabelecidos, que são: qualidade técnica, alinhamento aos objetivos estratégicos, riscos associados à execução do projeto, avanço técnico-científico proposto e ganhos previstos para os clientes e para os beneficiários.

Já a técnica de ordenamento, que consiste em classificar os projetos mediante comparação, sendo assim bastante subjetivo, ocorre na etapa inicial de seleção dos projetos feita pelos Comitês Técnicos, em que são avaliados se as propostas podem ou não passar para a próxima etapa, no caso, a avaliação de mérito técnico.

Além disso, é utilizada no processo de seleção, a avaliação de especialistas na área, mas que não trabalham na empresa. Isso faz com que sejam evitadas decisões tendenciosas na priorização das propostas. A essa técnica, Morais F. e Weinberg (2002) dão o nome de pesquisa de opinião com especialistas.

Assim, o método de seleção de projetos de P\&D utilizado pela Embrapa é um misto de várias técnicas de seleção, o que faz com que o processo possua alta credibilidade, além de possibilitar a documentação do processo de seleção. 
- Avaliação do método de seleção de projetos

O método de seleção de projetos de P\&D utilizado na Embrapa, por considerar aspectos tanto qualitativos quanto quantitativos, possui várias vantagens. Dentre elas, podemos citar a redução de decisões tendenciosas, já que considera opiniões subjetivas e objetivas, a documentação do processo de seleção, já que este é feito em várias etapas e consolidado em relatórios; e a redução dos fatores de incerteza que estão intrinsecamente presentes nas atividades de P\&D, tais como risco, cenários de incerteza e o comprometimento de recursos financeiros e humanos, posto que esses são itens avaliados em todas as etapas do processo e por diferentes comitês.

Quanto a desvantagem do método, podemos citar o aspecto tempo. Por passar por várias etapas e por depender de resultados avaliados por diferentes pessoas, sendo essas internas e externas a empresa, o processo de seleção é demorado.

- Avaliação de resultados

A bem sucedida gestão de projetos da Embrapa possibilita a execução de projetos em diferentes áreas de interesse, todas essas sendo importantes para 0 avanço científico e para a melhoria social e econômica do país.

Devido às pesquisas feitas pela Embrapa e suas parceiras, o Brasil se tornou líder em agricultura tropical, solucionou problemas de abastecimento interno e fez com que o país se inserisse no mercado internacional de alimentos, fibras e de energia renovável. Além disso, as tecnologias geradas proporcionam diferentes tipos de impacto para o país, dentre os principais estão incremento da produtividade, redução de custos, agregação de valor aos produtos, incremento de produção em novas áreas, ou seja, possibilidade de produzir em áreas anteriormente impróprias ao cultivo devido à deficiência das tecnologias tradicionais; e a geração de empregos.

Segundo o Balanço Social da Embrapa de 2007, houve um aumento de $86 \%$ da produtividade da terra no período de 1970 a 2006, e graças ao desenvolvimento tecnológico alcançado houve a preservação dos recursos naturais, sendo evitado o sacrifício de enormes áreas florestais. Além disso, foram gerados 114.965 (cento e quatorze mil, novecentos e sessenta e cinco) empregos devido às tecnologias geradas e transferidas pela Embrapa, juntamente com seus parceiros e 
colaboradores. Outro ponto importante é que a relação entre lucro social e receita operacional da Embrapa foi de 13,36 para 1 em 2007, ou seja, para cada um real investido, foi gerado um lucro de 13,36 reais.

Os benefícios trazidos pelas pesquisas são reconhecidos pela sociedade. No ano de 2007, a Embrapa recebeu vários prêmios, dentre os quais estão: Prêmio Aberje Centro-Oeste, Prêmios Finep de Inovação Tecnológica e o Prêmio GRM/ACP. Todos esses aspectos mostram que investir em pesquisa agropecuária, agroenergética e florestal é muito importante, além de ser um ótimo negócio para o país. 


\section{CONSIDERAÇÕES FINAIS}

O presente estudo buscou apresentar aspectos sobre a importância das atividades de pesquisa e desenvolvimento (P\&D) para o crescimento do país. Como abordado ao longo deste trabalho, a inovação é o principal meio das empresas adquirirem vantagem competitiva e se manterem no mercado altamente competitivo que temos atualmente. Porém, a geração de inovação, não é algo simples, ela envolve uma série de fatores.

A inovação, hoje, é vista como um processo baseado no conhecimento e que possui várias etapas. Assim, a geração de inovação envolve um processo de busca, seleção, implementação e avaliação. Visando gerenciar esse processo de inovação, vários modelos foram propostos, evoluindo desde o modelo linear até o modelo sistêmico, o qual propõe que as empresas não inovam isoladamente.

$\mathrm{Na}$ atual Era do Aprendizado, a transferência de conhecimento é extremamente importante, já que ele é o principal impulsionador do processo de inovação. Para que ocorra essa troca de conhecimento, é necessária a interação entre universidades, centros de pesquisa, empresas públicas e privadas, que ocorre dentro do contexto do chamado Sistema Nacional de Inovação (SNI).

De forma mais abrangente, o SNI pode ser descrito como a capacidade do país de fomentar políticas de ciência e tecnologia e de criar mecanismos para implementá-las. Portanto, quanto mais evoluído for o SNI, maior é a capacidade de gerar inovações e, consequentemente, maior será o desenvolvimento do país.

A atividade de pesquisa e desenvolvimento é parte fundamental do processo de inovação tecnológica. Porém, para a chegada a essa etapa do processo, etapas anteriores devem ter sido contempladas. Buscando gerenciar melhor a inovação, modelos de inovação tecnológica dentro das organizações de P\&D foram propostos por diversos autores contemplando as diversas etapas do processo de geração de inovações. Após vários estudos, chegou-se a conclusão de que a forma mais eficiente de gerenciar a inovação é por meio da gestão de um portfólio de projetos.

A gestão de um portfólio de projetos de P\&D proporciona a empresa a redução de riscos e o aumento de temas pesquisados, criando maiores chances de gerar inovações. Porém, fator crucial dessa gestão é a escolha dos projetos que irão compor essa carteira ou portfólio. Caso sejam escolhidos projetos de P\&D errados, 
haverá o comprometimento de recursos, humanos e materiais, por determinado tempo e sem a geração de nenhuma vantagem para a empresa. Por isso a importância da etapa de seleção de projetos.

A seleção de projetos de P\&D é dificultada pela falta de dados sobre 0 assunto, tais como riscos, cenários de incerteza e comprometimento de recursos por longos períodos de tempos. Tentando minimizar a falta desses dados, existem vários métodos de seleção de projetos, desde totalmente quantitativos até os totalmente qualitativos.

Sendo o objetivo principal dessa pesquisa entender o processo de seleção de projetos de pesquisa e desenvolvimento (P\&D), a organização escolhida para o estudo de caso foi a Empresa Brasileira de Pesquisa Agropecuária (Embrapa), um dos principais órgãos do Governo Federal que trabalham com pesquisa e desenvolvimento. Suas pesquisas proporcionaram ao país um sistema produtivo altamente competitivo e de qualidade, e o patamar de referência para a agropecuária de clima tropical.

Sua gestão da inovação é feita por meio da formação de uma carteira de projetos, distribuídos de acordo com seis diferentes temas formadores de seis macroprogramas. Os temas pesquisados são: grandes desafios nacionais, competitividade e sustentabilidade setorial, desenvolvimento tecnológico incremental do agronegócio, transferência de tecnologia e comunicação empresarial, desenvolvimento institucional, e apoio ao desenvolvimento da agricultura familiar e à sustentabilidade do meio rural.

Pela Embrapa contemplar todas as etapas do processo de geração de inovações, existem ainda vários temas que não foram explorados nessa pesquisa, posto que esta foi restrita ao entendimento do processo de seleção de projetos de P\&D. Novas pesquisas podem ser feitas procurando entender o processo de transferência de tecnologias feita pela Embrapa, etapa de extrema importância para a efetiva aplicabilidade da inovação gerada.

Pode ser feita ainda pesquisa buscando analisar de forma mais aprofundada o papel da Embrapa para a evolução da ciência e tecnologia e para o crescimento do país. 


\section{REFERÊNCIAS}

BARBIERI, José Carlos; SIMANTOB, Moysés Alberto. Organizações Inovadoras Sustentáveis - São Paulo : Atlas, 2007.

EMBRAPA. Balanço social da pesquisa agropecuária brasileira. - Brasília, DF : Embrapa, Assessoria de Comunicação Social: Secretaria de Gestão e Estratégia, 2008.

EMBRAPA. Características e gestão de macroprogramas. Manual do sistema Embrapa de gestão - Brasília, DF : Embrapa, 2004.

EMBRAPA. Características e gestão do projeto. Manual do sistema Embrapa de gestão - Brasília, DF : Embrapa, 2002.

EMBRAPA. Ciência, gestão e inovação: dimensões da agricultura tropical. Brasília, DF : Embrapa - Assessoria de Comunicação Social, 2008.

EMBRAPA. Chamada 02/2009 - Brasília, DF : Embrapa, 2009.

EMBRAPA. Chamada 04/2009 - Brasília, DF : Embrapa, 2009.

EMBRAPA. Fundamentos, estrutura e funcionamento do Sistema Embrapa de Gestão (SEG). Manual do sistema Embrapa de gestão - Brasília, DF : Embrapa, 2004.

EMBRAPA. Programa nacional de pesquisa e desenvolvimento da agropecuária - Pronapa 2008, Brasília : DF, Embrapa

EMBRAPA. V Plano Diretor Embrapa 2008-2011-2023 - Brasília, DF : Embrapa, 2008.

FLICK, Uwe. Uma introdução à pesquisa qualitativa, trad. Sandra Netz. - 2.ed. Porto Alegre : Bookman, 2004.

LEMOS, Cristina. Inovação na era do conhecimento - Revista Parcerias Estratégicas, n. 8, p. 157-178, maio/2000.

LIMA, Suzana Maria Valle; CASTRO, Antônio Maria Gomes; ANDRADE, Jairo Eduardo Borges; CARVALHO, José Ruy Porto. Inovação e gestão tecnológica em organizações de P\&D: um modelo integrador - Cadernos de Ciência \& Tecnologia, Brasília, v.21, n.1, p. 83-103, jan./abr. 2004.

MATTOS, João Roberto Loureiro de; GUIMARÃES, Leonam dos Santos. Gestão da Tecnologia e Inovação - São Paulo : Saraiva, 2005 , p. 22-24.

MORAIS FILHO, Cassiano A.; WEINBERG, Georg Michael Lennart. Seleção de projetos de P\&D: uma abordagem prática - Revista de Administração, São Paulo, v.37, n.1, p. 85-92, jan./mar. 2002. 
MOREIRA, Daniel Augusto; QUEIROZ, Ana Carolina S.. Inovação organizacional e tecnológica - São Paulo: Thomson Learnig, 2007.

RABECHINI, Roque Jr; MAXIMIANO, Antonio César Amaru; MARTINS, Vergilio Antonio. A adoção de gerenciamento de portfólio como uma alternativa gerencial: o caso de uma prestadora de serviço de interconexão eletrônica Revista Produção, v.15, n.3, p. 416-433, set./dez. 2005.

ROESCH, Sylvia Maria Azevedo. Projetos de estágio e de pesquisa em administração: guia para estágios, trabalhos de conclusão, dissertações e estudos de caso; colaboração Grace Vieira Becker, Maria Ivone de Mello - 3. Ed. São Paulo : Atlas, 2005.

TIDD, Joe; BESSANT, John; PAVITT, Keith. Gestão da Inovação, trad. Elizamari Rodrigues Becker ... [ et all]. - 3. Ed. Porto Alegre : Bookman, 2008.

VIOTTI, Eduardo Baumgratz; MACEDO, Mariano de Matos. Indicadores de ciência, tecnologia e inovação no Brasil - Campinas, SP : Editora da Unicamp, 2003.

YIN, Robert K., Estudo de Caso - Planejamento e Métodos, trad. Daniel Grassi. 3. Ed. Porto Alegre: Bookman, 2005.

ZOUAIN, Deborah Morais. Gestão de instituições de pesquisa - Rio de Janeiro : Editora FGV, 2001. 


\title{
ANEXO \\ Anexo A: Chamada do Macroprograma 5
}

\author{
Embrapa \\ SEG - Sistema Embrapa de Gestão \\ Chamada 04/2009 \\ Macroprograma 5
}

\section{Chamada}

A Empresa Brasileira de Pesquisa Agropecuária, no âmbito de sua programação ordinaria estará acolhendo propostas de Projetos de Desenvolvimento Institucional, para o Macroprograma 5, visando:

- Consolidar e atualizar os instrumentos de gestão estratégica da Embrapa;

- Contribuir para o aumento da eficiência organizacional da Empresa, por meio do desenvolvimento de novos processos ou da melhoria incremental ou inovadora dos processos técnicos, gerenciais e administrativos;

- Promover o desenvolvimento institucional da organizaçăo e a utilizaçâo plena do potencial das competencias humanas da Embrapa;

- Fomentar a gestâo da informaçâo e do conhecimento na Empresa:

- Estimular a articulação e a formaçào de parcerias entre as Unidades da Embrapa e outras instituiçốes de pesquisa.

\section{Elegibilidade Institucional:}

As propostas de projetos em Desenvolvimento institucional poderăo ser submetidas por analistas e pesquisadores, na qualidade de lider de projeto ou responsável por processo, do quadro regular da Embrapa, com vinculação empregaticia em qualquer de suas Unidades.

É permitida a participação, como parceiros externos, de outras instituiçóes com atuaçảo na área de Desenvolvimento Institucional, ou áreas correlatas, desde que satisfaçam os requisitos de competência institucional nos temas propostos para desenvolver as açôes gerenciais e as exigências legais pertinentes.

Em caso de aprovaçâo de propostas com a participação de parceiros externos, a Unidade proponente e $o$ líder do projeto deverâo seguir as instruçôes específicas que se encontram no formulário de proposta de projeto.

\section{Macroprograma e Linhas de Pesquisa:}

os projetos a serem elaborados, devem estar voltados para açōes institucionais inovadoras de caráter estratégico, que visem à criaçâo e/ou implantaçăo de um novo processo ou a melhoria significativa de processo existente, ou ainda, a adoção de estrutura, metodologias e procedimentos de projetos corporativos em execuçấo que 


\section{Embrapa}

contribuam para a melhoria e inovaçâo dos processos de gestăo, nas seguintes linhas temáticas:

- Deservolvimento, modernizaçào, validaçào e/ou implantaçáo de metodologias, procedimentos, mecanismos e sistemas para promoçâo da gestâo institucional da informação e do conhecimento;

- Fortalecimento da inteligência estratégica organizacional para assegurar a qualidade, a relevância e a efetividade das açōes de PDCt;

- Deservolvimento e aprimoramento dos sistemas de gestão, por meio da adoção de boas práticas e obtençăo de certificaçăo em institutos de credenciamento;

- Realização de estudos prospectivos para detecção de oportunidades de inovação;

- Desenvolvimento de novos processos ou da melhoria incremental ou inovadora dos processos estratégicos, gerenciais, técnicos e administrativos, visando o aumento da eficiência organizacional da Empresa;

LINHA ABERTA: O Macroprograma 5 oferece ainda a linha aberta contemplando projetos orientados para a análise e melhoria de processos estratégicos e corporativos, o desenvolvimento de conhecimentos, metodologias e práticas de gestäo inovadoras que visem o aumento da efetividade organizacional, atendendo aos concetos norteadores do Macroprograma 5.

? O Macroprograma 5 contará com a fase de carta consulta, obrigatoriamente, para a Inha aberta e opcionalmente para as demais linhas.

\section{Formato da Chamada:}

a. As propostas apresentadas deverâo estar em conformidade com os conceitos e norteadores estabelecidos no Manual do Sistema Embrapa de Gestâo - SEG, na norma: Caracteristicas e Funcionamento do Macroprograma 5: Desenvolvimento Institucional.

b. Ser elaboradas por meio do sistema informatizado - formulário de apresentaçäo de proposta versäo 2.0.0 Build.10 (InfoSEG), via Internet, disponibilizado no endereco:

hitps://intranetembrapa.bripesquisa desenvolvimento/segisetupfomulario-2-0-0$10 . z j p$, que utilizara ferramentas de autenticaçăo eletrónica de documentos e emissấo de recibos.

\section{Calendário}

Essa chamada será regida pelo seguinte calendário: 


\section{Embrapa}

Para inicio com cartas consulta

\begin{tabular}{|l|c|}
\hline Data limite para recebimento das cartas-consulta & Até 17 de abril de 2009 \\
\hline Resultado da Avaliação das cartas-consulta & Até 10 de julho de 2009 \\
\hline Recebimento das propostas & Até 18 de setembro de 2009 \\
\hline Resultado da aval lação final das propostas & Até 11 de Dezembro de 2009 \\
\hline Inicio provável da execução dos projetos aprovados & Abril 2010 \\
\hline
\end{tabular}

Para inicio com propostas

\begin{tabular}{|l|c|}
\hline Data limite para recebimento das propostas & Até 17 de abril de 2009 \\
\hline Resultado da Avaliação das propostas & Até 10 de julho de 2009 \\
\hline Inicio provável da execução dos projetos aprovados & Setembro de 2009 \\
\hline
\end{tabular}

\section{Recursos Totais, Indicativos de Orçamento e Duração dos Projetos}

- o total de recursos, a ser aplicado pela Embrapa nesta Chamada, é de RS 3.000.000,00 (três milhôes de reais) para um periodo indicativo de 36 meses, a partir de setembro de 2009.

- O valor indicativo para o orçamento anual dos projetos desse Chamada é da ordem de RS $150.000,00$ (cento e cinqüenta mil reais) por ano, com duração esperada de 36 meses. Os projetos desse Macroprograma poderão pleitear recursos para investimentos até o valor teto de RS $13.000,00$ (treze mil reais) ao ano, por projeto (limite de RS $39.000,00$ por projeto), desde que a natureza do mesmo justifique o uso desses recursos.

- As propostas devem prever no seu orçamento um percentual de até $15 \%$ do valor total do custeio destinado a cada Unidade participante, a titulo de custos adicionais de manutençăo que o projeto gerará para a Unidade (exceto parceiros extemos). $O$ valor correspondente aos $15 \%$ deverá ser inserido em Plano de Ação lGestão da proposta, no item material de consumo.

\section{Remessa das Propostas}

1. As cartas-consulta (opcional) e as propostas devem ser elaboradas e enviadas (após análise do CTICTS) por meio do sistema informatizado - fomulário de 


\section{Embrapa}

apresentaçăo de proposta versão 20.0 Buld.10 (InfoSEG), via Internet, disponibilizado no endereco:

https:/lintranet.embrapa.bripesquisa desenvolvimentolseg/setupformulario-2-0-010.zip que utilizará ferramentas de autenticaçăo eletrónica de documentos e emissäo de recibos. Antes de iniciar o preenchimento do formulário deve-se realizar o procedimento de atualizaçâo remota das regras e tabelas de domínio (ver Nota Técnica em:

https://intranet.embrapa.bripesquisa desenvolvimentolseginotatecnicaformulariopr oposta. od

2. Após o envio das propostas, o CTUCTS deve encaminhar ao DPD os recibos emitidos pelo Infoseg de todas as propostas submetidas pela UD, por meio de expediente formal assinado por um dos dirigentes da Unidade líder do projeto. $O$ encaminhamento dos recibos pelo CTVCTS será considerado como a autorização desta instância para a submissäo da proposta.

3. O sistema năo receberá propostas ou ateraçōes de qualquer natureza fora dos prazos estabelecidos.

\section{Exigências Adicionais}

Será ainda desqualificada a proposta que:

1. Atualizaçâo do Curriculum vitae há menos de 6 (seis) meses na Plataforma Lattes de Curriculo do CNPq - http://lattes.cnpq.br - do líder do projeto, obrigatoriamente, quando este for pesquisador; e preferencialmente, quando o líder ocupar outro enquadramento funcional.

2. Năo for encaminhado pelo comitê Técnico interno (CT), no caso de Unidades Descentralizadas e pelo Comitê Técnico da Sede (CTS), no caso das Unidades Centrais e Serviços Especiais, o recibo de envio da proposta gerado pelo infoseg.

\section{Critérios de Avaliação}

Uma vez que o Macroprograma 5 nâo contará com a fase de pré-proposta, as propostas encaminhadas que năo estiverem em conformidade com a chamada ou que apresentarem problemas com as planilhas orçamentárias serão automaticamente desabilitadas, não passando sequer pelas avaliaçóes quanto ao seu mérito técnico e ao seu mérito estratégico.

As propostas serăo avaliadas conforme critérios listados a seguir:

Conformidade com o Chamada:

- Adequação às linhas temáticas estabelecidas.

- Elegibilidade institucional do proponente e dos participantes.

- Conformidade aos conceitos do Macroprograma 5, expressos na Norma: Caracteristicas e Gestão do Macroprograma 5 - Desenvolvimento Institucional (037.01.08.01.5.008).

- Atualizaçào do Curriculum vitae há menos de 6 (seis) meses na Plataforma Lattes de Curniculo do CNPq - http://lattes.cnpq.br - do tider do projeto, 


\section{Embrapa}

obrigatoriamente, quando este for pesquisador, e preferencialmente, quando o lider ocupar outro enquadramento funcional.

\section{Mérito Técnico - Qualidade da Proposta:}

- Clareza na definição dos objetivos, das metas e das estratégias;

- Coerência entre as metas institucionais e as metas técnicas da Empresa/Unidade;

- Descrição dos impactos e dos resultados esperados e obtidos, bem como a demonstração do mérito técnico do projeto;

- Qualificaçâo das instituiçōes integrantes, da equipe e dos parceiros envolvidos;

- Adequaçâo ao sistema de gestảo da Empresa e aos arranjos sobre Propriedade Intelectual;

- Viabilidade de transferência dos resultados para toda a Empresa;

- Adequaçâo da proposta orçamentária e da duraçăo do projeto

\section{Mérito Estratégico:}

A avaliaçâo de mérito estratégico das cartas consulta e propostas é realizada pelo Comitê Gestor da Programaçẩo em suas reuniōes ordinárias. Esta avaliaçăo tem como referência fundamental os objetivos e diretrizes estratégicos [gerais e especificos] do V Plano Diretor da Embrapa [V PDE]. Com ela procura-se determinar a contribuiçăo de cada proposta de projeto, em relaçâo à carteira de projetos em execuçâo na Embrapa, para:

a. o cumprimento das metas institucionais da Empresa;

b. Gerar impactos em relaçâo à estratégia institucional; assim como,

c. Avaliar o custo do projeto em relaçăo aos benefícios institucionais esperados.

Cada carta consulta e proposta de projeto é avaliada individualmente, considerando-se a programaçào que está sendo executada e os objetivos estratégicos estabelecidos no $V$ PDE, determinando-se, por meio de escores indicativos de relevância, o grau em que cada proposta de projeto contribuirá para - alcance de objetivos estratégicos do V PDE da Embrapa e/ou de temas emergentes [que por sua vez sâo definidos pela DE, Comitê Gestor de Estratégica, ou pelo Comitê Gestor da Programação da Embrapa], avaliando-se, isoladamente e em conjunto, os seguintes componentes:
a. Qualidade técnica;
b. Alinhamento às diretrizes estratégicas;
c. Riscos associados à execucăo do projeto;
d. Ganho potencial para melhoria da gestão;
e. Ganhos previstos para os clientes/beneficiários. 